NIST NCSTAR 1-3A

Federal Building and Fire Safety Investigation of the World Trade Center Disaster

\title{
Contemporaneous Structural Steel Specifications
}

William E. Luecke

Thomas A. Siewert

Frank W. Gayle 

NIST NCSTAR 1-3A

\section{Federal Building and Fire Safety Investigation of the World Trade Center Disaster}

\section{Contemporaneous Structural Steel Specifications}

William E. Luecke

Thomas A. Siewert

Frank W. Gayle

Materials Science and Engineering Laboratory

National Institute of Standards and Technology

September 2005

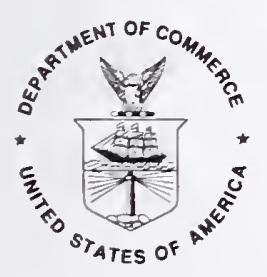

U.S. Department of Commerce

Carlos M. Gutierrez, Secretary

Technology Administration

Michelle O'Neill, Acting Under Secretary for Technology

National Institute of Standards and Technology

William Jeffrey, Director 


\section{Disclaimer No. 1}

Certain commercial entities, equipment, products, or materials are identified in this document in order to describe a procedure or concept adequately or to trace the history of the procedures and practices used. Such identification is not intended to imply recommendation, endorsement, or implication that the entities, products, materials, or equipment are necessarily the best available for the purpose. Nor does such identification imply a finding of fault or negligence by the National Institute of Standards and Technology.

\section{Disclaimer No. 2}

The policy of NIST is to use the International System of Units (metric units) in all publications. In this document, however, units are presented in metric units or the inch-pound system, whichever is prevalent in the discipline.

\section{Disclaimer No. 3}

Pursuant to section 7 of the National Construction Safety Team Act, the NIST Director has determined that certain evidence received by NIST in the course of this Investigation is "voluntarily provided safety-related information" that is "not directly related to the building failure being investigated" and that "disclosure of that information would inhibit the voluntary provision of that type of information" (15 USC 7306c).

In addition, a substantial portion of the evidence collected by NIST in the course of the Investigation has been provided to NIST under nondisclosure agreements.

\section{Disclaimer No. 4}

NIST takes no position as to whether the design or construction of a WTC building was compliant with any code since, due to the destruction of the WTC buildings, NIST could not verify the actual (or as-built) construction, the properties and condition of the materials used, or changes to the original construction made over the life of the buildings. In addition, NIST could not verify the interpretations of codes used by applicable authorities in determining compliance when implementing building codes. Where an Investigation report states whether a system was designed or installed as required by a code provision, NIST has documentary or anecdotal evidence indicating whether the requirement was met, or NIST has independently conducted tests or analyses indicating whether the requirement was met.

\section{Use in Legal Proceedings}

No part of any report resulting from a NIST investigation into a structural failure or from an investigation under the National Construction Safety Team Act may be used in any suit or action for damages arising out of any matter mentioned in such report (15 USC 281a; as amended by P.L. 107-231).

National Institute of Standards and Technology National Construction Safety Team Act Report 1-3A Natl. Inst. Stand. Technol. Natl. Constr. Sfty. Tm. Act Rpt. 1-3A, 86 pages (September 2005) CODEN: NSPUE2

\section{U.S. GOVERNMENT PRINTING OFFICE WASHINGTON: 2005}

For sale by the Superintendent of Documents, U.S. Government Printing Office Internet: bookstore.gpo.gov — Phone: (202) 512-1800 — Fax: (202) 512-2250 Mail: Stop SSOP, Washington, DC 20402-0001 


\section{ABSTRACT}

This report reviews the contemporaneous (1960s era) steel and welding standards used to construct the 110-story World Trade Center (WTC) towers. It describes the major structural elements in the towers and the many grades of steels relevant to the WTC investigation. Although ASTM International structural steel standards have evolved since the towers were built, the changes are generally minor and not significant for estimating mechanical properties.

Keywords: Steel, standards, tower structural design, World Trade Center. 
This page intentionally left blank. 


\section{TABLE OF CONTENTS}

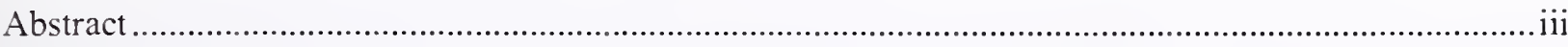

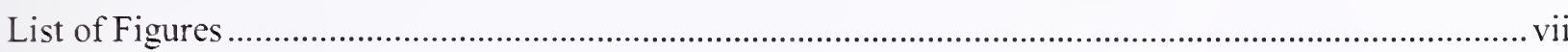

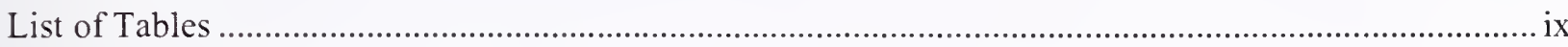

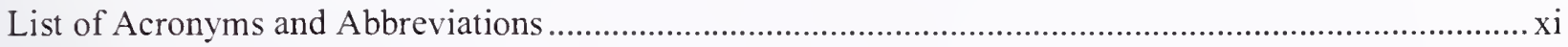

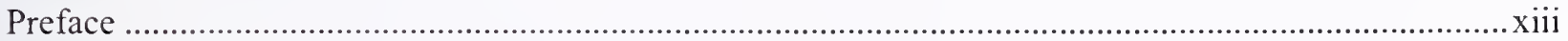

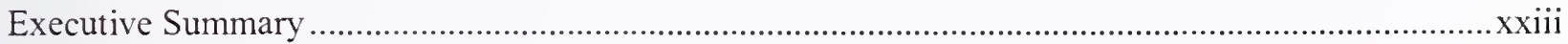

\section{Chapter 1}

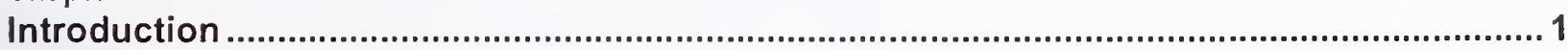

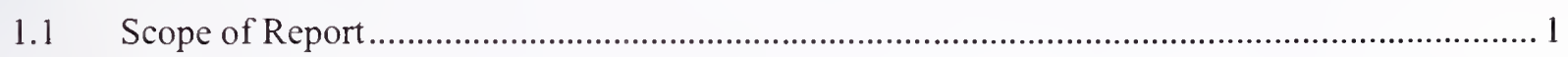

1.2 Specification of Steel Grades (minimum yield strength) .................................................... 2

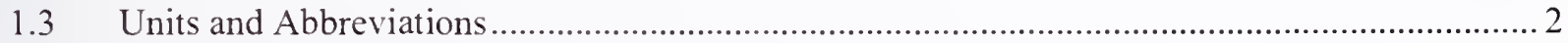

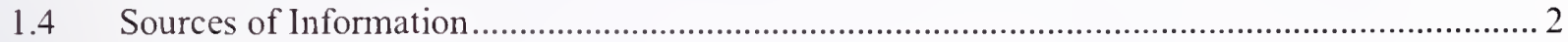

\section{Chapter 2}

Tower Design - Structural Steel Documents .........................................................5

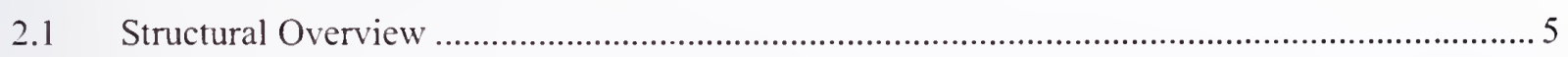

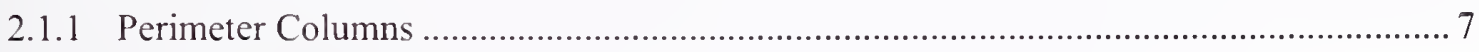

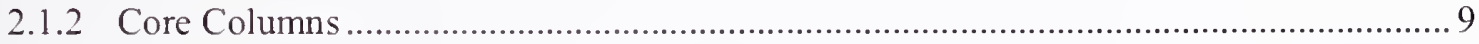

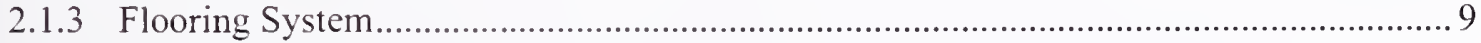

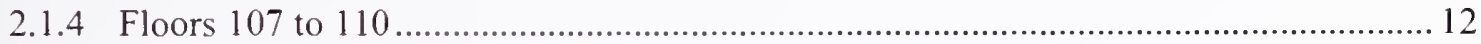

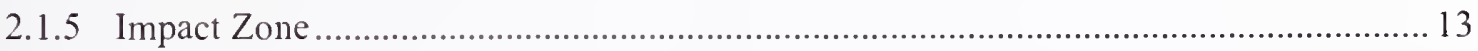

2.1.6 Floors Involved in Post-Impact Fires.......................................................... 14

\section{Chapter 3}

Contemporaneous Steel Specifications ............................................................... 15

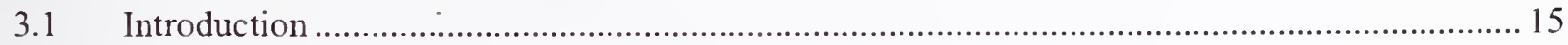

3.2 Standards Called for in the Steel Contracts ................................................................ 15

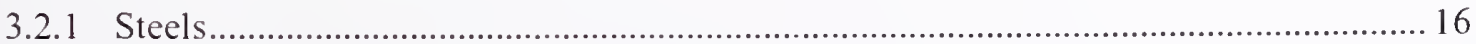

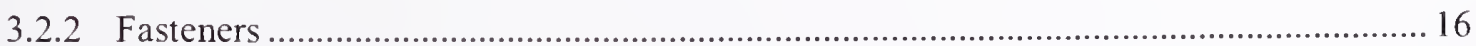

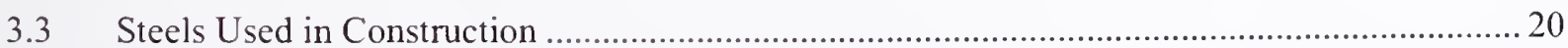

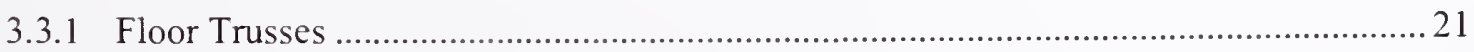

3.3.2 Perimeter Columns and Spandrels ................................................................ 22

3.3.3 Core (Welded Box Columns) .............................................................................. 27 


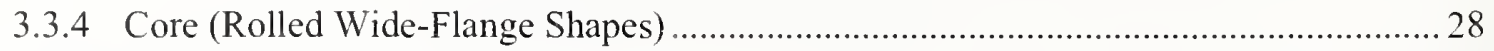

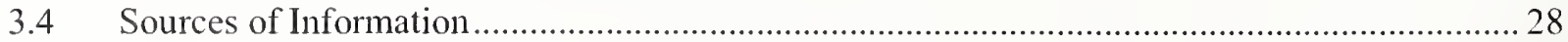

\section{Chapter 4}

Contemporaneous Construction Specifications

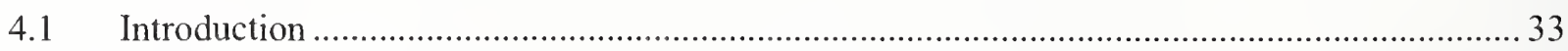

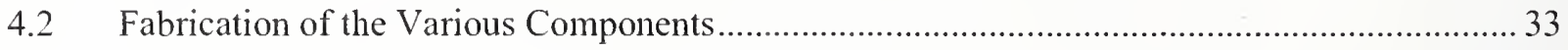

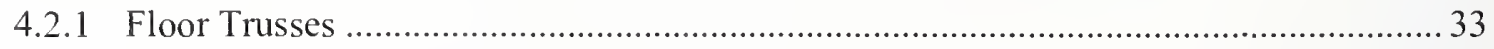

4.2.2 Exterior Wall Columns and Spandrels................................................................. 33

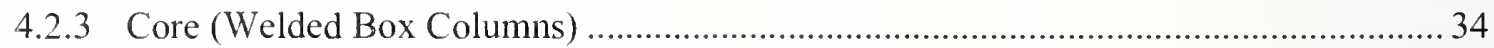

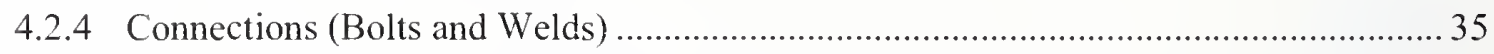

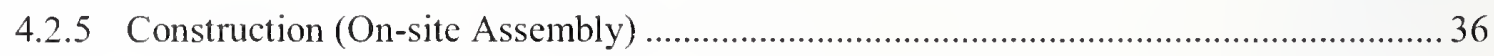

Chapter 5

References.

5.1 References from Publicly Available Sources ................................................................. 39

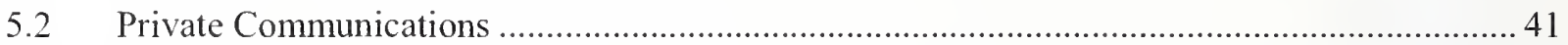

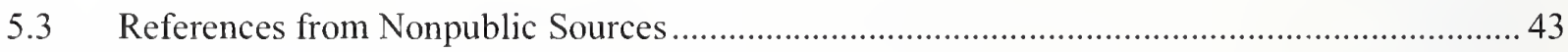

\section{Appendix A}

Steel Companies Involved in the World Trade Center

Appendix B

Notes on ASTM Standards for Structural Steel 


\section{LIST OF FIGURES}

Figure $\mathrm{P}-1$. The eight projects in the federal building and fire safety investigation of the WTC disaster. XV

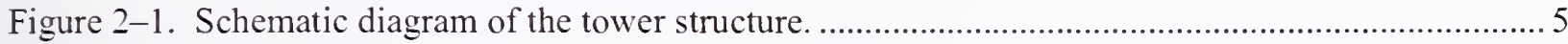

Figure 2-2. WTC tower floor plan and column numbers. ........................................................ 6

Figure 2-3. Cross-section of perimeter columns; sections with and without spandrels. ......................... 7

Figure 2-4. Characteristic perimeter column panel consisting of three full columns connected by three spandrels.

Figure 2-5. Partial elevation of exterior bearing-wall frame showing exterior wall module construction. Highlighted panel is three stories tall $(36 \mathrm{ft})$ and spans four floors. Distance between panels has been exaggerated. . 8

Figure 2-6. Typical welded box members and rolled wide flange shapes used for core columns

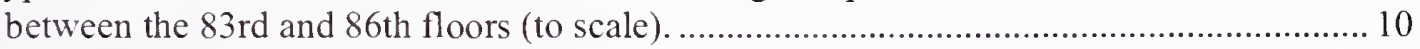

Figure 2-7. Core column layout in WTC towers..................................................................... 10

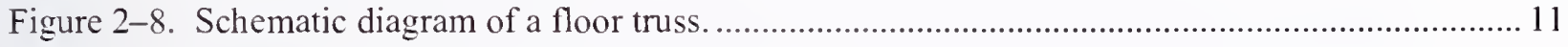

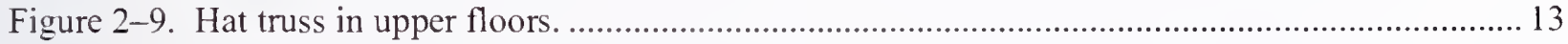


This page intentionally left blank. 


\section{LIST OF TABLES}

Table P-1. Federal building and fire safety investigation of the WTC disaster................................ xiv

Table P-2. Public meetings and briefings of the WTC Investigation.............................................xvii

Table 1-1. Metric equivalents of common yield strengths. ..................................................... 3

Table 2-1. Number of WTC 1 and 2 perimeter columns damaged by aircraft impact...................... 14

Table 2-2. Number of core columns with a given minimum yield strength within the floors

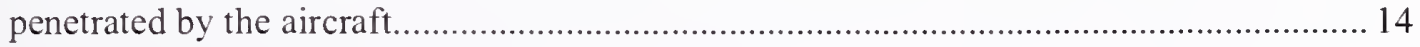

Table 2-3. Number of perimeter columns of specified grades in floors with significant fire. .............. 14

Table 2-4. Number of core columns of specified grades in floors with significant fire..................... 14

Table 3-1. Steels specified as acceptable by the Port Authority in its contract with steel fabricators.

Table 3-2. Summary of mechanical properties from relevant ASTM structural steel standards from WTC era

Table 3-3. Summary of chemistry data from relevant ASTM structural steel standards from

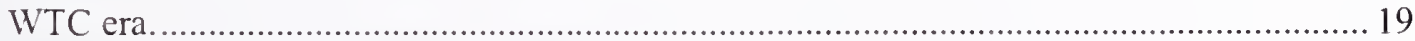

Table 3-4. Summary of Japan Industrial Standard structural steel standards from 1974 ...................20

Table 3-5. Steel companies involved in WTC construction and their contracts. ............................... 21

Table 3-6. Properties of Laclede ASTM A 242 steels obtained from Laclede mill reports................2 21

Table 3-7. Specified properties for Yawata contemporaneous steel grades...................................224

Table 3-8. Reported properties for Yawata contemporaneous steel grades. .................................... 25

Table 3-9. Mechanical properties of U.S. Steel and Bethlehem V-series steels. ..............................26

Table 3-10. Chemistry and mechanical property data for a Fuji Steel plate and a Colvilles plate used for core columns.

Table 3-11. Sources examined for mill reports and other construction information, other than the

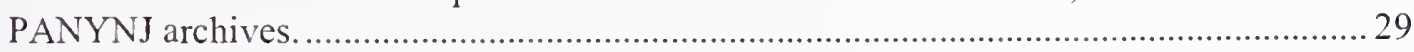

Table 3-12. Trade journals examined for WTC steel information. ................................................. 30

Table 3-13. Databases searched for WTC information................................................................ 30

Table 4-1. Comparison of chemistry requirements for ASTM A 325 "Standard Specification for High-Strength Bolts for Structural Steel Joints, including Suitable Nuts and Plain Hardened Washers" between 1970 and 2002 standards. 
This page intentionally left blank. 


\section{LIST OF ACRONYMS AND ABBREVIATIONS}

\section{Acronyms}

AISC American Institute of Steel Construction

AISI American Iron and Steel Institute

ASTM ASTM International

AWS American Welding Society

BPS Building Performance Study

FEMA Federal Emergency Management Agency

JIS Japan Industrial Standard

LERA Leslie E. Robertson Associates

NIST National Institute of Standards and Technology

PC\&F Pacific Car and Foundry

PANYNJ Port Authority of New York and New Jersey

PONYA Port of New York Authority

SEAoNY Structural Engineers Association of New York

SHCR Skilling, Helle, Christiansen, \& Robertson

SMA shielded metal arc

USC United States Code

WF wide flange (a type of structural steel shape now usually called a W-shape)

WTC World Trade Center

WTC 1 World Trade Center 1 (North Tower)

WTC 2 World Trade Center 2 (South Tower)

WTC 7 World Trade Center 7

\section{Abbreviations}

${ }^{\circ} \mathrm{C} \quad$ degrees Celsius

${ }^{\circ} \mathrm{F} \quad$ degrees Fahrenheit

$\mathrm{El}_{t} \quad$ total elongation

$\mathrm{ft} \quad$ foot

$F_{y} \quad$ yield strength (AISC usage) 


$\begin{array}{ll}\text { in. } & \text { inch } \\ \mathrm{L} & \text { liter } \\ \mathrm{lb} & \text { pound } \\ \mathrm{ksi} & 1,000 \mathrm{lb} / \mathrm{in}^{2} \\ \mathrm{~m} & \text { meter } \\ \mu \mathrm{m} & \text { micrometer } \\ \text { min } & \text { minute } \\ \mathrm{s} & \text { second } \\ \text { TS } & \text { tensile strength } \\ \text { YP } & \text { yield point (ASTM usage, see Table B-3) } \\ \text { YS } & \text { yield strength (ASTM usage, see Table B-3) }\end{array}$




\section{PREFACE}

\section{Genesis of This Investigation}

Immediately following the terrorist attack on the World Trade Center (WTC) on September 11, 2001, the Federal Emergency Management Agency (FEMA) and the American Society of Civil Engineers bcgan planning a building performance study of the disaster. The week of October 7 , as soon as the rescue and search efforts ceased. the Building Performance Study Team went to the site and began its assessment. This was to be a brief effort, as the study team consisted of experts who largely volunteered their time away from their other professional commitments. The Building Performance Study Team issued its report in May 2002. fulfilling its goal "to determine probable failure mechanisms and to identify areas of future investigation that could lead to practical measures for improving the damage resistance of buildings against such unforeseen events."

On August 21, 2002, with funding from the U.S. Congress through FEMA, the National Institute of Standards and Technology (NIST) announced its building and fire safety investigation of the WTC disaster. On October 1, 2002, the National Construction Safety Team Act (Public Law 107-231), was signed into law. The NIST WTC Investigation was conducted under the authority of the National Construction Safety Team Act.

The goals of the investigation of the WTC disaster were:

- To investigate the building construction, the materials used, and the technical conditions that contributed to the outcome of the WTC disaster.

- To serve as the basis for:

- Improvements in the way buildings are designed, constructed, maintained, and used;

- Improved tools and guidance for industry and safety officials;

- Recommended revisions to current codes, standards, and practices; and

- Improved public safety.

The specific objectives were:

1. Determine why and how WTC 1 and WTC 2 collapsed following the initial impacts of the aircraft and why and how WTC 7 collapsed;

2. Determine why the injuries and fatalities were so high or low depcnding on location, including all technical aspects of fire protection, occupant behavior, evacuation, and emergency response;

3. Determine what procedures and practices were used in the design, construction, operation, and maintenance of WTC 1, 2, and 7; and

4. Identify, as specifically as possible, areas in current building and fire codes, standards, and practices that warrant revision. 
NIST is a nonregulatory agency of the U.S. Department of Commerce's Technology Administration. The purpose of NIST investigations is to improve the safety and structural integrity of buildings in the United States, and the focus is on fact finding. NIST investigative teams are authorized to assess building performance and emergency response and evacuation procedures in the wake of any building failure that has resulted in substantial loss of life or that posed significant potential of substantial loss of life. NIST does not have the statutory authority to make findings of fault nor negligence by individuals or organizations. Further, no part of any report resuliting from a NIST investigation into a building failure or from an investigation under the National Construction Safety Team Act may be used in any suit or action for damages arising out of any matter mentioned in such report (15 USC 281a, as amended by Public Law 107-231).

\section{Organization of the Investigation}

The National Construction Safety Team for this Investigation, appointed by the then NIST Director, Dr. Arden L. Bement, Jr., was led by Dr. S. Shyam Sunder. Dr. William L. Grosshandler served as Associate Lead Investigator, Mr. Stephen A. Cauffman served as Program Manager for Administration, and Mr. Harold E. Nelson served on the team as a private sector expert. The Investigation included eight interdependent projects whose leaders comprised the remainder of the team. A detailed description of each of these eight projects is available at http://wtc.nist.gov. The purpose of each project is summarized in Table $\mathrm{P}-1$, and the key interdependencies among the projects are illustrated in Fig. $\mathrm{P}-1$.

\section{Table P-1. Federal building and fire safety investigation of the WTC disaster.}

\begin{tabular}{|c|c|}
\hline Technical Area and Project Leader & Project Purpose \\
\hline $\begin{array}{l}\text { Analysis of Building and Fire Codes and } \\
\text { Practices; Project Leaders: Dr. H. S. Lew } \\
\text { and Mr. Richard W. Bukowski }\end{array}$ & $\begin{array}{l}\text { Document and analyze the code provisions, procedures, and } \\
\text { practices used in the design, construction, operation, and } \\
\text { maintenance of the structural, passive fire protection, and } \\
\text { emergency access and evacuation systems of WTC } 1,2 \text {, and } 7 \text {. }\end{array}$ \\
\hline $\begin{array}{l}\text { Baseline Structural Performance and } \\
\text { Aircraft lmpact Damage Analysis; Project } \\
\text { Leader: Dr. Fahim H. Sadek }\end{array}$ & $\begin{array}{l}\text { Analyze the baseline performance of WTC } 1 \text { and WTC } 2 \text { under } \\
\text { design, service, and abnormal loads, and aircraft impact damage on } \\
\text { the structural, fire protection, and egress systems. }\end{array}$ \\
\hline $\begin{array}{l}\text { Mechanical and Metallurgical Analysis of } \\
\text { Structural Steel; Project Leader: Dr. Frank } \\
\text { W. Gayle }\end{array}$ & $\begin{array}{l}\text { Determine and analyze the mechanical and metallurgical properties } \\
\text { and quality of steel, weldments, and connections from steel } \\
\text { recovered from WTC } 1,2 \text {, and } 7 \text {. }\end{array}$ \\
\hline $\begin{array}{l}\text { Investigation of Active Fire Protection } \\
\text { Systems; Project Leader: Dr. David } \\
\text { D. Evans; Dr. William Grosshandler }\end{array}$ & $\begin{array}{l}\text { Investigate the performance of the active fire protection systems in } \\
\text { WTC } 1,2 \text {, and } 7 \text { and their role in fire control, emergency response, } \\
\text { and fate of occupants and responders. }\end{array}$ \\
\hline $\begin{array}{l}\text { Reconstruction of Thermal and Tenability } \\
\text { Environment; Project Leader: Dr. Richard } \\
\text { G. Gann }\end{array}$ & $\begin{array}{l}\text { Reconstruct the time-evolving temperature, thermal environment, } \\
\text { and smoke movement in WTC } 1,2 \text {, and } 7 \text { for use in evaluating the } \\
\text { structural performance of the buildings and behavior and fate of } \\
\text { occupants and responders. }\end{array}$ \\
\hline $\begin{array}{l}\text { Structural Fire Response and Collapse } \\
\text { Analysis; Project Leaders: Dr. John } \\
\text { L. Gross and Dr. Therese P. McAllister }\end{array}$ & $\begin{array}{l}\text { Analyze the response of the WTC towers to fires with and without } \\
\text { aircraft damage, the response of WTC } 7 \text { in fires, the performance } \\
\text { of composite steel-trussed floor systems, and determine the most } \\
\text { probable structural collapse sequence for WTC } 1,2 \text {, and } 7 \text {. }\end{array}$ \\
\hline $\begin{array}{l}\text { Occupant Behavior, Egress, and Emergency } \\
\text { Communications; Project Leader: Mr. Jason } \\
\text { D. Averill }\end{array}$ & $\begin{array}{l}\text { Analyze the behavior and fate of occupants and responders, both } \\
\text { those who survived and those who did not. and the performance of } \\
\text { the evacuation system. }\end{array}$ \\
\hline $\begin{array}{l}\text { Emergency Response Technologies and } \\
\text { Guidelines; Project Leader: Mr. J. Randall } \\
\text { Lawson }\end{array}$ & $\begin{array}{l}\text { Document the activities of the emergency responders from the time } \\
\text { of the terrorist attacks on WTC } 1 \text { and WTC } 2 \text { until the collapse of } \\
\text { WTC } 7 \text {, including practices followed and technologies used. }\end{array}$ \\
\hline
\end{tabular}




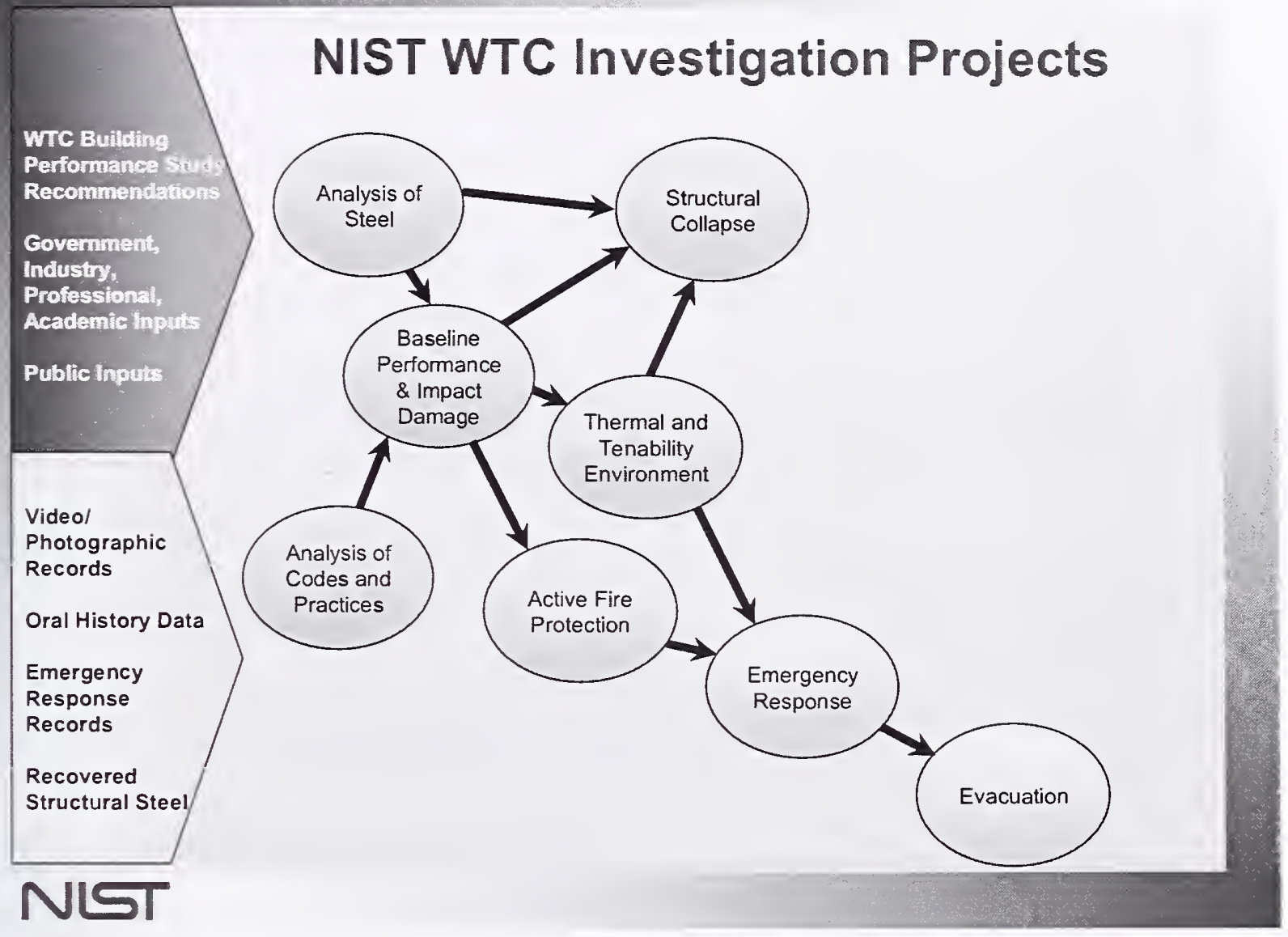

Figure $P-1$. The eight projects in the federal building and fire safety investigation of the WTC disaster.

\section{National Construction Safety Team Advisory Committee}

The NIST Director also established an advisory committee as mandated under the National Construction Safety Team Act. The initial members of the committee were appointed following a public solicitation. These were:

- Paul Fitzgerald, Executive Vice President (retired) FM Global, National Construction Safety Team Advisory Committee Chair

- John Barsom, President, Barsom Consulting, Ltd.

- John Bryan, Professor Emeritus, University of Maryland

- David Collins, President, The Preview Group, Inc.

- Glenn Corbett, Professor, John Jay College of Criminal Justice

- Philip DiNenno, President, Hughes Associates, Inc. 
- Robert Hanson, Professor Emeritus, University of Michigan

- Charles Thornton, Co-Chairman and Managing Principal, The Thornton-Tomasetti Group, Inc.

- Kathleen Tierney, Director, Natural Hazards Research and Applications Information Center, University of Colorado at Boulder

- Forman Williams, Director, Center for Energy Research, University of California at San Diego

This National Construction Safety Team Advisory Committee provided technical advice during the Investigation and commentary on drafts of the Investigation reports prior to their public release. NIST has benefited from the work of many people in the preparation of these reports, including the National Construction Safety Team Advisory Committce. The content of the reports and recommendations, however, are solely the responsibility of NIST.

\section{Public Outreach}

During the course of this Investigation, NIST hcld public briefings and meetings (listed in Table P-2) to solicit input from the public, present preliminary findings, and obtain comments on the direction and progress of the Investigation from the public and the Advisory Committee.

NIST maintained a publicly accessible Web site during this Investigation at http://wtc.nist.gov. The site contained extensive information on the background and progress of the Investigation.

\section{NIST's WTC Public-Private Response Plan}

The collapse of the WTC buildings has led to broad reexamination of how tall buildings are designed, constructed, maintained, and used, especially with regard to major events such as fires, natural disasters, and terrorist attacks. Reflecting the enhanced interest in effecting necessary change, NIST, with support from Congress and the Administration, has put in place a program, the goal of which is to develop and implement the standards, technology, and practices needed for cost-effective improvements to the safety and security of buildings and building occupants, including evacuation, emergency response procedures, and threat mitigation.

The strategy to meet this goal is a three-part NIST-led public-private response program that includes:

- A fedcral building and fire safety investigation to study the most probable factors that contributed to post-aircraft impact collapse of the WTC towers and the 47-story WTC 7 building, and the associated evacuation and emergency response experience.

- A research and development (R\&D) program to (a) facilitate the implementation of recommendations resulting from the WTC Investigation, and (b) provide the technical basis for cost-effective improvements to national building and fire codes, standards, and practices that enhance the safety of buildings, their occupants, and emergency responders. 
Table P-2. Public meetings and briefings of the WTC Investigation.

\begin{tabular}{|c|c|c|}
\hline Date & Location & Principal Agenda \\
\hline June 24,2002 & New York City, NY & $\begin{array}{l}\text { Public meeting: Public comments on the Draft Plan for the } \\
\text { pending WTC Investigation. }\end{array}$ \\
\hline August 21,2002 & Gaithersburg, MD & Media briefing announcing the formal start of the Investigation. \\
\hline December 9, 2002 & Washington, DC & $\begin{array}{l}\text { Media briefing on release of the Public Update and NIST request } \\
\text { for photographs and videos. }\end{array}$ \\
\hline April 8, 2003 & New York City, NY & $\begin{array}{l}\text { Joint public forum with Columbia University on first-person } \\
\text { interviews. }\end{array}$ \\
\hline April 29-30, 2003 & Gaithersburg, MD & $\begin{array}{l}\text { NCST Advisory Committee meeting on plan for and progress on } \\
\text { WTC Investigation with a public comment session. }\end{array}$ \\
\hline May 7,2003 & New York City, NY & Media briefing on release of May 2003 Progress Report. \\
\hline August 26-27, 2003 & Gaithersburg, MD & $\begin{array}{l}\text { NCST Advisory Committee meeting on status of the WTC } \\
\text { investigation with a public comment session. }\end{array}$ \\
\hline September 17,2003 & New York City, NY & $\begin{array}{l}\text { Media and public briefing on initiation of first-person data } \\
\text { collection projects. }\end{array}$ \\
\hline December 2-3, 2003 & Gaithersburg, MD & $\begin{array}{l}\text { NCST Advisory Committee meeting on status and initial results } \\
\text { and release of the Public Update with a public comment session. }\end{array}$ \\
\hline February 12,2004 & New York City, NY & $\begin{array}{l}\text { Public meeting on progress and preliminary findings with public } \\
\text { comments on issues to be considered in formulating final } \\
\text { recommendations. }\end{array}$ \\
\hline June 18,2004 & New York City, NY & Media/public briefing on release of June 2004 Progress Report. \\
\hline June $22-23,2004$ & Gaithersburg, MD & $\begin{array}{l}\text { NCST Advisory Committee meeting on the status of and } \\
\text { preliminary findings from the WTC Investigation with a public } \\
\text { comment session. }\end{array}$ \\
\hline August 24,2004 & Northbrook, IL & $\begin{array}{l}\text { Public viewing of standard fire resistance test of WTC floor } \\
\text { system at Underwriters Laboratories, Inc. }\end{array}$ \\
\hline October $19-20,2004$ & Gaithersburg, MD & $\begin{array}{l}\text { NCST Advisory Committee meeting on status and near complete } \\
\text { set of preliminary findings with a public comment session. }\end{array}$ \\
\hline November 22,2004 & Gaithersburg, MD & $\begin{array}{l}\text { NCST Advisory Committee discussion on draft annual report to } \\
\text { Congress, a public comment session, and a closed session to } \\
\text { discuss pre-draft recommendations for WTC Investigation. }\end{array}$ \\
\hline April 5, 2005 & New York City, NY & $\begin{array}{l}\text { Media and public briefing on release of the probable collapse } \\
\text { sequence for the WTC towers and draft reports for the projects on } \\
\text { codes and practices, evacuation, and emergency response. }\end{array}$ \\
\hline June 23,2005 & New York City, NY & $\begin{array}{l}\text { Media and public briefing on release of all draft reports for the } \\
\text { WTC towers and draft recommendations for public comment. }\end{array}$ \\
\hline $\begin{array}{l}\text { September 12-13, } \\
2005\end{array}$ & Gaithersburg, MD & $\begin{array}{l}\text { NCST Advisory Committee meeting on disposition of public } \\
\text { comments and update to draft reports for the WTC towers. }\end{array}$ \\
\hline $\begin{array}{l}\text { September 13-15, } \\
2005\end{array}$ & Gaithersburg, MD & $\begin{array}{l}\text { WTC Technical Conference for stakeholders and technical } \\
\text { community for dissemination of findings and recommendations } \\
\text { and opportunity for public to make technical comments. }\end{array}$ \\
\hline
\end{tabular}

- A dissemination and technical assistance program (DTAP) to (a) engage leaders of the construction and building community in ensuring timely adoption and widespread use of proposed changes to practices, standards, and codes resulting from the WTC Investigation and the R\&D program, and (b) provide practical guidance and tools to better prepare facility owners, contractors, architects, engineers, emergency responders, and regulatory authorities to respond to future disasters.

The desired outcomes are to make buildings, occupants, and first responders safer in future disaster events. 


\section{National Construction Safety Team Reports on the WTC Investigation}

A final report on the collapse of the WTC towers is being issued as NIST NCSTAR 1. A companion report on the collapse of WTC 7 is being issued as NIST NCSTAR 1A. The present report is one of a set that provides more detailed documentation of the Investigation findings and the means by which these technical results were achieved. As such, it is part of the archival record of this Investigation. The titles of the full set of Investigation publications are:

NIST (National Institute of Standards and Technology). 2005. Federal Building and Fire Safety Investigation of the World Trade Center Disaster: Final Report on the Collapse of the World Trade Center Towers. NIST NCSTAR 1. Gaithersburg, MD, September.

NIST (National Institute of Standards and Technology). 2006. Federal Building and Fire Safety Investigation of the World Trade Center Disaster: Final Report on the Collapse of World Trade Center 7. NIST NCSTAR 1A. Gaithersburg, MD.

Lew, H. S., R. W. Bukowski, and N. J. Carino. 2005. Federal Building and Fire Safety Investigation of the World Trade Center Disaster: Design, Construction, and Maintenance of Structural and Life Safety Systems. NIST NCSTAR 1-1. National Institute of Standards and Technology. Gaithersburg, MD, September.

Fanella, D. A., A. T. Derecho, and S. K. Ghosh. 2005. Federal Building and Fire Safety Investigation of the World Trade Center Disaster: Design and Construction of Strlictural Systems. NIST NCSTAR 1-1A. National Institute of Standards and Technology. Gaithersburg, MD, September.

Ghosh, S. K., and X. Liang. 2005. Federal Building and Fire Safety Investigation of the World Trade Center Disaster: Comparison of Building Code Structural Requirements. NIST NCSTAR 1-1B. National Institute of Standards and Technology. Gaithersburg, MD, September.

Fanella, D. A., A. T. Derecho, and S. K. Ghosh. 2005. Federal Building and Fire Safety Investigation of the World Trade Center Disaster: Maintenance and Modifications to Structural Systems. NIST NCSTAR 1-1C. National Institute of Standards and Technology. Gaithersburg, MD, September.

Grill, R. A., and D. A. Johnson. 2005. Federal Building and Fire Safety Investigation of the World Trade Center Disaster: Fire Protection and Life Safety Provisions Applied to the Design and Construction of World Trade Center 1, 2, and 7 and Post-Construction Provisions Applied after Occupancy. NIST NCSTAR 1-1D. National Institute of Standards and Technology. Gaithersburg, MD, September.

Razza, J. C., and R. A. Grill. 2005. Federal Building and Fire Safety Investigation of the World Trade Center Disaster: Contparison of Codes, Standards, and Practices in Use at the Time of the Design and Construction of World Trade Center 1, 2, and 7. NIST NCSTAR 1-1E. National Institute of Standards and Technology. Gaithersburg, MD, September.

Grill, R. A., D. A. Johnson, and D. A. Fanella. 2005. Federal Building and Fire Safety Investigation of the World Trade Center Disaster: Conparison of the 1968 and Current (2003) New 
York City Building Code Provisions. NIST NCSTAR 1-1F. National Institute of Standards and Technology. Gaithersburg, MD, September.

Grill, R. A., and D. A. Johnson. 2005. Federal Building and Fire Safety Investigation of the World Trade Center Disaster: Amendments to the Fire Protection and Life Safety Provisions of the New York City Building Code by Local Law's Adopted While World Trade Center 1, 2, and 7 Were in Use. NIST NCSTAR 1-1G. National Institute of Standards and Technology. Gaithersburg, MD, September.

Grill, R. A., and D. A. Johnson. 2005. Federal Building and Fire Safety Investigation of the World Trade Center Disaster: Post-Construction Modifications to Fire Protection and Life Safety Systems of World Trade Center 1 and 2. NIST NCSTAR 1-1H. National Institute of Standards and Technology. Gaithersburg, MD, September.

Grill, R. A., D. A. Johnson, and D. A. Fanella. 2005. Federal Building and Fire Safety Investigation of the World Trade Center Disaster: Post-Construction Modifications to Fire Protection, Life Safety, and Structural Systems of World Trade Center 7. NIST NCSTAR 1-1I. National Institute of Standards and Technology. Gaithersburg, MD, September.

Grill, R. A., and D. A. Johnson. 2005. Federal Building and Fire Safety Investigation of the World Trade Center Disaster: Design, Installation, and Operation of Fuel System for Emergency Power in World Trade Center 7. NIST NCSTAR 1-1J. National Institute of Standards and Technology. Gaithersburg, MD, September.

Sadek, F. 2005. Federal Building and Fire Safety Investigation of the World Trade Center Disaster: Baseline Structural Performance and Aircraft Impact Damage Analysis of the World Trade Center Towers. NIST NCSTAR 1-2. National Institute of Standards and Technology. Gaithersburg, MD, September.

Faschan, W. J., and R. B. Garlock. 2005. Federal Building and Fire Safety Investigation of the World Trade Center Disaster: Reference Structural Models and Baseline Performance Analysis of the World Trade Center Towers. NIST NCSTAR 1-2A. National Institute of Standards and Technology. Gaithersburg, MD, September.

Kirkpatrick, S. W., R. T. Bocchieri, F. Sadek, R. A. MacNeill, S. Holmes, B. D. Peterson, R. W. Cilke, C. Navarro. 2005. Federal Building and Fire Safety Investigation of the World Trade Center Disaster: Analysis of Aircraft Impacts into the World Trade Center Towers, NIST NCSTAR 1-2B. National Institute of Standards and Technology. Gaithersburg, MD, September.

Gayle, F. W., R. J. Fields, W. E. Luecke, S. W. Banovic, T. Foecke, C. N. McCowan, T. A. Siewert, and J. D. McColskey. 2005. Federal Building and Fire Safety Investigation of the World Trade Center Disaster: Mechanical and Metallurgical Analysis of Structural Steel. NIST NCSTAR 1-3. National Institute of Standards and Technology. Gaithersburg, MD, September.

Luecke, W. E., T. A. Siewert, and F. W. Gayle. 2005. Federal Building and Fire Safety Investigation of the World Trade Center Disaster: Contemporaneous Structural Steel Specifications. NIST Special Publication 1-3A. National Institute of Standards and Technology. Gaithersburg, MD, September. 
Banovic, S. W. 2005. Federal Building and Fire Safety Investigation of the World Trade Center Disaster: Steel Inventory and Identification. NIST NCSTAR 1-3B. National Institute of Standards and Technology. Gaithersburg, MD, September.

Banovic, S. W., and T. Foecke. 2005. Federal Building and Fire Safety Investigation of the World Trade Center Disaster: Damage and Failure Modes of Structural Steel Components. NIST NCSTAR 1-3C. National Institute of Standards and Technology. Gaithersburg, MD, September.

Luecke, W. E., J. D. McColskey, C. N. McCowan, S. W. Banovic, R. J. Fields, T. Foecke, T. A. Siewert, and F. W. Gayle. 2005. Federal Building and Fire Safety Investigation of the World Trade Center Disaster: Mechanical Properties of Structural Steels. NIST NCSTAR 1-3D. National Institute of Standards and Technology. Gaithersburg, MD, September.

Banovic, S. W., C. N. McCowan, and W. E. Luecke. 2005. Federal Building and Fire Safety Investigation of the World Trade Center Disaster: Physical Properties of Structural Steels. NIST NCSTAR 1-3E. National Institute of Standards and Technology. Gaithersburg, MD, September.

Evans, D. D., R. D. Peacock, E. D. Kuligowski, W. S. Dols, and W. L. Grosshandler. 2005. Federal Building and Fire Safety Investigation of the World Trade Center Disaster: Active Fire Protection Systems. NIST NCSTAR 1-4. National Institute of Standards and Technology. Gaithersburg, MD, September.

Kuligowski, E. D., D. D. Evans, and R. D. Peacock. 2005. Federal Building and Fire Safety Investigation of the World Trade Center Disaster: Post-Construction Fires Prior to September 11, 2001. NIST NCSTAR 1-4A. National Institute of Standards and Technology. Gaithersburg, MD, September.

Hopkins, M., J. Schoenrock, and E. Budnick. 2005. Federal Building and Fire Safety Investigation of the World Trade Center Disaster: Fire Suppression Systems. NIST NCSTAR 1-4B. National Institute of Standards and Technology. Gaithersburg, MD, September.

Keough, R. J., and R. A. Grill. 2005. Federal Building and Fire Safety Investigation of the World Trade Center Disaster: Fire Alarm Systems. NIST NCSTAR 1-4C. National Institute of Standards and Technology. Gaithersburg, MD, September.

Ferreira, M. J., and S. M. Strege. 2005. Federal Building and Fire Safety Investigation of the World Trade Center Disaster: Snoke Management Systems. NIST NCSTAR 1-4D. National Institute of Standards and Technology. Gaithersburg, MD, September.

Gann, R. G., A. Hamins, K. B. McGrattan, G. W. Mulholland, H. E. Nelson, T. J. Ohlemiller, W. M. Pitts, and K. R. Prasad. 2005. Federal Building and Fire Safety Investigation of the World Trade Center Disaster: Reconstruction of the Fires in the World Trade Center Towers. NIST NCSTAR 1-5. National Institute of Standards and Technology. Gaithersburg, MD, September.

Pitts, W. M., K. M. Butler, and V. Junker. 2005. Federal Building and Fire Safety Investigation of the World Trade Center Disaster: Visual Evidence, Damage Estimates, and Timeline Analysis. NIST NCSTAR 1-5A. National Institute of Standards and Technology. Gaithersburg, MD, September. 
Hamins, A., A. Maranghides, K. B. McGrattan, E. Johnsson, T. J. Ohlemiller, M. Donnelly, J. Yang, G. Mulholland, K. R. Prasad, S. Kukuck, R. Anleitner and T. McAllister. 2005. Federal Building and Fire Safety Investigation of the World Trade Center Disaster: Experiments and Modeling of Structwral Steel Elements Exposed to Fire. NIST NCSTAR 1-5B. National Institute of Standards and Technology. Gaithersburg, MD, September.

Ohlemiller, T. J., G. W. Mulholland, A. Maranghides, J. J. Filliben, and R. G. Gann. 2005. Federal Building and Fire Safety Investigation of the World Trade Center Disaster: Fire Tests of Single Office Workstations. NIST NCSTAR 1-5C. National Institute of Standards and Technology. Gaithersburg, MD, September.

Gann, R. G., M. A. Riley, J. M. Repp, A. S. Whittaker, A. M. Reinhorn, and P. A. Hough. 2005. Federal Building and Fire Safety Investigation of the World Trade Center Disaster: Reaction of Ceiling Tile Systems to Shocks. NIST NCSTAR 1-5D. National Institute of Standards and Technology. Gaithersburg, MD, September.

Hamins, A., A. Maranghides, K. B. McGrattan, T. J. Ohlemiller, and R. Anleitner. 2005. Federal Building and Fire Safety Investigation of the World Trade Center Disaster: Experinents and Modeling of Multiple Workstations Burning in a Conipartment. NIST NCSTAR 1-5E. National Institute of Standards and Technology. Gaithersburg, MD, September.

McGrattan, K. B., C. Bouldin, and G. Forney. 2005. Federal Burilding and Fire Safety Investigation of the World Trade Center Disaster: Computer Simulation of the Fires in the World Trade Center Towers. NIST NCSTAR 1-5F. National Institute of Standards and Technology. Gaithersburg, MD, September.

Prasad, K. R., and H. R. Baum. 2005. Federal Building and Fire Safety Investigation of the World Trade Center Disaster: Fire Strmctme Interface and Thermal Response of the World Trade Center Towers. NIST NCSTAR 1-5G. National Institute of Standards and Technology. Gaithersburg, MD, September.

Gross, J. L., and T. McAllister. 2005. Federal Building and Fire Safety Investigation of the World Trade Center Disaster: Strlctural Fire Response and Probable Collapse Sequence of the World Trade Center Towers. NIST NCSTAR 1-6. National Institute of Standards and Technology. Gaithersburg, MD, September.

Carino, N. J., M. A. Starnes, J. L. Gross, J. C. Yang, S. Kukuck, K. R. Prasad, and R. W. Bukowski. 2005. Federal Btrilding and Fire Safety Investigation of the World Trade Center Disaster: Passive Fire Protection. NIST NCSTAR 1-6A. National Institute of Standards and Technology. Gaithersburg, MD, September.

Gross, J., F. Hervey, M. Izydorek, J. Mammoser, and J. Treadway. 2005. Federal Building and Fire Safety Investigation of the World Trade Center Disaster: Fire Resistance Tests of Floor Truss Systems. NIST NCSTAR 1-6B. National Institute of Standards and Technology. Gaithersburg, MD, September.

Zarghamee, M. S., S. Bolourchi, D. W. Eggers, Ö. O. Erbay, F. W. Kan, Y. Kitane, A. A. Liepins, M. Mudlock, W. I. Naguib, R. P. Ojdrovic, A. T. Sarawit, P. R Barrett, J. L. Gross, and 
T. P. McAllister. 2005. Federal Building and Fire Safety Investigation of the World Trade Center Disaster: Component, Connection, and Subsystem Structural Analysis. NIST NCSTAR 1-6C. National Institute of Standards and Technology. Gaithersburg, MD, September.

Zarghamee, M. S., Y. Kitane, Ö. O. Erbay, T. P. McAllister, and J. L. Gross. 2005. Federal Building and Fire Safety Investigation of the World Trade Center Disaster: Global Structural Analysis of the Response of the World Trade Center Towers to Impact Damage and Fire. NIST NCSTAR 1-6D. National Institute of Standards and Technology. Gaithersburg, MD, September.

McAllister, T., R. W. Bukowski, R. G. Gann, J. L. Gross, K. B. McGrattan, H. E. Nelson, L. Phan, W. M. Pitts, K. R. Prasad, F. Sadek. 2006. Federal Building and Fire Safety Investigation of the World Trade Center Disaster: Strnctural Fire Response and Probable Collapse Sequence of World Trade Center 7. (Provisional). NIST NCSTAR 1-6E. National Institute of Standards and Technology. Gaithersburg, MD.

Gilsanz, R., V. Arbitrio, C. Anders, D. Chlebus, K. Ezzeldin, W. Guo, P. Moloney, A. Montalva, J. Oh, K. Rubenacker. 2006. Federal Building and Fire Safety Investigation of the World Trade Center Disaster: Strnctural Analysis of the Response of World Trade Center 7 to Debris Damage and Fire. (Provisional). NIST NCSTAR 1-6F. National Institute of Standards and Technology. Gaithersburg, MD.

Kim, W. 2006. Federal Building and Fire Safety Investigation of the World Trade Center Disaster: Analysis of September 11, 2001, Seismogram Data. (Provisional). NIST NCSTAR 1-6G. National Institute of Standards and Technology. Gaithersburg, MD.

Nelson, K. 2006. Federal Building and Fire Safety Investigation of the World Trade Center Disaster: The Con Ed Substation in World Trade Center 7. (Provisional). NIST NCSTAR 1-6H. National Institute of Standards and Technology. Gaithersburg, MD.

Averill, J. D., D. S. Mileti, R. D. Peacock, E. D. Kuligowski, N. Groner, G. Proulx, P. A. Reneke, and H. E. Nelson. 2005. Federal Building and Fire Safety Investigation of the World Trade Center Disaster: Occmpant Behavior, Egress, and Emergency Communication. NIST NCSTAR 1-7. National Institute of Standards and Technology. Gaithersburg, MD, September.

Fahy, R., and G. Proulx. 2005. Federal Building and Fire Safety Investigation of the World Trade Center Disaster: Analysis of Published Accoumts of the World Trade Center Evacuation. NIST NCSTAR 1-7A. National Institute of Standards and Technology. Gaithersburg, MD, September.

Zmud, J. 2005. Federal Building and Fire Safety Investigation of the World Trade Center Disaster: Technical Documentation for Smvey Administration. NIST NCSTAR 1-7B. National Institute of Standards and Technology. Gaithersburg, MD, September.

Lawson, J. R., and R. L. Vettori. 2005. Federal Bnilding and Fire Safety Investigation of the World Trade Center Disaster: The Emergency Response Operations. NIST NCSTAR 1-8. National Institute of Standards and Technology. Gaithersburg, MD, September. 


\section{EXECUTIVE SUMMARY}

This report reviews the contemporaneous (1960s era) steel and welding specifications used to construct the 110-story World Trade Center (WTC) towers. The many grades of steel that were used are characterized based on structural engineering specifications for the buildings and the manufacturers' documents of the era. The major structural elements in the towers relevant to this investigation led by the National Institute of Standards and Technology are also described.

Structurally, the buildings were a frame-tube construction with a conventional column and beam core. The perimeter "frame-tube" consisted of closely spaced high-strength perimeter columns. Floor trusses were used to span between the perimeter columns and the core.

Ten different steel companies fabricated structural elements for the two towers. The floors involved in the aircraft impact and major fires on September 11, 2001, contained steel from four of these companies.

- Laclede Steel (St. Louis, Missouri) fabricated the trusses for the floor panels that spanned the opening between the core and the perimeter columns. They used steels conforming to ASTM International (ASTM) A 36 and A 242, which they made and rolled in their own mill. Contemporaneous mill reports indicate that many of the floor truss components specified as ASTM A 36 were fabricated with a micro-alloyed steel of considerably higher yield strength.

- Pacific Car and Foundry (Seattle, Washington) fabricated the perimeter box column panels (generally three columns wide by three stories tall) above the 9th floor. Although 14 grades of steel (36 to $100 \mathrm{ksi}$ yield strength) were specified in the structural steel drawings. only 12 grades were supplied due to an upgrading of two of the specified steels. Most of the 12 grades of steel came from Yawata Iron and Steel (now Nippon Steel) and Kawasaki Steel, although about 10 percent of the plate was produced domestically, primarily by Bethlehem Steel. All these steels were relatively new, proprietary steels, with specifications that differed from ASTM standards of the time. In the impact zones of the towers, the perimeter columns damaged by the aircraft were primarily of three specified grades: $(55,60$, and 65) ksi steels.

- Stanray Pacific (Los Angeles, California) fabricated the welded core box columns (rectangular columns assembled from four steel plates) above the 7th floor, primarily using steels conforming to ASTM A 36. The thicker plates came from Colvilles, Ltd. (Motherwell, Scotland, now Corus Steel), while the thinner plates came from Fuji Steel (now Nippon Steel).

- Montague-Betts (Lynchburg, Virginia) fabricated all of the rolled wide flange core columns and beams above the 9 th floor. About 40 percent of the steel (by weight) for the wide flange columns came from Yawata Iron and Steel. They obtained the rest from numerous domestic suppliers. For WTC 1, the core columns damaged by impact and fire were mostly wide flange shapes, because of the high elevation of the impact. In WTC 2, the columns damaged were a roughly equal mix of welded box columns and wide flange shapes. 
The contract between the Port of New York Authority (PONYA or Port Authority) and the fabricators required that the steels supplied meet either certain ASTM standards or specific proprietary steels. Other proprietary steels were allowed provided that the Port Authority engineer-in-charge approved them. A limited number of mill reports from the construction era were found for the steels in the floor trusses and perimeter panels. These reports indicated that the steel met or exceeded the required strengths.

The major findings of this report are:

- 14 grades (i.e., strengths) of steel were specified in the structural engineering plans, but only 12 grades of steel were actually used in construction due to an upgrade of two grades.

- Ten different steel companies fabricated structural elements for the towers, using steel supplied from at least eight different suppliers. Four fabricators supplied the major structural elements of the 9 th to 107 th floors.

- Although ASTM structural steel standards have evolved since the construction of the towers, the changes have been minor and do not represent changes to the basic mechanical properties of the steels. 


\section{Chapter 1 \\ INTRODUCTION}

One of the purposes of the National Institute of Standards and Technology (NIST) World Trade Center (WTC) Investigation is to analyze structural steel available from WTC 1, 2, and 7 for determining the metallurgical and mechanical properties and quality of the metal, weldments, and connections. The properties determined under this analysis will be used in two ways:

1. Properties will be correlated with the design requirements of the buildings to determine whether the specified steel was in place in the towers.

2. Properties will be supplied for other projects in the Investigation as input for models of building performance.

\section{$1.1 \quad$ SCOPE OF REPORT}

This report covers the tower design (structural steel documents) and contemporaneous structural steel and construction specifications. A separate report (NIST NCSTAR 1-3B, Steel Inventory and Identification) ${ }^{1}$ catalogs the steel currently held by NIST for the Investigation purposes.

Chapter 2 of this report describes the tower structure and critical structural elements to be characterized. This includes the structural design and properties specified by the structural engineers for columns, floor systems, and connections.

Chapter 3 describes the contemporaneous (late 1960s era) specifications for various types and grades of steel designated by ASTM International (ASTM), the American Institute of Steel Construction (AISC), and other national and international organizations. It also includes information from numerous suppliers of the steel for the structure. The structural steel for the towers was supplied through at least a dozen contracts to suppliers and fabricators. Substantial understanding of the consistency, quality, and actual strength of the steel (as opposed to specified minimum values) can be gained if the production practices and quality control procedures used by the various steel suppliers are understood. Practices and data from the numerous WTC steel suppliers have been investigated and are reported for both structural steel and construction practices. In addition, this information has been used to estimate typical mechanical property values for the many of the grades of steel. These typical values can serve as a guide for the properties to be inserted into the finite element models of building performance and as a point of comparison for actual properties measured on the recovered steel.

Chapter 4 reviews the standards and specifications used in welding the built-up columns, and those used in the erection of the towers.

1 This reference is to one of the companion documents from this Investigation. A list of these documents appears in the Preface to this report. 
NIST NCSTAR 1-3B documents the steel rccovered for the WTC Investigation. Approximately 236 pieces of WTC steel were selected for study at NIST. These pieces represent a small fraction of the steel examined at the various salvage yards where the steel was scnt as the WTC site was cleared.

\subsection{SPECIFICATION OF STEEL GRADES (MINIMUM YIELD STRENGTH)}

Specifications (ASTM, AISI, etc.) typically place limits on chemical composition or mechanical properties or, most commonly, both. Various mechanical properties may be specified, such as tensile strength, minimum yield strength, ductility, and toughness. Other material properties may not appear in a specification, yet are critical in building design; the most important such property is perhaps the elastic modulus, or stiffness, which does not appear in specifications because there is little variability amongst the various steels.

In practice, the material property of greatest importance for characterizing a particular steel is the yield strength $\left(F_{y}\right)$. In the U.S., steel is often referred to according to its yield strength; for example, a "50 ksi steel" is steel with a minimum yield strength of $50,000 \mathrm{lb} /$ in. $^{2}$. Skilling, Helle, Christiansen, \& Robertson (SHCR), structural engineers for the WTC towers, followed this convention, and the design drawings are marked with the minimum yield strength for each piece of structural steel.

\section{$1.3 \quad$ UNITS AND ABBREVIATIONS}

This report expresses the yield strengths of the steels and the dimensions of the building in English units with metric (SI) equivalents. The steels were specified to English unit-based ASTM standards, and the building was built to foot and inch dimensions. ASTM standards differentiate between English and metric units by denoting them with completely different designations and frequently by publishing them as separate documents. This document will use English units for values that were contractually specified during the construction (primarily component dimensions and steel strengths). Table 1-1 shows the SI equivalents of the common yield strength grades of steel.

In reviewing some of the historical documents, NIST found ambiguities in the use of the measure "ton." NIST has assumed that in any source originating in the United States, a "ton" refers to 2,000 lb (i.e., a short ton). For sources originating in Japan, NIST assumes that a "ton" refers to $1,000 \mathrm{~kg}(=2,204.6 \mathrm{lb}$, i.e., a metric ton). For any source originating in Great Britain, NIST assumes that a "ton" is 2,240 lb (a "long" or UK ton) and that a "tonne" is $1,000 \mathrm{~kg}$. In this report, all weights in tons are converted to short tons $(=2,000 \mathrm{lb})$.

The common acronyms and symbols that appear in this report are shown in the List of Acronyms and Abbreviations. This report follows the AISI convention and denotes yield strength with the symbol $F_{y}$. The ASTM uses the symbols YS (or YP) and $S_{y}$.

\section{$1.4 \quad$ SOURCES OF INFORMATION}

This report is based on three different types of sources. Open literature sources like journal and trade magazine articles, books, historical standards, and publicly searchable databases comprise the first type. The second type comprises personal interviews by NIST investigators with individuals and company representatives, and information they provided voluntarily. Sources of information where NIST has 
entered into Material Transfer Agreements with organizations or individuals comprise the third type. Documents provided by the Port Authority of New York and New Jersey (PANYNJ), which is the source of most of the contemporaneous information on the construction of the buildings, is an example of the third type. This archive has been useful in identifying the specific steels and standards used in the construction. Although it is voluminous, the PANYNJ archive does not include every document generated during the construction of the towers. Section 3.4 summarizes the search strategies for open literature information and provides details on the companies and individuals contacted and the information they provided

This report identifies the type of source in the reference. For example, a reference to a book or other publicly available document appears as (Smith 1968). The symbol $\dagger$ denotes a personal communication to a NIST investigator, for example (Jones $2003 \dagger$ ). In the case of a source bound by a Material Transfer Agreement, the symbol $\S$ appears in the reference, for example (Monti $1969 \S$ ). The reference lists appear as Secs. 5.1 to 5.3 .

Table 1-1. Metric equivalents of common yield strengths.

\begin{tabular}{|c|c|}
\hline ksi & MPa \\
\hline 36 & 248 \\
\hline 42 & 290 \\
\hline 45 & 310 \\
\hline 46 & 317 \\
\hline 50 & 345 \\
\hline 55 & 379 \\
\hline 60 & 414 \\
\hline 65 & 448 \\
\hline 70 & 483 \\
\hline 75 & 517 \\
\hline 80 & 552 \\
\hline 85 & 586 \\
\hline 90 & 621 \\
\hline 100 & 689 \\
\hline & \\
\hline
\end{tabular}


This page intentionally left blank. 


\section{Chapter 2 \\ TOWER DESIGN - STRUCTURAL STEEL DOCUMENTS}

\section{$2.1 \quad$ STRUCTURAL OVERVIEW}

The World Trade Center (WTC) tower buildings had a frame-tube construction consisting of closely spaced perimeter columns coupled to a rectangular service core (Fig. 2-1). The buildings had a square footprint, $207 \mathrm{ft} 2 \mathrm{in}$. $(63.14 \mathrm{~m})$ on a side with chamfered corners. From the 9 th to 107 th floors, the perimeter columns consisted of closely spaced built-up box columns. The service core at the building center was approximately $87 \mathrm{ft}$ by $137 \mathrm{ft}(26.5 \mathrm{~m}$ by $41.8 \mathrm{~m})$ and connected to the perimeter columns by a floor panel system that provided an essentially column-free office space; see Fig. 2-2. In addition to showing the location of perimeter and core columns, Fig. 2-2 describes the column numbering scheme used to identify each column on a given floor.

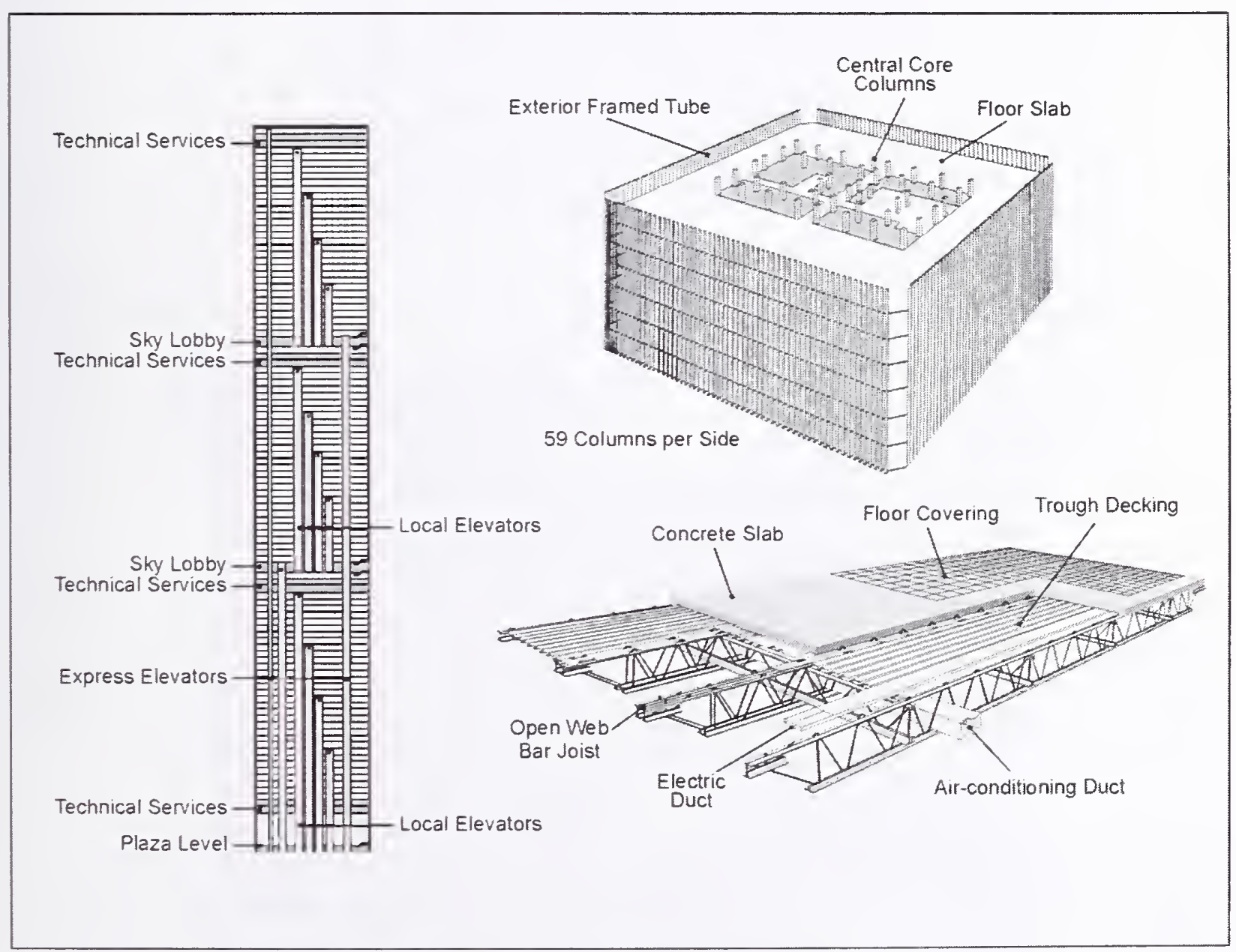

Figure 2-1. Schematic diagram of the tower structure. 


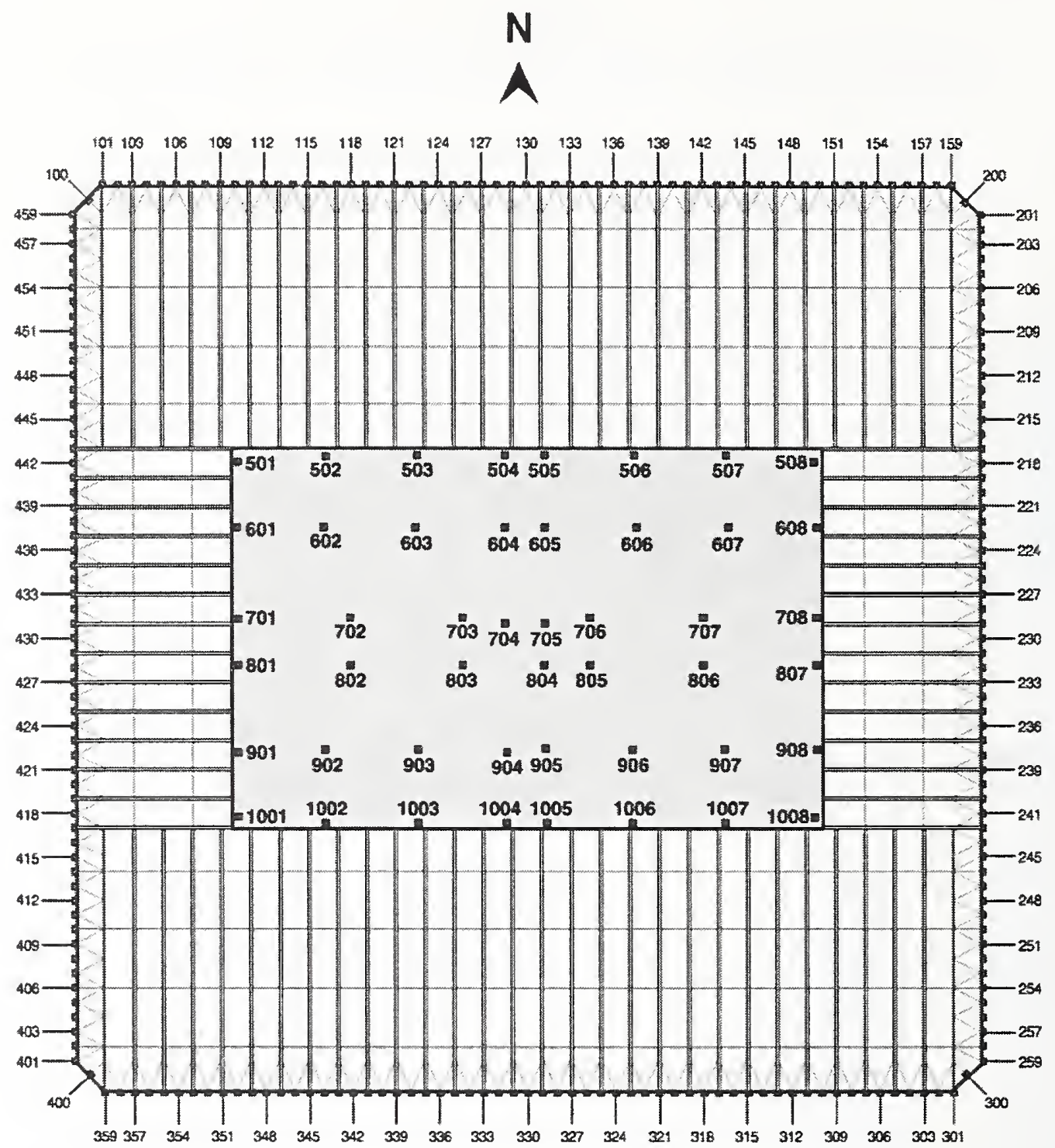

Figure 2-2. WTC tower floor plan and column numbers.

The WTC tower structural steel plans (SHCR 1967 ) point out the major structural elements of interest. The main features of structural interest are the perimeter columns, the core columns and associated framing, the trusses that supported the floors, and the connections between and within these elements. In addition, a "hat truss" located within the 107th to 110 th floors tied the core to the perimeter columns and provided a base for the television mast atop WTC 1 and support for a proposed mast atop WTC 2.

The structural steel drawings provide the location, cross-sections, and grade of steel (i.e., required minimum yield strength) for each of the thousands of structural elements in the buildings. In all, 14 different grades of steel were specified, ranging in yield strength from $36 \mathrm{ksi}$ to $100 \mathrm{ksi}$. In addition to yield strength requirements, Port of New York Authority (PONYA) documents provided by the Port Authority of New York and New Jersey (PANYNJ) specified allowable steels using ASTM International (ASTM) or other standards (details in Chapter 3 in this report). Requirements for bolts and welds are also given. 


\subsubsection{Perimeter Columns}

Between the 9th and 107th floors, the perimeter structure consisted of closely spaced, built-up box columns. Each building face consisted of 59 columns spaced at $40 \mathrm{in}$. (1.02 m). The columns were fabricated by welding plates of steel to form an approximately $14 \mathrm{in.}(0.36 \mathrm{~m})$ square section (Fig. 2-3). Adjacent columns were interconnected at each floor level by deep spandrel plates, typically 52 in. (1.32 m) deep (Fig. 2-4).
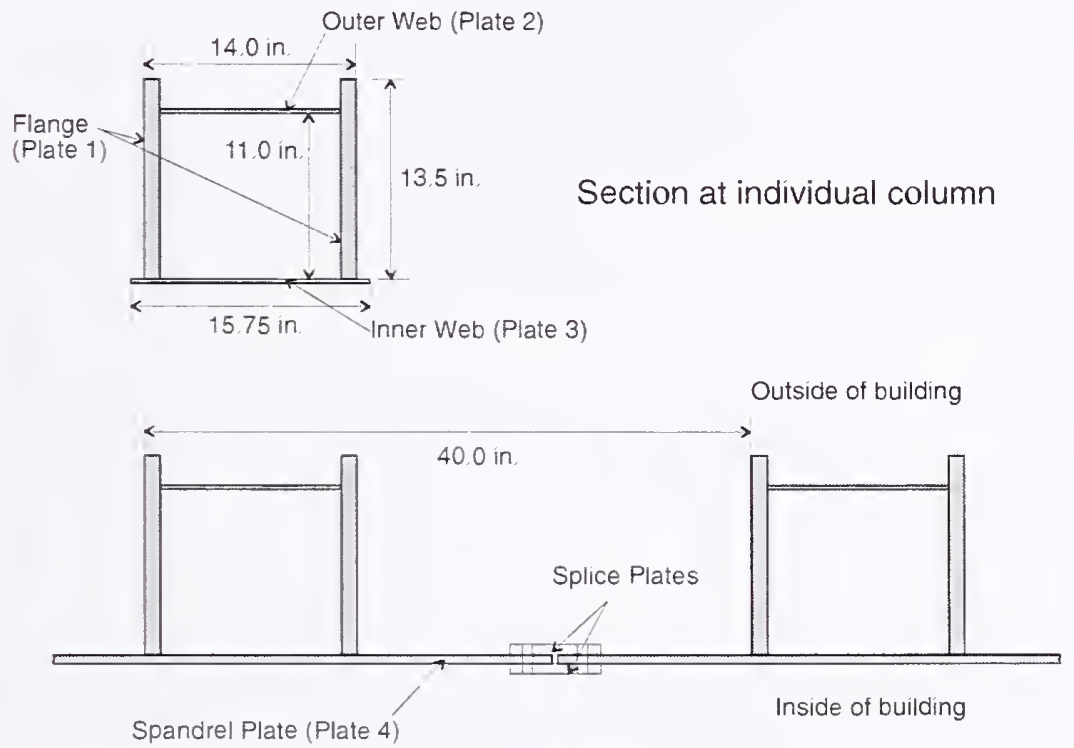

Section at spandrel

Figure 2-3. Cross-section of perimeter columns; sections with and without spandrels.
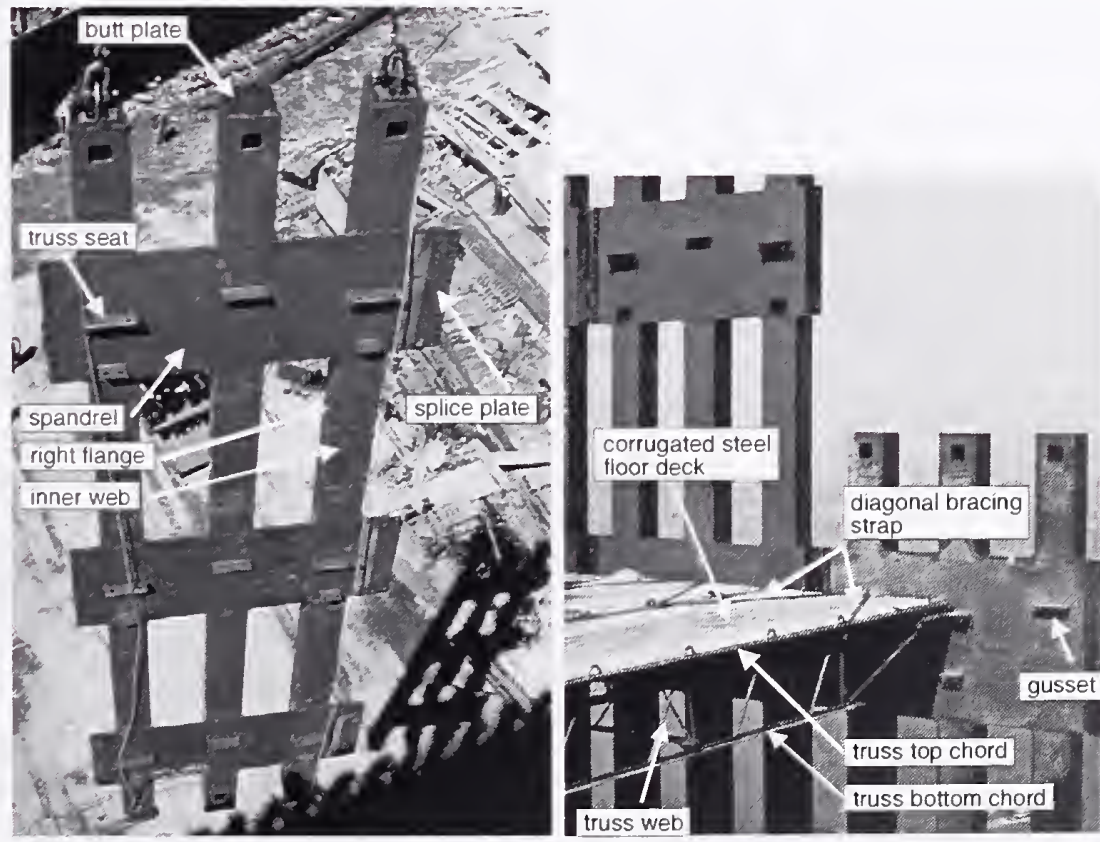

Source: Unknown. Enhanced by NIST.

Figure 2-4. Characteristic perimeter column panel consisting of three full columns connected by three spandrels. 
The perimeter columns were prefabricated into panels, typically three stories tall and three columns wide (Fig. 2-4). Other than at the mechanical floors, panels were staggered (Fig. 2-5) so that only one-third of the units were spliced (i.e., connected) in any one story. Heavy end, or "butt" plates with $F_{y}=50 \mathrm{ksi}$ and $1.375 \mathrm{in}$. to $3 \mathrm{in}$. ( $3.5 \mathrm{~mm}$ to $7.6 \mathrm{~mm}$ ) thick were welded to the top and bottom of each column. Fillet welds were used inside the columns along three edges, with a groove weld on the fourth, outside edge. During erection, abutting spandrels were bolted together, and columns were bolted to the adjacent columns, all using ASTM A 325 bolts, except for the heaviest butt plates, which used ASTM A 490 bolts

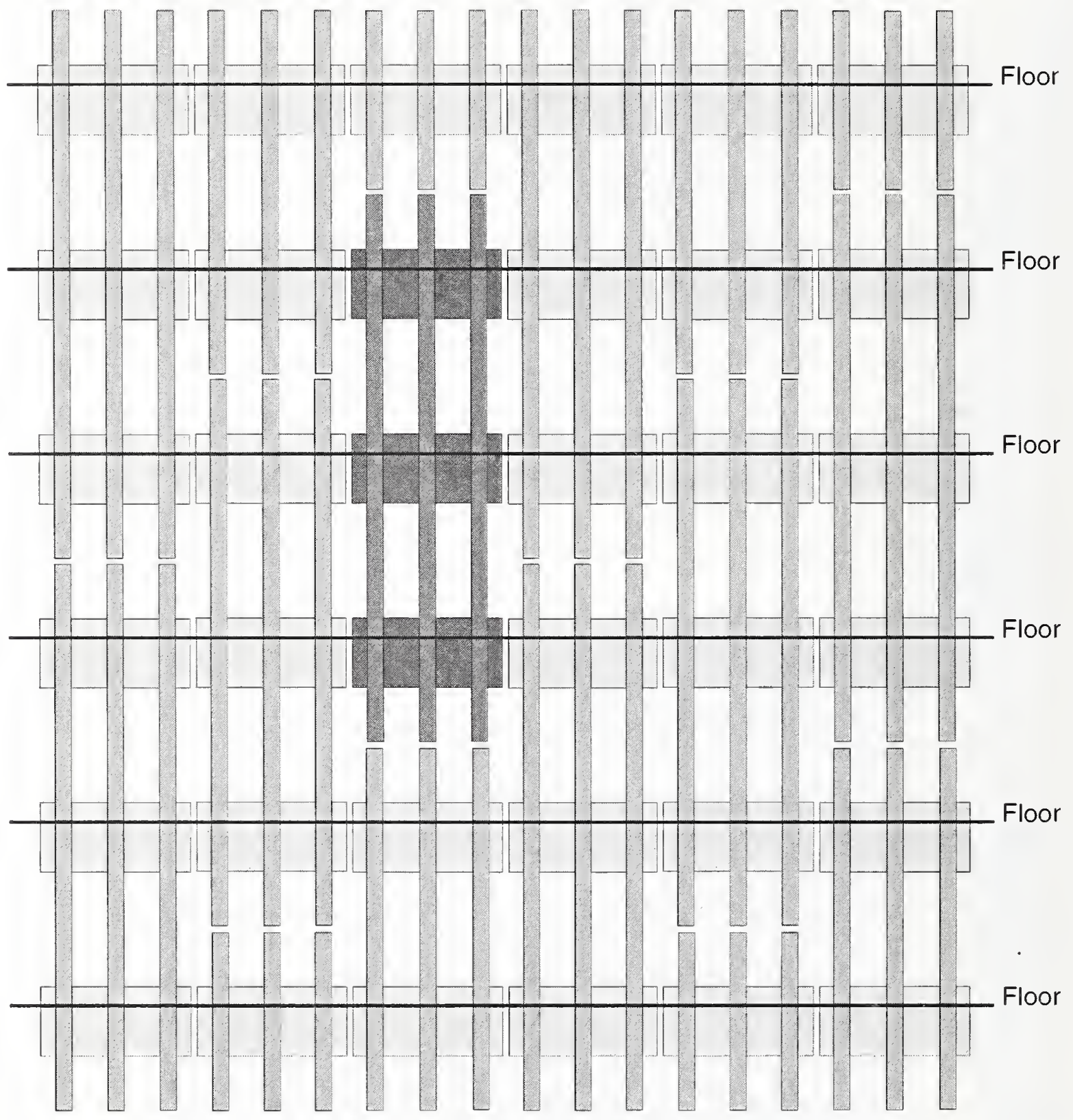

Figure 2-5. Partial elevation of exterior bearing-wall frame showing exterior wall module construction. Highlighted panel is three stories tall (36 ft) and spans four floors. Distance between panels has been exaggerated. 
Fourteen grades of steel were specified in the design documents for the perimeter columns, with minimum yield strengths of $(36,42,45,46,50,55,60,65,70,75,80,85,90$, and 100) ksi. Twelve grades of steel were specified for the spandrels, with the same strength levels as the columns but without the two highest strength steels. The structural steel drawings indicate that the flanges and webs of a given column section consist of a single grade (i.e., minimum yield strength) of steel, but each column and spandrel within a single prefabricated panel could be fabricated from different grades of steel.

Columns in the upper stories were typically fabricated of lighter gauge steel, as thin as 0.25 in. $(6.35 \mathrm{~mm})$, with the grade of steel dictated by the calculated gravity and wind loads. In this manner the gravity load on the lower stories was minimized. In the lower stories the perimeter column flanges were often more than 2 in. $(51 \mathrm{~mm})$ thick.

The spandrels formed an integral part of the columns: there was no inner web plate at spandrel locations. Spandrels were generally specified with a yield strength lower than that of the webs and flanges, as well as a heavier gauge than the adjacent inner webs.

\subsubsection{Core Columns}

Core columns were of two types: welded box columns and rolled wide flange (WF) shapes (Fig. 2-6). The columns in the lower floors were primarily very large box columns as large as $12 \mathrm{in}$. by $52 \mathrm{in}$. $(0.30 \mathrm{~m}$ by $1.32 \mathrm{~m})$ composed of welded plates up to $7 \mathrm{in}$. $(178 \mathrm{~mm})$ thick. In the upper floors the columns shifted to the rolled WF shapes. The transition floors are indicated in Fig. 2-6 for each of the core columns. Core columns were typically spliced at three-story intervals. The splices in the impact and fire zones were at floors $75,77,80,83,86,89,92,95,98$, and 101. Diagonal bracing was used at the mechanical floors and in the area of the hat truss. Core box columns were $36 \mathrm{ksi}$ or $42 \mathrm{ksi}$. Core wide flange columns were specified to be one of four grades, but were primarily $36 \mathrm{ksi}$ and $42 \mathrm{ksi}$ steel; only about 1 percent of all the core columns were made of $45 \mathrm{ksi}$ or $50 \mathrm{ksi}$ steel.

The core area was framed conventionally with beams. There were numerous openings in the core area floor for elevators and stairwells. Since fewer elevators were needed at the upper floors, part of the core area was not needed for services. In Fig. 2-7, the dashed line shows the perimeter of the core, and shaded areas indicate typical enclosed areas for elevators and other services.

\subsubsection{Flooring System}

In the great majority of floors, the floor area outside the central core was supported by a series of 29 in. $(0.74 \mathrm{~m})$ deep, composite open web bar joists ("floor trusses") that spanned between the core and perimeter wall (Fig. 2-8). At the core, the floor trusses were bolted to seats generally attached to channels that ran continuously along the core columns. At the perimeter columns, the floor trusses were bolted and then welded to seats, mounted on spandrels at every other column. The floor trusses were approximately $60 \mathrm{ft}(18.3 \mathrm{~m})$ or $35 \mathrm{ft}(10.7 \mathrm{~m})$ long (depending upon the relative orientation of the building core), spaced at $6 \mathrm{ft} 8 \mathrm{in}$. $(2.0 \mathrm{~m})$. There were of dozens of variants. 

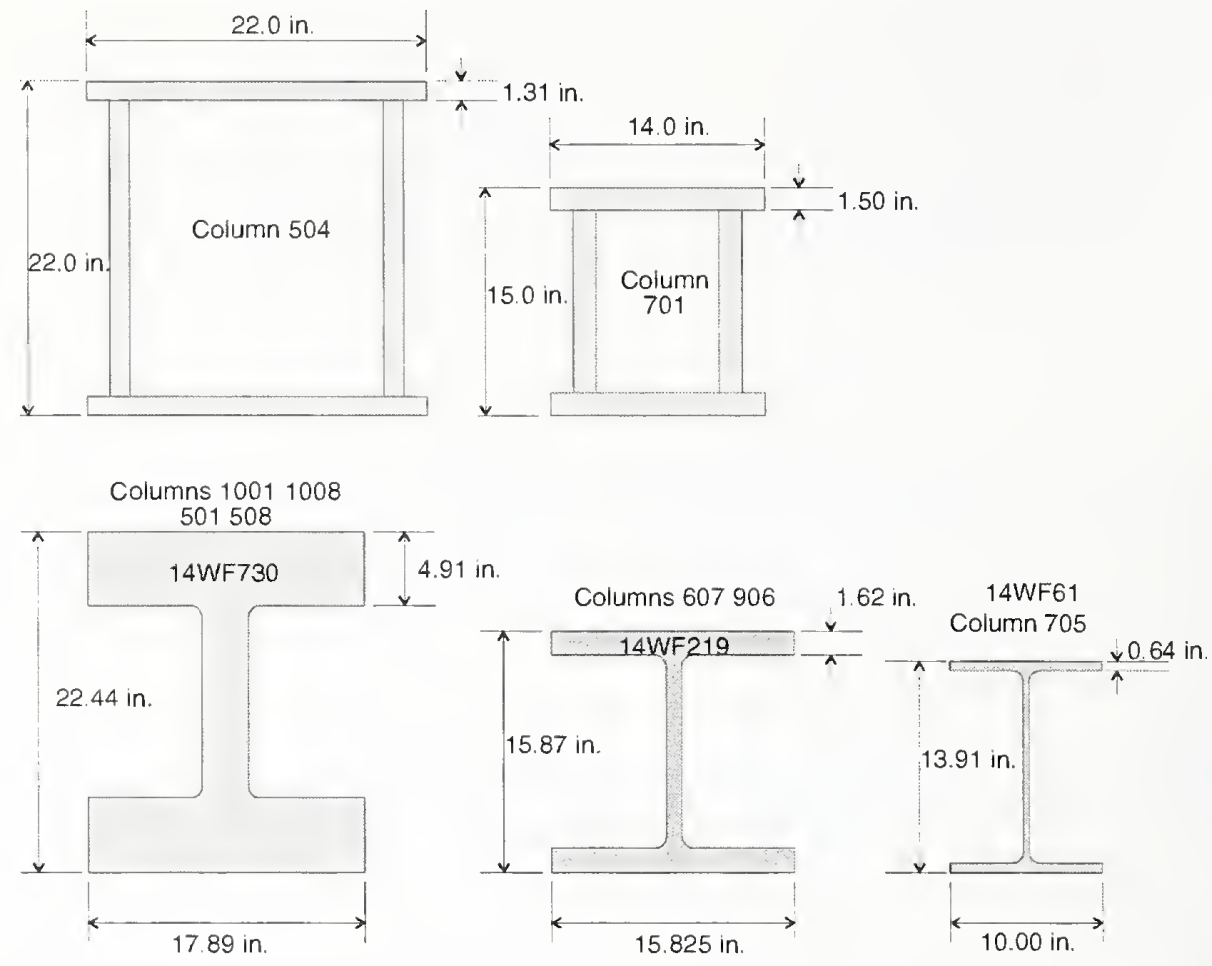

Figure 2-6. Typical welded box members and rolled wide flange shapes used for core columns between the 83rd and 86th floors (to scale).

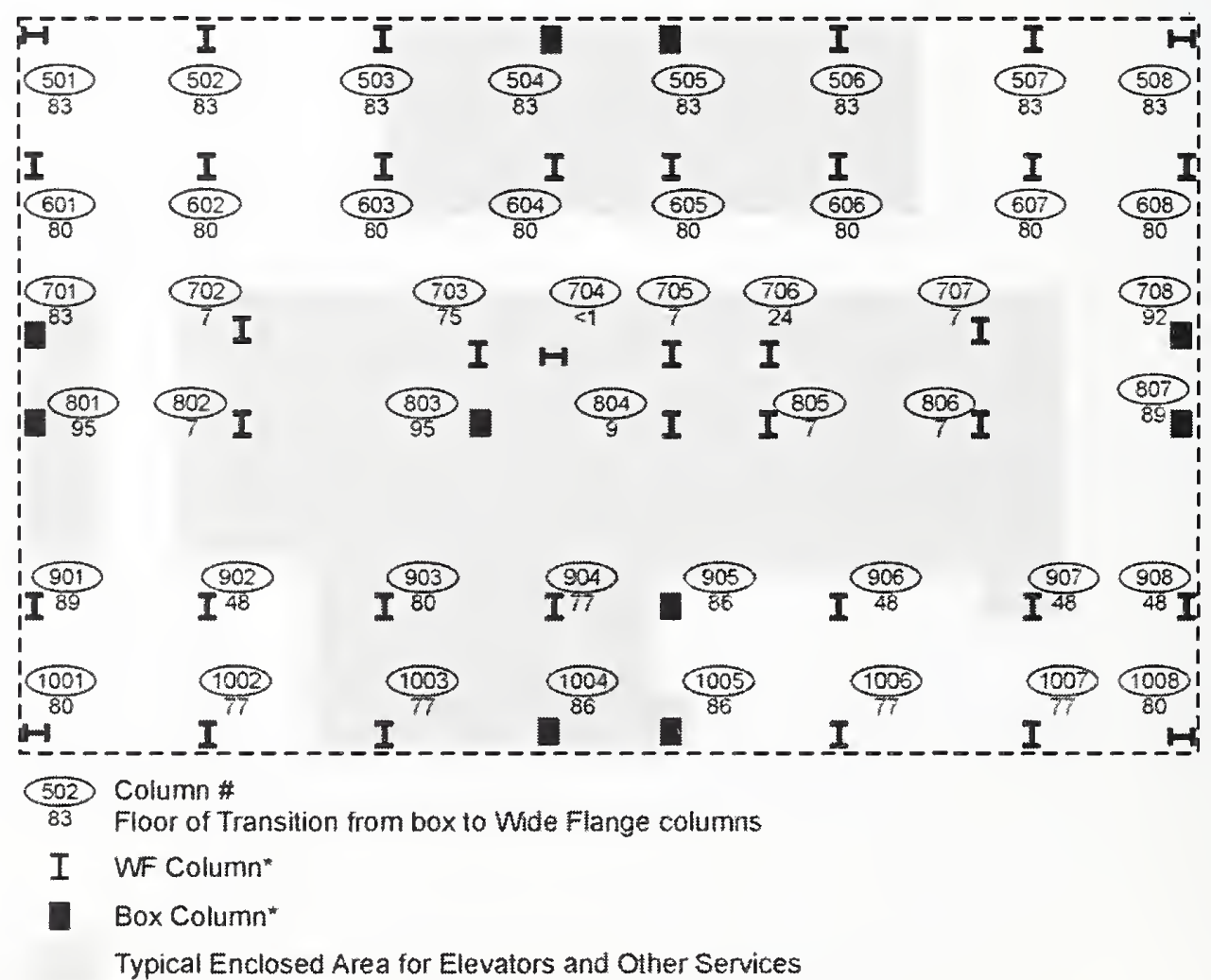

"Shape of Column at the 84 th Floor

Figure 2-7. Core column layout in WTC towers. 


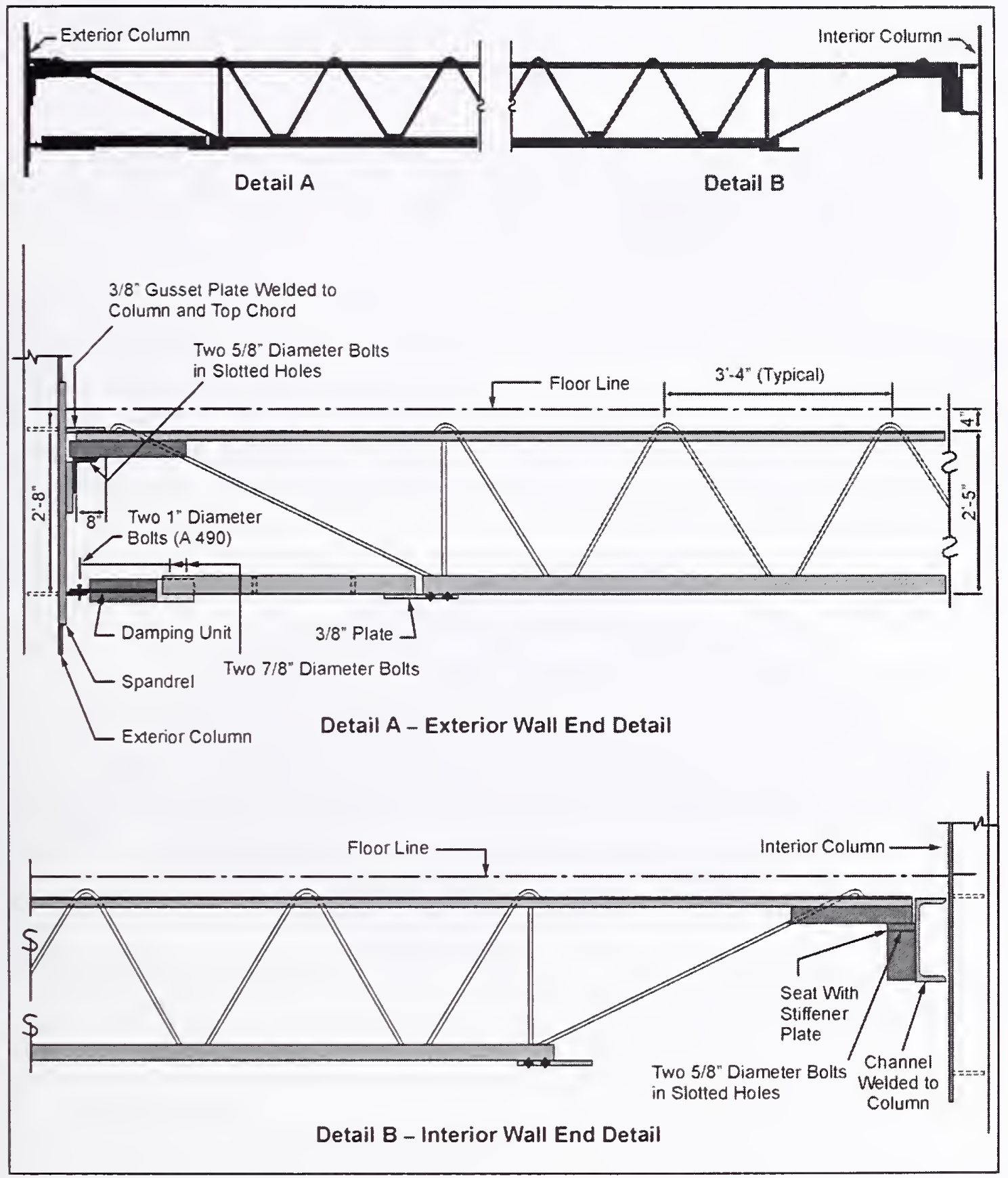

Figure 2-8. Schematic diagram of a floor truss.

The prefabricated floor modules were typically $20 \mathrm{ft}(6.1 \mathrm{~m})$ wide, containing two sets of doubled trusses in the interior and a single truss along each edge. Thus, each seat supported either a double truss within a floor panel, or two single trusses from adjacent floor panels. In addition, the bottom chord of each pair of trusses was attached to perimeter spandrels with visco-elastic dampers. Bridging trusses ran perpendicular to the main bar trusses and were spaced at $13 \mathrm{ft} 4 \mathrm{in} .(4.06 \mathrm{~m})$. The floor panels were covered with a corrugated steel floor deck that rested on the bridging trusses. Flutes in the deck ran parallel to the main trusses. Once in place, $4 \mathrm{in}$. $(100 \mathrm{~mm})$ of lightweight concrete was poured for the floor. Figure 2-4 shows an assembled floor panel before the concrete floor was poured. 
The minimum yield strength of the steel for the floor trusses was specified to be $50 \mathrm{ksi}$ "unless otherwise noted." In practice, several of the designs specified $36 \mathrm{ksi}$ steel as well as $50 \mathrm{ksi}$ steel (see Sec. 3.3.1 for complete details).

All seats were specified to be of $36 \mathrm{ksi}$ minimum yield strength. There were over 30 varieties of perimeter seats, with various thicknesses from $3 / 8$ to $7 / 8 \mathrm{in}$. in $1 / 8 \mathrm{in}$. increments $(9.5 \mathrm{~mm}$ to $22.2 \mathrm{~mm}$ in $3.2 \mathrm{~mm}$ increments). Core seats were $7 / 16 \mathrm{in}$., $1 / 2 \mathrm{in} ., 5 / 8 \mathrm{in}$., or $3 / 4 \mathrm{in}$. thick $(11.1 \mathrm{~mm}, 12.7 \mathrm{~mm}$, $15.9 \mathrm{~mm}$, or $19 \mathrm{~mm}$ ).

Certain floors outside the core were supported by rolled structural steel shapes rather than trusses. These included the mechanical floors and the floors just above the mechanical floors (e.g., floors 75, 76, and 77). Beam framing was typically $W 27^{2}$ beams in the long span region and W1 6 beams in the short direction with beams spaced at $40 \mathrm{in}$. The floor was $5.75 \mathrm{in}$. thick, normal-weight concrete poured on a 1.5 in. fluted steel deck, acting compositely with the steel beams. The concrete on the beam-framed floors above the mechanical floors was $8 \mathrm{in}$. thick, normal-weight concrete in the core area and $7.75 \mathrm{in}$. thick normal-weight concrete outside the core.

The floor in the core area was typically framed with rolled structural steel shapes acting compositely with formed concrete slabs.

\subsubsection{Floors 107 to 110}

At the top of each tower (floors 107 to the roof) a hat truss interconnected the core columns (Fig. 2-9). Diagonals of the hat truss were typically W12 or W14 wide flange members. In addition, four diagonal braces (18 in. by 26 in. box beams spanning the $35 \mathrm{ft}$ gap, and 18 in. by $30 \mathrm{in}$. box beams spanning the $60 \mathrm{ft}$ gap) and four horizontal floor beams connected the hat truss to each perimeter wall at the 108th floor spandrel. The hat truss was designed to provide a base for antennae atop each tower, although only the WTC 1 antenna was actually built.

Perimeter columns for floors 107 to 110 also differed from the lower floors and were alternating small tube columns or wide flange columns, with the wide flange columns supporting the floor system.

2 The "W" in W27 beam denotes the shape of the beam (see Fig. 2-6). The number following the "W" denotes the weight of the beam in pounds per foot. 

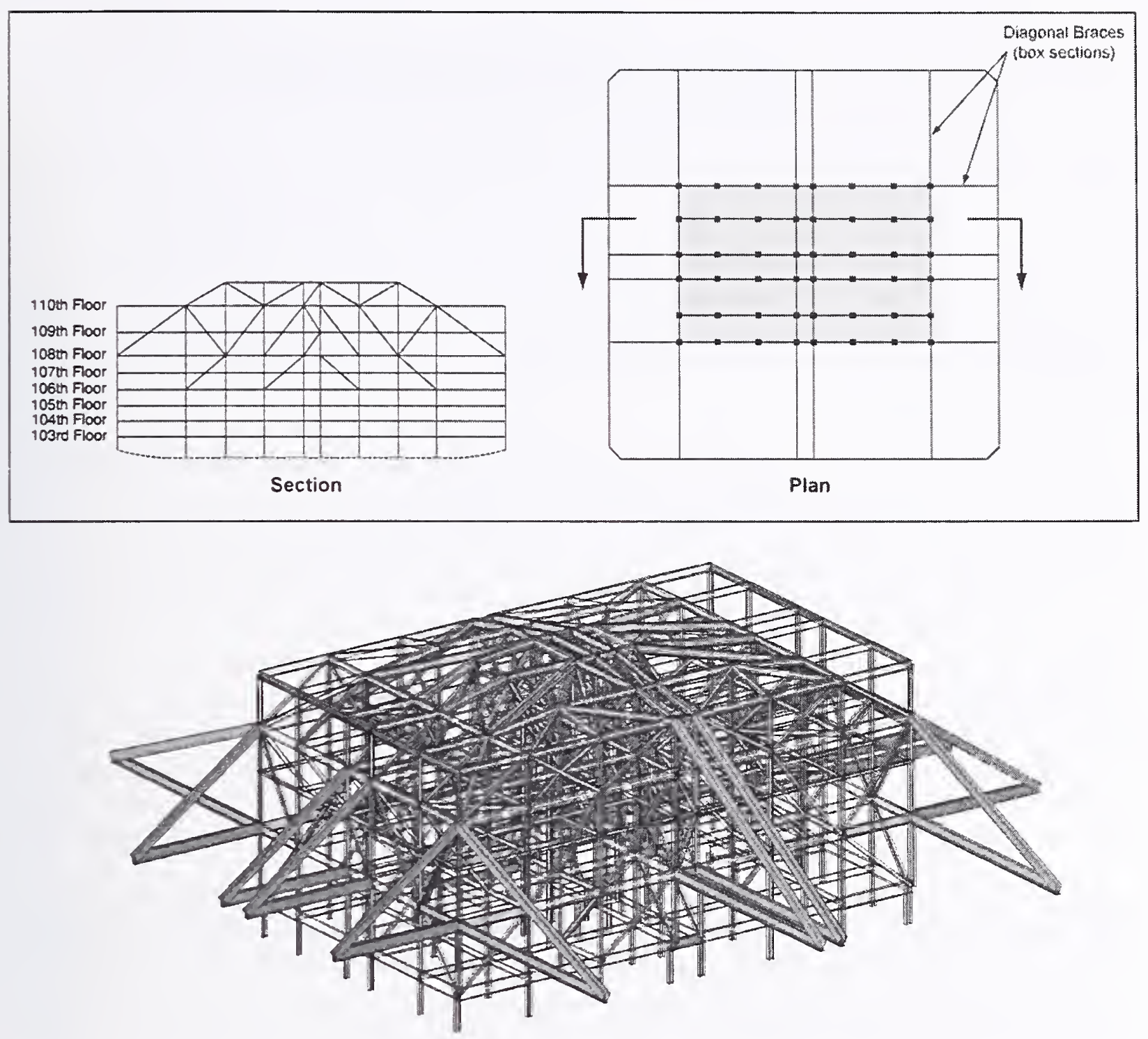

Figure 2-9. Hat truss in upper floors.

\subsubsection{Impact Zone}

The impact zones of the two towers are of particular interest, and special testing of the steels in this rcgion will be conducted. High strain-rate mechanical tests and high-temperature mechanical property tests will focus on those steels most prominent in the impact zones, as indicated below.

In WTC 1, the perimeter columns torn out or otherwise damaged by the airplane impact (as judged from photographs of the building) were predominantly spccified as $55 \mathrm{ksi}$ and $60 \mathrm{ksi}$ stecl. In WTC 2, most damaged columns were specified in the $55 \mathrm{ksi}$ to $65 \mathrm{ksi}$ range, though there was a wide range of steel grades involved. Table 2-1. Summarizes the steel grades in the perimeter columns damaged by the impact. In the table, the impact zone is defined as floors 94 to 98 in WTC 1 and floors 78 to 83 in WTC 2. Although the extremities of the airplanes extended onto surrounding floors, these are the floors over which the airplanes penetrated into the buildings. 
Table 2-1. Number of WTC 1 and 2 perimeter columns damaged by aircraft impact.

\begin{tabular}{|c|c|c|c|c|c|c|c|c|c|c|}
\hline Tower & \multicolumn{10}{c|}{ Column Design Minimum Yield Strength $\boldsymbol{F}_{\boldsymbol{y}}$ (ksi) } \\
\hline & 50 & 55 & 60 & 65 & 70 & 75 & 80 & 85 & 90 & 100 \\
\hline WTC 1 & 3 & 27 & 17 & 5 & - & - & - & - & - & - \\
\hline WTC 2 & 1 & 6 & 13 & 16 & 2 & 1 & 1 & - & 2 & 1 \\
\hline
\end{tabular}

The number of core columns damaged by the impact is not known. In the WTC 1 impact zone, the core columns were almost entirely wide flange shapes. In the WTC 2 impact zone, the core columns were a mix of box and wide flange shapes. As is typical of all core columns, the steel was predominantly specified as $36 \mathrm{ksi}$ and $42 \mathrm{ksi}$ minimum yield strength. Table 2-2 describes the distribution of core column types in the impact zones.

Table 2-2. Number of core columns with a given minimum yield strength within the floors penetrated by the aircraft.

\begin{tabular}{|l|c|c|c|c|c|c|c|c|}
\hline Column Type & \multicolumn{9}{|c|}{ Yield Strength $F_{y}$ (ksi) } \\
\hline & \multicolumn{4}{|c|}{ WTC 1 (floors 94 to 98) } & \multicolumn{4}{c|}{ WTC 2 (floors 78 to 83) } \\
\hline & 36 & 42 & 45 & 50 & 36 & 42 & 45 & 50 \\
\hline Box & 0 & 3 & - & - & 38 & 15 & - & - \\
\hline Wide flange & 88 & 44 & 3 & 3 & 81 & 6 & 0 & 1 \\
\hline
\end{tabular}

Note: Core columns were three stories tall and were spliced at floors $77,80,83,86,89,92,95$, and 98 . The splice is several feet above the floor at the story indicated. Therefore, in the WTC 1 impact zone, there were three sets comprising 141 individual columns.

\subsubsection{Floors Involved in Post-Impact Fires}

Special attention was given to characterizing the performance of the structural steel found in floors engaged in the post-impact fires. The steels most vulnerable to heat from the fires were located in the zone damaged by the impact since those members were already under additional loads. Table 2-3 lists the perimeter column types and grades of steel within these floors, defined here as floors 92 to 100 for WTC 1, and floors 77 to 83 for WTC 2. Table 2-4 lists this information for the core columns.

Table 2-3. Number of perimeter columns of specified grades in floors with significant fire.

\begin{tabular}{|c|c|c|c|c|c|c|c|c|c|c|c|c|c|}
\hline & \multirow[b]{2}{*}{ Floors } & \multicolumn{12}{|c|}{ Perimeter Column Design Minimum Yield Strength $F_{y}(\mathrm{ksi})$} \\
\hline & & 45 & 46 & 50 & 55 & 60 & 65 & 70 & 75 & 80 & 85 & 90 & 100 \\
\hline WTC 1 & 92 to 100 & 0 & 1 & 26 & 225 & 246 & 196 & 122 & 83 & 40 & 16 & 7 & 16 \\
\hline WTC 2 & 77 to 83 & 1 & 3 & 34 & 217 & 255 & 88 & 29 & 25 & 26 & 40 & 91 & 105 \\
\hline
\end{tabular}

Table 2-4. Number of core columns of specified grades in floors with significant fire.

\begin{tabular}{|l|c|c|c|c|c|c|c|c|}
\hline \multirow{2}{*}{ Column Type } & \multicolumn{6}{|c|}{ Yield Strength $F_{\mathbf{y}}(\mathrm{ksi})$} \\
\cline { 2 - 10 } & \multicolumn{3}{|c|}{ WTC 1 (floors 92 to 100) } & \multicolumn{4}{c|}{ WTC 2 (floors 77 to 83) } \\
\hline & 36 & 42 & 45 & 50 & 36 & 42 & 45 & 50 \\
\hline Box & 0 & 7 & - & - & 69 & 16 & - & - \\
\hline Wide flange & 115 & 58 & 3 & 5 & 86 & 13 & 1 & 3 \\
\hline
\end{tabular}




\section{Chapter 3 \\ CONTEMPORANEOUS STEEL SPECIFICATIONS}

\section{$3.1 \quad$ INTRODUCTION}

This section integrates information from many sources on the steels used in the World Trade Center (WTC) and has two goals. First, contemporaneous (1960s era) American and Japancse steel specifications are summarized. Second, relevant information on steel properties from the construction documents and open literature sources is presented.

The report approaches these goals are approached from several directions. As is common practice, the structural engineering plans (obtained from the Port Authority of New York and New Jersey [PANYNJ or Port Authority]) only specify the minimum yield strengths and dimensions of the beams and columns. The steel contracts that the Port Authority (PONYA 1967, Ch. $2 \S$ ) awarded for the fabrication provided the specifications for the allowable steels to meet those minimum yield strengths. Those contracts allowed the fabricators to use steels that conformed to certain ASTM International (ASTM) Standard Specifications. In addition, the contracts also permitted the fabricators to use certain proprictary steels from U.S. steel mills. These were required to conform to specific, dated and published data sheets that the steel mills provided. Finally, the contracts also allowed other proprietary steels not listed in the contract, provided that the Port Authority chief engineer of the project reviewed and formally approved their specifications (PONYA 1967, Clause 1). In all cases, the steels required extensive documentation to be acceptable for use.

This chapter focuses on the steels used in the area of the impact and fire: the floor panels, the perimeter columns, the welded core box columns, and the rolled core columns, fabricated by Laclede, Pacific Car and Foundry, Stanray Pacific, and Montague-Betts, respectively. It does not consider any of the sections of the buildings remote from the impact and fire sites, so fabricators of sections bclow the 9th floor (Mosher, Drier, Levinson, Pittsburgh-Des Moines, and Atlas) are not addressed, although Appendix A provides some background information on these companies.

In this document, "contemporaneous" rcfers to the standards in effect at the time of construction, in contrast to contemporary (or present-day) standards. ASTM standards are modified and renewed at regular intervals, so the current requirements of a standard may not have been in force during the WTC era. This distinction is also important because historical versions of standards can be difficult to locate. Appendix B summarizes the generally minor differences between the contemporaneous and contemporary versions of the relevant standards.

\subsection{STANDARDS CALLED FOR IN THE STEEL CONTRACTS}

The Port Authority had a generic contract that listed allowable steel standard specifications, which went to all the fabricators. Generally, it specified that a given steel was acceptable for use if it conformed to one of a list of ASTM standards that were in force during September 1967. It also allowed several steels that were modifications of these ASTM standards. In addition, it allowed a number of proprietary steels 
made by U.S. steel mills. Finally, it allowed the use of other proprietary steels after formal approval by the Project Engineer, an employee of the Port Authority. It was by this last method that Pacific Car and Foundry (PC\&F) received approval to use the Japanese steels in the perimeter columns.

It is important to remember that an ASTM standard can admit a wide variety of steel compositions and strengths. A specific steel might be capable of meeting several distinct ASTM steel standards. For instance, ASTM A 36 only specifies a minimum $36 \mathrm{ksi}$ yield strength, an upper and lower tensile strength and carbon, mangancse, silicon, phosphorus, and sulfur contents. Many high-strength low-alloy steels designed to meet other ASTM structural steel standards (e.g., A 572, A 242) will also meet A 36. Simply identifying a specific steel as meeting a given ASTM standard will not uniquely identify its composition or mechanical properties.

In terms of shapes and tolerances, all the steel was required to meet ASTM A 6, "General Requirements for Delivery of Rolled Steel Plates..." This standard has evolved in the past thirty years. One significant difference between current and contemporaneous versions is that the 1966 standard made no allowances for chemistry deviations. Instead these deviations, the so-called check analyses, were stated in the individual steel standards. Currently those allowables have been moved out of the individual standards and into A 6.

\subsubsection{Steels}

Table 3-1 summarizes the allowable steels listed in the contract (in "Chapter 2 (Materials)") between the Port Authority and all the fabricators. Note that it does not list ASTM A 572, a common, current standard for niobium-vanadium structural steels, which was established only in 1966. The proprietary steels allowed by the contract do include U.S.S. EX-TEN and Bethlehem V-series, however. These steels would conform to ASTM A 572, which was under development in that era. Table 3-2 and Table 3-3 summarizes the relevant structural steel specifications from the WTC construction era, including data on the various "modified" standards allowed in the Materials chapter of the fabricators' contracts.

Although Japanese steel mills supplied much of the steel, NIST has found no evidence that the Port Authority or the fabricators ever referred to any Japanese (JIS) standards. Table 3-4 summarizes the relevant Japanese standards from the era. They not as detailed as the corresponding ASTM steel standards, and mostly just specify minimum yield strength and maximum carbon content.

\subsubsection{Fasteners}

Section 4.2 .4 covers fastener standards. 
Table 3-1. Steels specified as acceptable by the Port Authority in its contract with steel fabricators.

\begin{tabular}{|c|c|c|}
\hline Standard & $F_{y}(\mathrm{ksi})$ & Description of Standard \\
\hline \multicolumn{3}{|r|}{ Structural Steels } \\
\hline A 36 & 36 & Structural steel \\
\hline A 242 & 50 & High-strength structural steel \\
\hline A 440 & 50 & High-strength structural steel \\
\hline A 441 & 50 & High-strength manganese vanadium steel \\
\hline A 441 modified $^{a}$ & 50 & As A 441 with $\mathrm{Cr}$ and increased $\mathrm{Cu}$ \\
\hline A 514 & 100 & Quenched and tempered alloy steel plate for welding \\
\hline A 514 modified & 100 & As A 514, but $T S$ requirements waived \\
\hline USS CON PAC & & Grades 70 and 80 \\
\hline Bethlehem V series & & Grades $42,45,50,55,60,65$ \\
\hline Lukens & & Grades $45,50,55,60,80$ \\
\hline USS EX-TEN & & Grades $42,45,50,55,60,65,70$ \\
\hline USS COR-TEN & & "considered to conform to A 441 modified" \\
\hline Lukens COR-TEN & & "considered to conform to A 441 modified" \\
\hline \multicolumn{3}{|r|}{ Pressure Vessel Steels } \\
\hline A 302 & & Manganese molybdenum steel for pressure vessels \\
\hline \multicolumn{3}{|l|}{ A 302 modified } \\
\hline A 533 & & Mn-Mo and Mn-Mo-Ni steels for pressure vessels \\
\hline \multicolumn{3}{|l|}{ A 533 modified } \\
\hline A 542 & & Cr-Mo steel for pressure vessels \\
\hline
\end{tabular}

a. Apparently (Irving 1968) "A 441 modified" was a catch-all term for a group of steels that were codified in 1968 under ASTM A 588 "High-Strength Low-Alloy Structural Steel with 50,000 psi Minimum Yield Point to 4 in. Thick."

Key: $\mathrm{Cr}$. chromium; $\mathrm{Cu}$, copper; $F_{y}$, yield strength; $\mathrm{Mn}$, manganese; Mo, molybdenum; Ni, nickel; TS, tensile strength. 
Table 3-2. Summary of mechanical properties from relevant ASTM structural steel standards from WTC era.

\begin{tabular}{|c|c|c|c|c|c|c|}
\hline Standard & Title & $\begin{array}{l}F_{y} \\
\text { Min. } \\
\text { (ksi) }\end{array}$ & $\begin{array}{l}\text { TS } \\
\text { Min. } \\
\text { (ksi) }\end{array}$ & $\begin{array}{c}T S \\
\text { Max. } \\
\text { (ksi) }\end{array}$ & $\begin{array}{c}E l_{r} \\
\text { Min. } \\
(\%)\end{array}$ & Notes \\
\hline A $36-66^{a}$ & Structural steel & 36 & 58 & 80 & 20 & $\begin{array}{l}\text { For shapes; plates have higher } \mathrm{C}, \mathrm{Mn} \text {, } \\
\text { and Si requirements }\end{array}$ \\
\hline A $242-66^{\text {a }}$ & $\begin{array}{l}\text { High-strength low-alloy structural } \\
\text { steel }\end{array}$ & 50 & 70 & & 18 & $\begin{array}{l}\text { Plates and bars } t<=0.75 \text { in.; Group } \\
1 \& 2 \text { shapes }\end{array}$ \\
\hline A $440-67^{2}$ & High-strength structural steel & 50 & 70 & & 18 & $\begin{array}{l}\text { Plates and bars } t<=0.75 \text { in.; Group } \\
1 \& 2 \text { shapes }\end{array}$ \\
\hline A $440-67^{a}$ & High-strength structural steel & 46 & 67 & & 19 & $\begin{array}{l}\text { Plates and bars } 0.75 \text { in. }<t<=1.5 \text { in.; } \\
\text { Group } 3 \text { shapes; elongation reductions } \\
\text { based for } t>0.75 \mathrm{in.}\end{array}$ \\
\hline A $440-67^{a}$ & High-strength structural steel & 42 & 63 & & 16 & $\begin{array}{l}\text { Plates and bars } 1.5 \text { in. }<t<=4 \text { in.; } \\
\text { Group } 4 \& 5 \text { shapes.; elongation } \\
\text { reductions for } t>3.5 \mathrm{in.}\end{array}$ \\
\hline A $441-66^{a}$ & $\begin{array}{l}\text { High-strength low-alloy structural } \\
\text { manganese vanadium steel }\end{array}$ & 50 & 70 & & 18 & $\begin{array}{l}\text { Plates and bars } t<=0.75 \text { in.; Group } \\
1 \& 2 \text { shapes }\end{array}$ \\
\hline $\begin{array}{l}\text { A } 441- \\
\text { modified }^{2}\end{array}$ & As A 441 , but modified by PONYA & 50 & 70 & & 19 & $\begin{array}{l}\text { Plates \& bars } 0.75 \text { in. }<=t<=4 \text { in.; } \\
\text { Group } 1,2,3 \text { shapes }\end{array}$ \\
\hline A $441-66^{\mathrm{a}}$ & $\begin{array}{l}\text { High-strength low-alloy structural } \\
\text { manganese vanadium steel }\end{array}$ & 46 & 67 & & 19 & $\begin{array}{l}\text { Plates and bars } 0.75 \text { in. }<t<=1.5 \mathrm{in} . \\
\text { Group } 3 \text { shapes.; elongation } \\
\text { minimums relaxed for } t>0.75 \mathrm{in} .\end{array}$ \\
\hline A $441-66^{a}$ & $\begin{array}{l}\text { High-strength low-alloy structural } \\
\text { manganese vanadium steel }\end{array}$ & 42 & 63 & & 16 & $\begin{array}{l}\text { Plates and bars } 1.5 \text { in. }<t<=4 \text { in.; } \\
\text { Group } 4 \& 5 \text { shapes }\end{array}$ \\
\hline A $441-66^{3}$ & $\begin{array}{l}\text { High-strength low-alloy structural } \\
\text { manganese vanadium steel }\end{array}$ & 40 & 60 & & & $\begin{array}{l}\text { Plates and bars } 4 \text { in. }<t<=8 \text { in.; } \\
\text { elongations on } 2 \text { in. GL }\end{array}$ \\
\hline A $514-65^{a}$ & $\begin{array}{l}\text { High-yield-strength, quenched and } \\
\text { tempered alloy steel plate, suitable for } \\
\text { welding }\end{array}$ & 100 & 115 & 135 & 18 & $t<=0.75 \mathrm{in}$ \\
\hline A $514-65^{a}$ & $\begin{array}{l}\text { High-yield-strength, quenched and } \\
\text { tempered alloy steel plate, suitable for } \\
\text { welding }\end{array}$ & 100 & 115 & 135 & 18 & 0.75 in. $<t<=2.5$ in. \\
\hline A $514-65^{a}$ & $\begin{array}{l}\text { High-yield-strength, quenched and } \\
\text { tempered alloy steel plate, suitable for } \\
\text { welding }\end{array}$ & 90 & 105 & 135 & 17 & 2.5 in. $<t<=4$ in. \\
\hline $\begin{array}{l}\text { A 5 14- } \\
\text { modified }^{\text {a }}\end{array}$ & & 100 & $\mathrm{x}$ & $\mathrm{x}$ & $\begin{array}{l}\text { See } \\
\text { std. }\end{array}$ & $\begin{array}{l}\text { As A } 514 \text {, but } T S \text { waived in PONYA } \\
\text { steel contract }\end{array}$ \\
\hline A $529-64$ & $\begin{array}{l}\text { Structural steel with } 42 \mathrm{ksi} \text { minimum } \\
\text { yield point }\end{array}$ & 42 & 60 & 85 & 19 & \\
\hline A $572-70$ & $\begin{array}{l}\text { High strength low-alloy columbium } \\
\text { vanadium steels of structural quality }\end{array}$ & 50 & 65 & & 18 & $\begin{array}{l}6 \text { grades: } F_{y}=(424550556065) \mathrm{ksi} \text {; } \\
\text { different } C \text { contents }\end{array}$ \\
\hline A $573-70$ & $\begin{array}{l}\text { Structural carbon steel plates of } \\
\text { improved toughness }\end{array}$ & 35 & 65 & 77 & 20 & 2 grades $65 \mathrm{ksi}$ or $70 \mathrm{ksi} T S$ \\
\hline A $588-70$ & $\begin{array}{l}\text { High-strength low-alloy structural } \\
\text { steel with } 50 \mathrm{ksi} \text { minimum yield point } \\
\text { to } 4 \text { in. thick }\end{array}$ & 50 & 70 & & 18 & 9 chemistries \\
\hline
\end{tabular}

a. Allowed by PONYA Steel contract, Chapter 2, "Materials."

Key: $\mathrm{C}$, carbon; $E l_{l}$, total elongation; $F_{y}$, specified minimum yield strength; $\mathrm{Mn}$, manganese; $\mathrm{Si}$, silicon; $T S$, tensile strength. 
Table 3-3. Summary of chemistry data from relevant ASTM structural steel standards from WTC era.

\begin{tabular}{|c|c|c|c|c|c|c|c|c|c|c|}
\hline \multirow[b]{2}{*}{ Standard } & \multicolumn{9}{|c|}{ Chemistry (mass \%) } & \multirow[b]{2}{*}{ Other/Notes } \\
\hline & $\begin{array}{c}\mathrm{C} \\
\text { Max. }\end{array}$ & $\begin{array}{l}\text { Mn } \\
\text { Max. }\end{array}$ & $\begin{array}{c}\mathrm{Si} \\
\text { Max. }\end{array}$ & $\mathrm{Ni}$ & $\mathrm{Cr}$ & $\begin{array}{c}\text { V } \\
\text { Min. }\end{array}$ & $\begin{array}{l}\mathrm{Cu} \\
\text { Min. }\end{array}$ & $\begin{array}{c}P \\
\text { Max. }\end{array}$ & $\begin{array}{c}\text { S } \\
\text { Max. }\end{array}$ & \\
\hline A 36-66 shapes & 0.26 & NR & $\overline{N R}$ & & & & 0.2 & 0.04 & 0.05 & Cu where specified \\
\hline $\begin{array}{l}\text { A36-66 plates with } \\
I \leq 0.75 \text { in. }\end{array}$ & 0.25 & NR & NR & & & & & 0.04 & 0.05 & $\mathrm{Cu}$ where specified \\
\hline $\begin{array}{l}\text { A } 36-66 \text { plates with } \\
0.75 \text { in. }<1 \leq 1.5 \text { in }\end{array}$ & 0.25 & $0.8-1.2$ & NR & & & & & 0.04 & 0.05 & $\mathrm{Cu}$ where specified \\
\hline $\begin{array}{l}\text { A } 36-66 \text { plates with } \\
1.5 \text { in. }<t \leq 2.5 \text { in }\end{array}$ & 0.26 & $0.8-1.2$ & $0.15-0.3$ & & & & & 0.04 & 0.05 & Cu where specified ${ }^{\mathrm{a}}$ \\
\hline A 242-66 & 0.22 & 1.25 & & & & & & & 0.05 & Type 1 \\
\hline A $242-66$ & 0.15 & 1.40 & & & & & & & 0.05 & Type 2 \\
\hline A $440-67$ & 0.28 & $1.1-1.6$ & 0.3 & & & & 0.2 & 0.06 & 0.05 & \\
\hline A 441-66 & 0.22 & $0.85-1.25$ & 0.3 & & & 0.02 & 0.2 & 0.04 & 0.05 & \\
\hline A 441-modified & 0.19 & $0.85-1.25$ & $0.15-0.3$ & & $0.4-0.65$ & 0.02 & $0.25-0.4$ & 0.04 & 0.05 & \\
\hline A 441-66 & 0.22 & $0.85-1.25$ & 0.3 & & & 0.02 & 0.2 & 0.04 & 0.05 & \\
\hline A $514-65$ & & & & & & & & & & $\begin{array}{l}8 \text { individual } \\
\text { chemistries, with } \mathrm{Cr} \text {, } \\
\text { Mo, } \mathrm{B}\end{array}$ \\
\hline A 529-64 & 0.27 & 1.2 & & & & & 0.2 & 0.04 & 0.05 & \\
\hline A $572-70$ & 0.22 & 1.35 & 0.3 & & & & & 0.04 & 0.05 & $\begin{array}{l}4 \text { variants with } \mathrm{Nb} \text { or } \\
\mathrm{Va} \text { or } \mathrm{Nb}+\mathrm{Va} \text {, or } \mathrm{V}+\mathrm{N}\end{array}$ \\
\hline A $573-70$ & 0.24 & $0.85-1.25$ & $0.15-0.30$ & & & & & 0.04 & 0.05 & \\
\hline A $588-70$ & & & & & & & & & & $\begin{array}{l}9 \text { individual } \\
\text { chemistries, generally } \\
\text { with } \mathrm{Cr}, \mathrm{Ni}, \mathrm{V}, \mathrm{Nb}\end{array}$ \\
\hline
\end{tabular}

a. A 36 plates have different requirements for thicker sections that include higher carbon allowables and slightly different manganese requirements.

Key: B, boron; C, carbon; $\mathrm{Cr}$, chromium; $\mathrm{Cu}$, copper; Mn, manganese; Mo, molybdenum; Nb, niobium; Ni, nickel; NR, no requirement; $\mathrm{P}$, phosphorus; $\mathrm{Si}$, silicon; $\mathrm{S}$, sulfur; $\mathrm{V}$, vanadium. 
Table 3-4. Summary of Japan Industrial Standard structural steel standards from 1974.

\begin{tabular}{|c|c|c|c|c|c|c|c|c|c|c|c|c|}
\hline Standard & Grade & $\begin{array}{c}F_{y} \\
\text { Min. } \\
\text { (ksi) }\end{array}$ & $\begin{array}{l}\text { TS } \\
\text { Min. } \\
(\mathrm{ksi})\end{array}$ & $\begin{array}{l}\text { TS } \\
\text { Max. } \\
\text { (ksi) }\end{array}$ & $\begin{array}{c}\mathrm{C} \\
\mathrm{Max} . \\
(\%)\end{array}$ & $\begin{array}{l}\text { Mn } \\
\text { Max. } \\
(\%)\end{array}$ & $\begin{array}{c}\text { Si } \\
\text { Max. } \\
(\%)\end{array}$ & $\begin{array}{l}\mathrm{Cr} \\
(\%)\end{array}$ & $\begin{array}{l}\mathrm{Cu} \\
\mathrm{Min} . \\
(\%)\end{array}$ & $\begin{array}{c}\text { P } \\
\text { Max. } \\
(\%)\end{array}$ & $\begin{array}{c}S \\
\operatorname{Max} . \\
(\%)\end{array}$ & Other \\
\hline \multirow{5}{*}{$\begin{array}{l}\text { JISG3106-73 Rolled } \\
\text { Steel for Welded } \\
\text { Structure }\end{array}$} & SM50a & 45 & 71 & 88 & 0.20 & 1.5 & 0.55 & & & 0.04 & 0.04 & $\begin{array}{l}\text { Add any element } \\
\text { "if necessary" }\end{array}$ \\
\hline & $\begin{array}{l}\text { SM50b } \\
\text { SM50c }\end{array}$ & 45 & 71 & 88 & 0.18 & & & & & 0.04 & 0.04 & $\begin{array}{l}\text { Add any element } \\
\text { "if necessary" }\end{array}$ \\
\hline & $\begin{array}{l}\text { SM50Ya } \\
\text { SM50Yb }\end{array}$ & 51 & 71 & 88 & 0.20 & 1.5 & 0.55 & & & 0.04 & 0.04 & $\begin{array}{l}\text { Add any element } \\
\text { "if necessary" }\end{array}$ \\
\hline & $\begin{array}{l}\text { SM53b } \\
\text { SM53c }\end{array}$ & 51 & 75 & 92 & & & & & & & & $\begin{array}{l}\text { Add any element } \\
\text { "if necessary" }\end{array}$ \\
\hline & SM58 & 65 & 82 & 104 & 0.18 & 1.5 & 0.55 & & & 0.04 & 0.04 & \\
\hline \multirow{2}{*}{$\begin{array}{l}\text { JIS G3114-73 Hot } \\
\text { Rolled Atmospheric } \\
\text { Corrosion Resistant } \\
\text { Steel for Welded } \\
\text { Structure }\end{array}$} & $\begin{array}{l}\text { SMA 50a } \\
\text { SMA50b } \\
\text { SMA50c }\end{array}$ & 51 & 71 & 88 & 0.19 & 1.4 & 0.75 & $0.3-1.2$ & $0.2-0.7$ & 0.04 & 0.04 & $\begin{array}{l}+\mathrm{Mo} \text { or } \mathrm{Nb} \text { or } \mathrm{Ni} \\
\text { or } \mathrm{Ti} \text { or } \mathrm{V} \text { or } \mathrm{Zr}\end{array}$ \\
\hline & SMA $58 \mathrm{~b}$ & 65 & 82 & 104 & 0.19 & 1.4 & 0.75 & $0.3-1.2$ & $0.2-0.7$ & 0.04 & 0.04 & $\begin{array}{l}+\mathrm{Mo}, \mathrm{Ni}, \mathrm{Nb}, \mathrm{Ti} \\
\text { Va and or } \mathrm{Zr}\end{array}$ \\
\hline \multirow{2}{*}{$\begin{array}{l}\text { JIS G3101-73 Rolled } \\
\text { Steel for General } \\
\text { Structure }\end{array}$} & SS55 & 57 & 78 & & 0.30 & 1.6 & & & & 0.04 & 0.04 & $\begin{array}{l}\text { Add any element } \\
\text { "if necessary" }\end{array}$ \\
\hline & SS50 & 40 & 71 & 88 & & & & & & 0.05 & 0.05 & \\
\hline
\end{tabular}

Key: C, carbon; Cr, chromium; Cu, copper; $F_{y}$, yield strength; JIS, Japan Industrial Standard; Mo, molybdenum; Nb, niobium; $\mathrm{Ni}$, nickel; P, phosphorus; Si, silicon; S, sulfur; Ti, titanium; TS, tensile strength; V, vanadium; $\mathrm{Zr}$, zirconium.

Note: Compositions are given as mass fractions. Thickness range for all standards is $16 \mathrm{~mm}<t<40 \mathrm{~mm}$.

Source: Intcrnational Technical Information Institute, Handbook of Comparative World Steel Standards (1974).

\section{$3.3 \quad$ STEELS USED IN CONSTRUCTION}

Information from the suppliers and fabricators was used to identify the specific steels supplied to meet those contractual requirements. Table 3-5 and Appendix A provide background information on the various fabricators of WTC steel, including tons of steel reported in their contracts. The rest of this section summarizes information on the steels used in the impact and fire zones of the towers. 
Table 3-5. Steel companies involved in WTC construction and their contracts.

\begin{tabular}{|l|l|l|c|}
\hline \multicolumn{1}{|c|}{ Fabricator } & \multicolumn{1}{|c|}{ Current Status } & \multicolumn{1}{c|}{ Component } & Tons \\
\hline Pacific Car and Foundry Co. & Sold in 1974 & Exterior columns and spandrels & 55,800 \\
\hline Montague Betts Co., Inc & $\begin{array}{l}\text { No longer a steel } \\
\text { fabricator }\end{array}$ & $\begin{array}{l}\text { Rolled columns and beams above 9th } \\
\text { floor }\end{array}$ & 25,900 \\
\hline Pittsburgh-Des Moines Steel Co. & & $\begin{array}{l}\text { Bifurcation columns ("trees") 4th to } \\
\text { 9th floor }\end{array}$ & 6,800 \\
\hline Atlas Machine \& Iron Works & No longer in business & $\begin{array}{l}\text { Box columns below the bifurcation } \\
\text { columns to 4th floor }\end{array}$ & 13,600 \\
\hline Mosher Steel Co. & Currently active & Core box columns below the 9th floor & 13,000 \\
\hline Stanray Pacific Corp. & Closed in 1971 & Core box columns above the 9th floor & 31,100 \\
\hline Levinson Steel Co. & $\begin{array}{l}\text { Sold in 1997, parent } \\
\text { company in bankruptcy }\end{array}$ & Supports for slabs below grade & 12,000 \\
\hline Laclede Steel Co. & $\begin{array}{l}\text { Bankrupt in 2001, new } \\
\text { owners of rolling mill }\end{array}$ & Floor trusses & Unknown \\
\hline Drier Structural Steel Co.. Inc. & Unknown & Grillages & Unknown \\
\hline & & Total & 141,170 \\
\hline
\end{tabular}

Source: Feld 1971.

\subsubsection{Floor Trusses}

Laclede Steel manufactured the trusses for the composite floor panels for both WTC 1 and WTC 2 from steel they made and rolled at their mill in Alton, Illinois. The chords were fabricated from hot-rolled angles, while the web was fabricated from hot-rolled round bar (Fig. 2-8).

According to internal Laclede documents (Bay $1968 \dagger$ ), the top chord angles, as well as most round bars, were fabricated to meet ASTM A $242\left(F_{y}=50 \mathrm{ksi}\right)$. Only $1.09 \mathrm{in} .(27.7 \mathrm{~mm})$ and $113 / 16 \mathrm{in} .(46.0 \mathrm{~mm})$ round bars and the bottom chord angles were specified as ASTM A 36. Conversations with Laclede metallurgists (Brown $2002+$ ) active during the WTC construction revealed that even for components specified as ASTM A 36, Laclede would have supplied a vanadium, micro-alloycd steel with a typical $F_{y}=50 \mathrm{ksi}$, similar to a contemporary A 572 steel. In all the Laclede documents NIST examined, there were only two different mill test reports on A 242 steel, both from mid-1969; see Table 3-6. Thcse mill reports indicate that the A 242 steel supplied is a niobium-containing steel similar to modern ASTM A 572 steels with yield points that exceed the specified minimum by about $10 \mathrm{ksi}$.

Table 3-6. Properties of Laclede ASTM A 242 steels obtained from Laclede mill reports.

\begin{tabular}{|c|c|c|c|c|c|c|c|c|}
\hline \multirow[b]{2}{*}{ Component } & \multirow{2}{*}{$\begin{array}{c}F_{y} \\
(\mathrm{ksi})\end{array}$} & \multicolumn{6}{|c|}{ Element Composition (mass \%) } & \multirow[b]{2}{*}{ Source } \\
\hline & & $\mathrm{C}$ & $M n$ & $\mathbf{P}$ & $\mathbf{S}$ & V & $\mathrm{Nb}$ & \\
\hline $\begin{array}{l}2 \text { in. by } 1.5 \text { in. by } 0.25 \text { in. bulb } \\
\text { angle heat } 83033\end{array}$ & 62.8 & 0.20 & 0.86 & 0.014 & 0.044 & NR & 0.020 & Kamper $1968 \dagger$ \\
\hline $\begin{array}{l}3 \text { in. by } 2 \text { in. by } 0.25 \text { in. bulb } \\
\text { angle heat } 83162\end{array}$ & 60.1 & 0.19 & 0.77 & 0.013 & 0.043 & NR & 0.015 & Kamper $1968 \dagger$ \\
\hline 1.14 in. rod heat 76056 & 54 & 0.19 & 0.80 & 0.005 & 0.024 & NR & NR & $\begin{array}{l}\text { White } 1969 \mathrm{~b} \dagger \\
2 \text { tests }\end{array}$ \\
\hline
\end{tabular}

Key: C, carbon; Mn. manganese; Nb, niobium; NR, not reported; P, phosphorous; S, sulfur; V, vanadium. 


\subsubsection{Perimeter Columns and Spandrels}

The perimeter wall columns, fabricated by PC\&F, were composed of three important subassemblies: the columns, the spandrels, and the truss seats. The structural plans called for the columns to be fabricated from 14 grades of steel with $F_{y}=(36,42,45,46,50,55,60,65,70,75,80,85,90$, and 100) ksi. Above the 75 th floor, more than half of the columns had yield strengths greater than or equal to $55 \mathrm{ksi}$ and less than or equal to $70 \mathrm{ksi}$. The spandrels were fabricated from 12 grades of steel with $F_{y}=(36,42,45,46$, $50,55,60,65,70,75,80$, and 85$) \mathrm{ksi}$. The truss seats were specified to be fabricated from steel with $F_{y}=36 \mathrm{ksi}$ minimum.

Yawata Iron and Steel Co. supplied most of the steel to PC\&F for the perimeter columns and spandrels. In general, the exterior (or web) and side (or flange) plates of each column and the spandrels were fabricated from Japanese steel, and the interior web plate (plate 3, Fig. 2-3) was fabricated from domestic steel (Symes 1969a §. White 1969a §). Searches of archival material yielded no information on the steels for the truss seats beyond the fact that they were specified as $F_{y}=36 \mathrm{ksi}$.

A contemporaneous Yawata document (Yawata $1969 \dagger$ ) indicates that Yawata shipped 46,000 metric tons of WEL-TEN 60, 60R, 62, 70, and 80 to PC\&F. That document refers to WEL-TEN 80, rather than WEL-TEN $80 \mathrm{C}$, which is a Yawata steel with a different chemistry, but identical yield strength. The document certainly refers to WEL-TEN 80C, because all other sources, including other Yawata sources, that mention WEL-TEN steels refer to WEL-TEN 80C. Most sources, for instance, Feld (1971a), put the PC\&F contract at 55,800 tons. Assuming the Yawata document (1969 †) refers to metric tons, that would still leave a minimum of 5,100 tons from other sources. The interior web plate (plate 3 ) represents about 12 percent of the total area of a perimeter column panel. The 5,100 tons unaccounted for in the Yawata contract is not inconsistent with the assertion that the interior web was usually fabricated from domestic steel, while the remaining plates were fabricated from Yawata steel.

Several sources (ENR 1967; Monti 1967a §; White 1967a §; Feld 1967a §) indicate that Kawasaki Steel also supplied PC\&F, but apparently only $36 \mathrm{ksi}$ grade (Feld 1967a §). Ronald Symes (2002 †), PC\&F chief engineer, could not remember any other foreign steel suppliers other than Kawasaki. However, the fabricators only interacted with the Japanese import companies rather than with the steel mills directly. Mitsui (now Mitsui USA) imported the Japanese steel for PC\&F. Because the side plates and spandrels are the primary structural components of the perimeter columns, and they were all fabricated from Yawata steel, the properties of the perimeter columns can be based on the mechanical properties of the Yawata steels.

During the 1960s, Yawata produced a number of named, proprietary grades (such as WEL-TEN and YAW-TEN series) of weldable steels with specified minimum properties. Several of these named grades supplied to PC\&F (WEL-TEN 60, WEL-TEN 62, WEL-TEN 80C) are common in the contemporaneous literature, and open literature publications (Ito 1965a, 1965b; Goda 1964) describe many of their physical and mechanical properties other than specified minimum strength quite extensively. For two of the named, proprietary grades that Yawata supplied to PC\&F (WEL-TEN 60R and WEL-TEN 70), NIST has been unable to find corroborating specifications or mechanical property data, even in consultation with Nippon Steel. It is possible that these names were assigned simply for convenience for the WTC construction. Chemically, WEL-TEN 60,60R, and 62 are similar to contemporary ASTM A 588, with their $\mathrm{Cr}$ additions and high silicon contents, though none would meet that specification exactly. WEL-TEN 60, 62, and 70 are heat-treated steels, while WEL-TEN 60R is a hot-rolled steel. 
WEL-TEN 80C is a Cr-Mo steel that is very similar to contemporary A 514 steels, and possibly could have been manufactured to meet that contemporary specification. According to PC\&F documents (Symes $1967 \mathrm{c}$ \$). Yawata intended to supply grades that would meet the "ASTM A 441-modified" specification (see Table 3-2) of PONYA for the lower strength column plates. From the proposed specification, these "A 441-modified" compositions were similar to contemporary A 588 steels, with their added Cr and use of $\mathrm{Nb}$ for strengthening. Their chemistries do not correspond to any other named grade of Yawata steel, for example WEL-TEN 50. WEL-TEN 55, YES 36, YES 40, or YAW-TEN 50. For the intermediate strength plates ( $55 \mathrm{ksi}, 60 \mathrm{ksi}$, and $65 \mathrm{ksi}$ ), Yawata intended to furnish heat-treated WEL-TEN grades for the thicker sections and the hot-rolled "A 441 modified" grades for the thinner sections. Tables 3-7 and 3-8 summarize these specifications and representative properties, obtained from a variety of documents. Note that not all the sources agree on yield strength or chemistries, probably because Yawata could tailor the steels for specific applications. The entries at the top of the tables are for the steels that a PC\&F memo (Symes 1967c §) mentions, while the bottom entries detail representative data culled from many literature sources for all grades of Yawata weldable steels.

NIST has located a total of six mill reports (tests performed at the Yawata rolling mill) describing 135 plates (Symes 1969b $\S$; Barkshire 1969a $\S$; White 1969c $\S$ ) of Yawata steels: two for $F_{y}=75 \mathrm{ksi}$, one for $F_{y}=70 \mathrm{ksi}$, two for $F_{y}=50 \mathrm{ksi}$, and one for $F_{y}=45 \mathrm{ksi}$. When the originals were microfilmed after the construction was completed. the technician did not rotate the landscape pages into portrait orientation, so the sheets only show the measured yield point, tensile strength, and elongation, but not chemistry. For each steel, the measured yield strength of the plates increases with decreasing thickness. The thickest WEL-TEN 62 plates $(t=1.5 \mathrm{in}$.) typically have yield strengths $5 \mathrm{ksi}$ greater than the specified yield strength. The thinnest plates ( $t=0.375 \mathrm{in}$.) have yield strengths $15 \mathrm{ksi}$ to $20 \mathrm{ksi}$ greater than the stated yield strength. For the lower strength plates $\left(F_{y}=45 \mathrm{ksi}\right.$ and $\left.F_{y}=50 \mathrm{ksi}\right)$, the measured yield strength increases less rapidly with decreasing thickness: to a first approximation, their strength is independent of thickness. They average $7.4 \mathrm{ksi}$ and $11.8 \mathrm{ksi}$ greater than the specified yield strength, respectively.

Contemporaneous documents indicate that PC\&F also purchased V-series (White 1968a $\S, 2003 \dagger$ ) and modified V-series plate from Bethlehem Steel (Symes 1967a §), EX-TEN and modified EX-TEN from U.S. Steel (Symes 1967a §; White $2003 \uparrow$; Barkshire 1968a §), and various Kaisaloy grades (Barkshire $1968 \mathrm{~b} \S$ ) from Kaiser steel, for use in the intcrior plates. The interior plate (plate 3, Fig. 2-3) is usually half the thickness of the side plates, and never exceeds $15 / 16$ in. thick, and so represents at most 5 percent of the mass of steel in the entire contract. Status reports from mid-1968 indicate that PC\&F phased out U.S. Steel and Kaiser and replaced them with Bethlehem as the only domestic supplier (Barkshire 1968c §). Presumably, most of the inner web plates (plate 3, Fig. 2-3) in the columns near the impact floors were made from hot-rolled Bcthlehem V-series steels. Table 3-9 summarizes the properties of the V-series (Alloy Digest 1970) and modified V-series steels (Symes 1967b §).

In summary, NIST has extensive data from open literature sources for properties other than chemistry and yield strength for the $65 \mathrm{ksi}$ WEL-TEN 60, the $70 \mathrm{ksi}$ WEL-TEN 62, and the $100 \mathrm{ksi}$ WEL-TEN 80C. Properties for the "A 441-modified" grades and for WEL-TEN 70 and WEL-TEN 60R must be estimated theoretically or experimentally. 


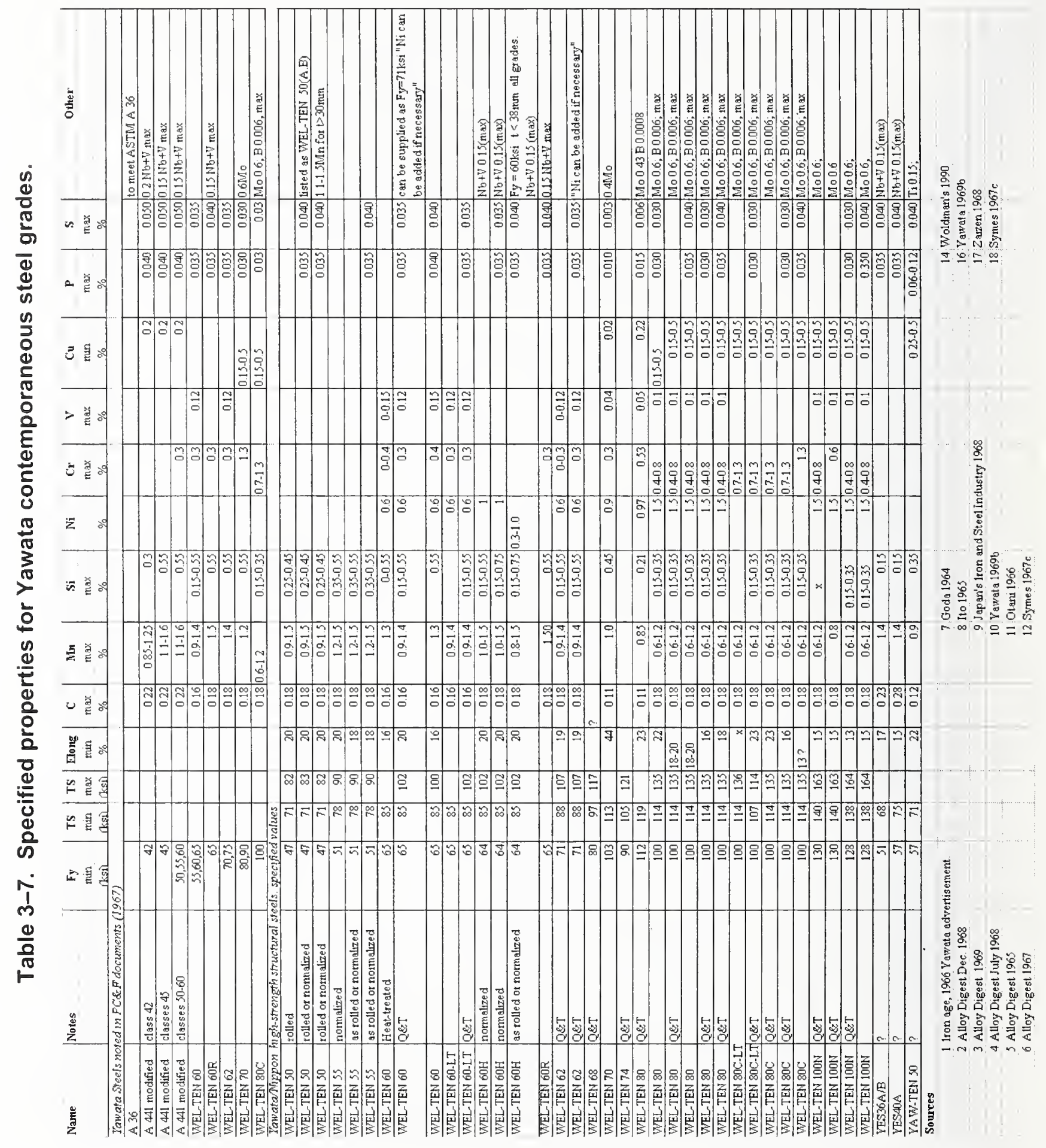




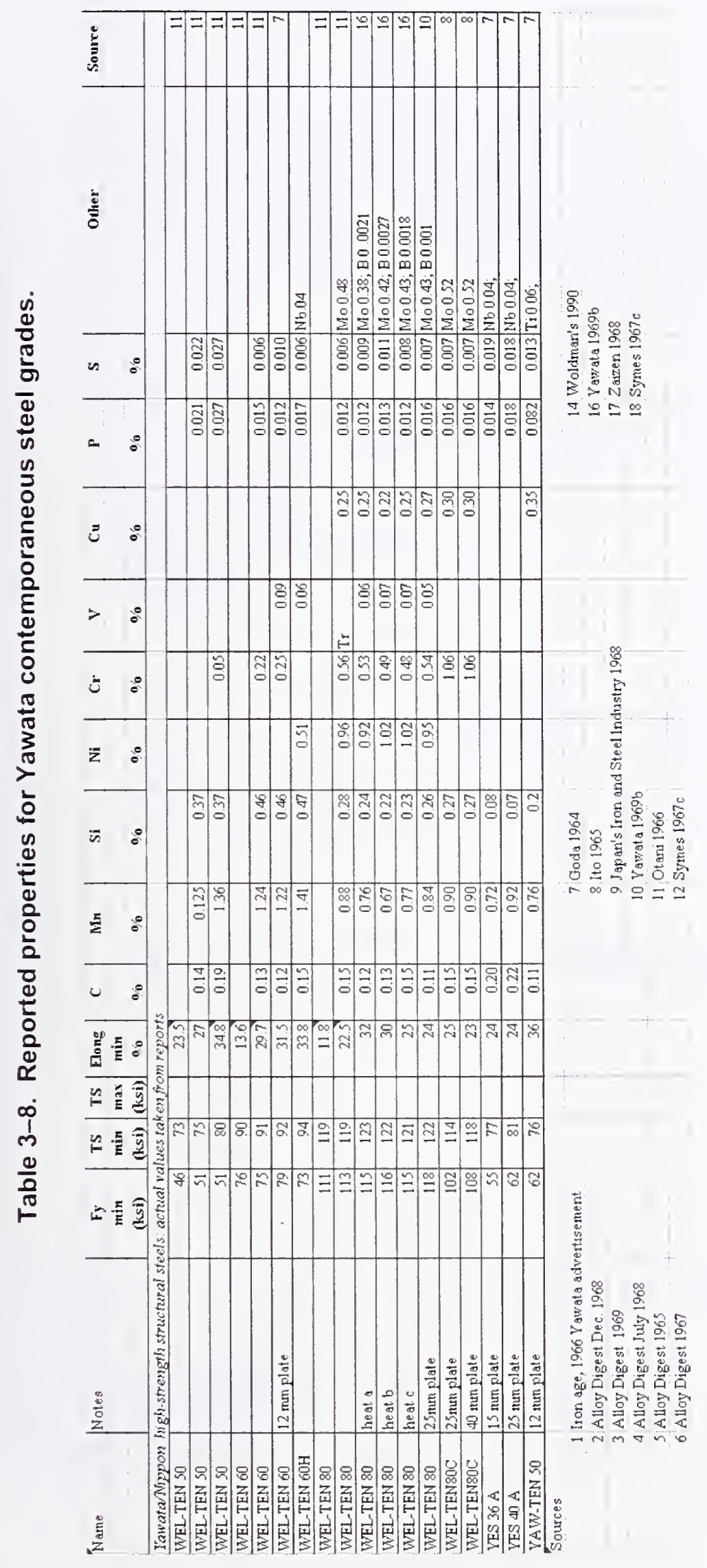




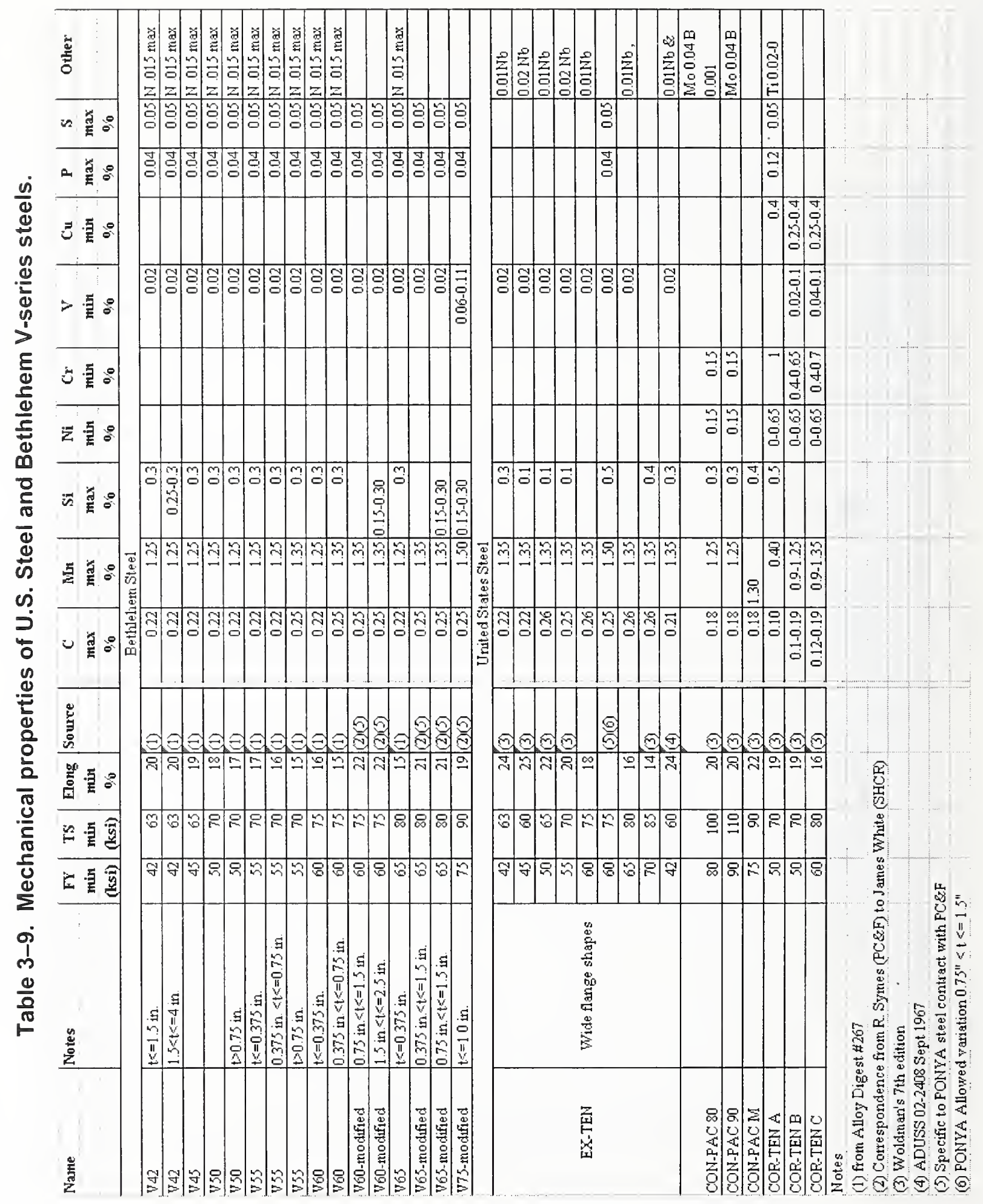




\subsubsection{Core (Welded Box Columns)}

Stanray Pacific Corp. fabricated the welded core columns in both buildings above the 9th floor. The plans called for two grades of steel with $36 \mathrm{ksi}$ and $42 \mathrm{ksi}$ minimum yield strengths. Contemporancous documents (Morris 1967 §; Warner 1967 ) indicate that Stanray Pacific purchased at least 10,240 tons (of an estimated 32,000 tons) of plate from Colvilles Ltd. (rolled in the Dalzell Works, Motherwell, Scotland). Telephone conversations with M. McKnight (McKnight $2003 \dagger$ ), formcrly with the British Steel Export Association, which imported the steel to the United States, confirmed Colvilles as a supplier to Stanray Pacific. The rest of the plate (21,760 tons) came from Fuji Iron and Steel, Hirohata Works (Morris 1967 §; Warner 1967 §). A report (Yamada 1967) of the first shipment of plates from Japan lists the plates as being A 36 and A 572 grade 42. This is not a mill report, however, so it not completcly certain that the higher strength plates were supplied to A 572, which was not listed in the Port Authority contract. Later records (Tarkan 1969 §) include a mill sheet for a plate purchased from Nippon Kokan Steel of Fukuyama, Japan. Because the sum of the Colvilles and Fuji contracts (32,000 tons) that Warner reported (1967 §) is larger than the PONYA value (Feld 1971a) of the contract (31,100 tons), this was probably an isolated, uncommon substitution. NIST has located a mill report for a single Fuji Steel A 36 plate (Morris 1969 §), and a third-party chemical analysis of a Colvilles plate (Walton 1968 )

(Table 3-10). Other than these, NIST has located no other mill records. See Table 3-11 for the search details.

Table 3-10. Chemistry and mechanical property data for a Fuji Steel plate and a Colvilles plate used for core columns.

\begin{tabular}{|c|c|c|c|c|c|c|c|c|c|c|c|c|c|c|}
\hline Description & $\begin{array}{c}F_{y} \\
\text { (ksi) }\end{array}$ & $\begin{array}{c}T S \\
\text { (ksi) }\end{array}$ & $\begin{array}{c}E l_{t} \\
(\%)\end{array}$ & \multicolumn{9}{|c|}{ Element Composition (mass \%) } & Other & Source \\
\hline $\begin{array}{l}12.6 \text { ton A } 36 \text { plate } \\
3 \text { in. by } 65.5 \text { in. by } \\
453.75 \text { in. Rolled at } \\
\text { Hirohata works. Fuji } \\
\text { Steel; tested } \\
\text { August } 5,1969 .\end{array}$ & 38.4 & 64.9 & 32 & 0.2 & 0.96 & 0.2 & ND & ND & ND & ND & 0.013 & 0.008 & & (a) \\
\hline $\begin{array}{l}\text { Chemical analysis of } \\
\text { a } 6 \text { in. by } 52 \mathrm{in.} \mathrm{by} \\
18 \mathrm{ft} 0.75 \text { in. } \\
\text { Colvilles A } 36 \text { plate } \\
\text { Heat } \mathrm{H} 218 \\
\text { Slab } 1804 \mathrm{H} \text { by } \\
\text { Materials Testing } \\
\text { Laboratory, Los } \\
\text { Angeles, CA, } \\
\text { February 2.1968. }\end{array}$ & ND & ND & ND & 0.2 & 0.99 & 0.3 & 0.2 & $<0.01$ & 0.005 & 0.2 & 0.017 & 0.035 & $\begin{array}{c}0.01 \mathrm{Mo} \\
0.02 \mathrm{Co}\end{array}$ & (b) \\
\hline
\end{tabular}

a. Morris 1969.

b. Walton 1969.

Key: $\mathrm{C}$, carbon; $\mathrm{Cr}$, chromium; $\mathrm{Cu}$, copper; $E I_{t}$, elongation to failure; $F_{y}$, specified minimum yield strength; Mn, manganese;

ND, not determined; Ni, nickel; $\mathrm{P}$, phosphorus; $\mathrm{S}$, sulfur; Si, silicon; $T \dot{S}$, tensile strength; $\mathrm{V}$, vanadium.

A mid-1967 document (Warner 1967 §) indicates that Fuji Steel supplied all plates thinner than 1.75 in. Both Fuji and Colvilles supplied plates 1.75 in. and thicker, but even there, Fuji supplied about 60 percent of the total mass of steel used. In the fire and impact floors of WTC 1 (floor 94 to floor 98), only three of the columns are welded, box columns, and all three are made from plate thinner than $1.75 \mathrm{in}$. In the fire and impact floors of WTC 2 (floor 78 to floor 84), only 9 of 52 welded box columns are made from plate 
1.75 in. or thicker. In terms of steel properties for modeling, then, the columns can be modeled with the properties of the Fuji-supplied plates alone.

\subsubsection{Core (Rolled Wide-Flange Shapes)}

Montague-Betts Steel fabricated all the rolled, wide-flange (WF) shapes for the core columns, as well as all the beams in both towers above the 9 th floor. These rolled shapes represent a significant fraction of the total core columns in the fire and impact zone. Above the 80th floor in WTC 2, more than half of the core columns were WF shapes, and above the 94th floor in WTC 1, 43 of the 46 columns are WF shapes. The plans called for steels with $36 \mathrm{ksi}, 42 \mathrm{ksi}, 45 \mathrm{ksi}$, and $50 \mathrm{ksi}$ minimum yield strengths, but very few of the rolled shapes used the $45 \mathrm{ksi}$ or the $50 \mathrm{ksi}$ material. Various sources (Davis $2002 \uparrow$; Yawata $1969 \dagger$ ) confirm that Montague-Betts purchased about 12,000 tons (of a total contract of 25,900 tons) of A 36 and A 441 wide flange shapes from Yawata Iron and Steel, Sakai Works. An additional 1,200 tons came from Dorman-Long, Lackenby Works, Middlesborough, England (Gallagher 1968 §; Goode 1967 ). Given the size of the Yawata contract, it is likely that it represents the majority, if not all, of the WF core columns. Because Yawata engineers felt that the "A 441-modified" composition was protected by a U.S. Steel patent (Clarkson 1967 §), they also obtained permission to supply high-strength steel to different "A 441-modified" composition (see Table 3-3) with 0.2 percent to 0.4 percent mass fraction added $\mathrm{Ni}$ (White $1967 \mathrm{~b} \S$ ). Whether this approval represents a complete substitution of a Yawata specific altcrnate "A 441 modified" for the original A 441 modified, or simply an alternate specification for use in limited instances, is unknown. Montague-Betts chief executive officer, William Davis $(2002 \div)$, who worked on the project, confirmed that Montague-Betts also purchased steel from Bethlehem and U.S. Steel, the only two domestic mills that produced $14 \mathrm{WF}$ rolled sections heavier than $87 \mathrm{lb} / \mathrm{ft}$ (AISC 1973). To date, NIST has found no mill records for chemistry or mechanical properties for any of the steels used in the Montague-Betts contract. See Table 3-11 for the search details.

\subsection{SOURCES OF INFORMATION}

Preliminary searches used open literature sources of information, including trade journals, to locate information on the various companies and steels involved in construction. Table 3-12 lists the journals examined, and the strategy for locating WTC specific information. Table 3-13 lists similar information for the databases and search strategies used to locate WTC information.

After identifying the fabrication companies, NIST contacted Laclede Steel Corporation, Nippon (formerly Yawata) Steel, PACCAR (formerly Pacific Car and Foundry), Montague Betts, and Dovell Engineering, and several former employees of Stanray Pacific and Pacific Car and Foundry. NIST did not attempt to contact fabricators that were only involved in the lower floors (Atlas Machine and Iron Works, Levinson, Mosher, and Drier.) Table 3-11 summarizes these contacts and information. Most of the information in this report came from the archives of the PANYNJ. 
Table 3-11. Sources examined for mill reports and other construction information, other than the PANYNJ archives.

\begin{tabular}{|c|c|c|}
\hline Contact & Background & Result \\
\hline $\begin{array}{l}\text { Laclede Steel Corporation } \\
\text { David McGee } \\
\text { Larry Hutchison }\end{array}$ & $\begin{array}{l}\text { Laclede fabricated the trusses for the } \\
\text { floor panels. }\end{array}$ & $\begin{array}{l}\text { During Nov. } 2002 \text { NIST personnel visited } \\
\text { Laclede, which shared material from its } \\
\text { archive, including two mill test reports. }\end{array}$ \\
\hline $\begin{array}{l}\text { Ronald Symes Former Chief } \\
\text { Engineer, PC\&F }\end{array}$ & $\begin{array}{l}\text { PC\&F fabricated the perimeter } \\
\text { columns. }\end{array}$ & $\begin{array}{l}\text { Symes did not retain any WTC documents } \\
\text { relating to steel properties, but he did have } \\
\text { information on welding }\end{array}$ \\
\hline $\begin{array}{l}\text { Nicholas Soldano Former } \\
\text { general manager, PC\&F }\end{array}$ & - & $\begin{array}{l}\text { Soldano provided information on steel } \\
\text { substitutions, but had no WTC documents. }\end{array}$ \\
\hline $\begin{array}{l}\text { D. Bangert, VP for facilities } \\
\text { PACCAR }\end{array}$ & $\begin{array}{l}\text { PACCAR owned Pacific Car and } \\
\text { Foundry before selling it in } 1974 .\end{array}$ & $\begin{array}{l}\text { PACCAR retained no records relating to } \\
\text { any aspect of PC\&F }\end{array}$ \\
\hline $\begin{array}{l}\text { Nippon Steel USA } \\
\text { Tomokatsu Kobayashi, VP }\end{array}$ & $\begin{array}{l}\text { Nippon Steel formed by the merger } \\
\text { of Yawata and Fuji Steel, which } \\
\text { together supplied most of the } \\
\text { Japanese steel. }\end{array}$ & $\begin{array}{l}\text { Nippon located several 1960s era data } \\
\text { sheets for Yawata WEL-TEN steels, but } \\
\text { no mill test reports for steels used in the } \\
\text { WTC. }\end{array}$ \\
\hline Mitsui USA, Janet Garland & Mitsui imported the steel for PC\&F & Mitsui has no WTC records. \\
\hline $\begin{array}{l}\text { Carl Lojic, former president, } \\
\text { Joseph Tarkan, former Chief } \\
\text { Engineer, Stanray Pacific }\end{array}$ & $\begin{array}{l}\text { Stanray Corp closed its fabricating } \\
\text { business in } 1969, \text { and has apparently } \\
\text { gone out of business. }\end{array}$ & $\begin{array}{l}\text { Neither Lojic nor Tarkan retained any } \\
\text { documents from the project. }\end{array}$ \\
\hline $\begin{array}{l}\text { Corus Construction \& } \\
\text { Industrial Homi Sethna }\end{array}$ & $\begin{array}{l}\text { Corus (formerly British Steel) owns } \\
\text { the works that rolled the thicker } \\
\text { plate for the welded core columns. }\end{array}$ & $\begin{array}{l}\text { Corus was unable to locate any records } \\
\text { from the WTC era. }\end{array}$ \\
\hline $\begin{array}{l}\text { Tony Wall, President, Dovell } \\
\text { Engineering }\end{array}$ & $\begin{array}{l}\text { Dovell was the detailer for Stanray } \\
\text { Pacific. }\end{array}$ & $\begin{array}{l}\text { The Northridge earthquake damaged their } \\
\text { building. During clean-up they disposed } \\
\text { of all WTC documents. }\end{array}$ \\
\hline $\begin{array}{l}\text { William Betts, CEO } \\
\text { Montague-Betts }\end{array}$ & $\begin{array}{l}\text { Montague-Betts fabricated all rolled } \\
\text { shapes above the } 9 \text { th floor. }\end{array}$ & $\begin{array}{l}\text { Six years after completion, } \\
\text { Montague-Betts destroyed, as per } \\
\text { company policy, all records relating to the } \\
\text { WTC construction. }\end{array}$ \\
\hline $\begin{array}{l}\text { Marubeni-ltochu Steel } \\
\text { Tadashi Yaegashi Chief } \\
\text { Administrative Officer }\end{array}$ & $\begin{array}{l}\text { Marubeni-Itochu succeeded } \\
\text { Marubeni-Iida, which imported the } \\
\text { Yawata steel for Montague-Betts. }\end{array}$ & $\begin{array}{l}\text { "All sales transactions going back to the } \\
1960 \text { 's have been destroyed" }\end{array}$ \\
\hline $\begin{array}{l}\text { SGS US Testing Company } \\
\text { Rich Franconeri }\end{array}$ & $\begin{array}{l}\text { SGS succeeded US Testing and The } \\
\text { Superintendence Co., both of which } \\
\text { inspected the Japanese steel. }\end{array}$ & $\begin{array}{l}\text { SGS was unable to locate any documents } \\
\text { from that era. }\end{array}$ \\
\hline $\begin{array}{l}\text { Skilling, Ward, Magnussen, } \\
\text { and Barkshire (SWMB); Jon } \\
\text { Magnussen, partner }\end{array}$ & $\begin{array}{l}\text { SWMB is the successor to the } \\
\text { structural engineering firm that } \\
\text { designed the towers. }\end{array}$ & $\begin{array}{l}\text { SWMB retained no WTC records. They } \\
\text { transferred everything to LERA. NIST } \\
\text { has access to these records. }\end{array}$ \\
\hline $\begin{array}{l}\text { Tishman Realty and } \\
\text { Construction; Linda } \\
\text { Christensen }\end{array}$ & $\begin{array}{l}\text { Tishman was the general contractor } \\
\text { for the construction. }\end{array}$ & $\begin{array}{l}\text { "[O]ur archive facility has standing orders } \\
\text { that any and all files over seven years in } \\
\text { age are to be destroyed." }\end{array}$ \\
\hline
\end{tabular}


Table 3-12. Trade journals examined for WTC steel information.

\begin{tabular}{|l|l|}
\hline \multicolumn{1}{|c|}{ Journal } & \multicolumn{1}{|c|}{ Search Method } \\
\hline Acier Stahl Steel & 1966 to 1972 Tables of Contents. \\
\hline Civil Engineer-ASCE & 1965 to 1973 lndex on WTC. \\
\hline $\begin{array}{l}\text { Engineering News Record } \\
\text { Also, see compilation volume of all articles published (ENR 1972) }\end{array}$ & $\begin{array}{l}1967 \text { to } 1973 \text { Index on WTC, New York } \\
\text { City. }\end{array}$ \\
\hline The Iron Age & $\begin{array}{l}1966 \text { to } 1968 \text { Index on Japan, WTC, } \\
\text { structural steel, fabricator and steel company } \\
\text { name. }\end{array}$ \\
\hline Iron and Steel & Page-by-page for 1968 to 1971. \\
\hline Iron and Steel Engineer & $\begin{array}{l}1967 \text { to June 1968 Table of Contents, } \\
\text { Dateline column, lndustry news column. } \\
\text { Index is not topical. }\end{array}$ \\
\hline Japan's lron and Steel Industry 1967-1970 & 1967 to 1970 page-by-page. \\
\hline Metal Construction & Page-by-page. \\
\hline Metal Progress & Page-by-page. \\
\hline Modern Steel Construction & Tables of Contents. \\
\hline Nihon Kinzoku Gakkaishi (J. Jap. Inst. Metals) & Cursory, WTC era. \\
\hline Steel & $\begin{array}{l}1966 \text { to 1969 Index on Japan, WTC, } \\
\text { fabricator and steel company name. }\end{array}$ \\
\hline Transactions of the Iron and Steel Institute of Japan & $\begin{array}{l}1965 \text { to 1969 Table of Contents and news } \\
\text { pages. }\end{array}$ \\
\hline Stahlbau & 1966 to 1973 Index under Hochbau. \\
\hline Steelways & - \\
\hline Structural Engineer & 1966 to 1972 cursory. \\
\hline Welding Design and Fabrication & Cursory. \\
\hline West of Scotland Iron and Steel Institute Journal & 1966 to 1969 Tables of Contents. \\
\hline
\end{tabular}

Table 3-13. Databases searched for WTC information.

\begin{tabular}{|l|l|l|}
\hline \multicolumn{1}{|c|}{ Database } & \multicolumn{1}{|c|}{ Query } & \multicolumn{1}{c|}{ Earliest year covered } \\
\hline $\begin{array}{l}\text { Cambridge Scientific Databases: } \\
\text { Metadex, Weldasearch }\end{array}$ & $\begin{array}{l}\text { Yawata } \\
\text { WTC }\end{array}$ & $\begin{array}{l}1966 \text { (Metadex) } \\
1967 \text { (Weldasearch) }\end{array}$ \\
\hline $\begin{array}{l}\text { OCLC FirstSearch } \\
\text { Database: WorldCat }\end{array}$ & $\begin{array}{l}\text { Search for steel periodicals - used to identify } \\
\text { possible additional sources of information } \\
\text { Search for library holdings of } \\
\text { contemporaneous steel catalogs. Also } \\
\text { searched on Alibris for used steel data sheets. }\end{array}$ & 19th century \\
\hline $\begin{array}{l}\text { American Society of Civil } \\
\text { Engineers Database } \\
\text { www.pubs.asce.org }\end{array}$ & $\begin{array}{l}\text { WTC, Yawata, Stanray, Pacific Car and } \\
\text { Foundry: no useful information }\end{array}$ & 1973 \\
\hline
\end{tabular}


Initially, NIST had hoped to find the mill test reports for the steel used, which would have provided complete yield $\left(F_{y}\right)$ and tensile strength and chemistry information for all the steels. Each fabricating company, as part of the quality control program required by their contract with the Port Authority, supplied this information to Tishman, the general contractor, to Skilling, Helle, Christiansen, \& Robertson (SHCR), the structural engineers, and to the Port Authority. Unfortunately, Laclede, Montague-Betts (Davis $2003 \dagger$ ), PACCAR (Bangert $2002 \dagger$ ) (the new name of Pacific Car and Foundry), SHCR (Magnussen $2002 \dagger$ ), and Tishman (Christensen $2003 \dagger$ ) all confirm that they have no mill reports from that era.

NIST also contacted several of the inspection companies (Franconeri $2003 \dagger$ ) and the steel

(Sethna $2003 \dagger$ ) and steel importing companies(Garland $2004 \dagger$; Yaegashi 2003†) (Table 3-11) as well as Crest Steel, which some Stanray Pacific communications mention (Steinberg $2002 \dagger$ ). All confirmed that they retained no records relating to steel for the WTC.

NIST located six pages of mill reports for PC\&F in the PANYNJ archives, and several individual mill reports in the Laclede archives. 
This page intentionally left blank. 


\section{Chapter 4 \\ CONTEMPORANEOUS CONSTRUCTION SPECIFICATIONS}

\subsection{INTRODUCTION}

Chapter 3, "Contemporaneous Steel Specifications" traces the sources and grades of steel used to fabricate structural steel components for the World Trade Center (WTC) towers. This chapter supplements that information by extending further into the construction process, specifically adding information on the fabrication (welding) of components and the erection of the buildings.

\subsection{FABRICATION OF THE VARIOUS COMPONENTS}

\subsubsection{Floor Trusses}

Laclede Steel manufactured the trusses for the floor panels for both WTC 1 and WTC 2 from steel they made at their mill in Alton, 1llinois. The chords of the trusses were fabricated from hot-rolled angles, while the web was from hot-rolled round bar. The web and the chord angles were joined by resistance welding (Laclede 1969).

Little information is available on the standards used for fabrication of the floor trusses. However, floor joist standards existed since 1929. The American Institute of Stecl Construction (AISC) Manual (1972) Standard Specifications for Open Web Steel Joists specifies that $36 \mathrm{ksi}$ and $50 \mathrm{ksi}$ minimum yield strength steel are permitted in such bar joists, and that "Joint connections and splices shall be made by attaching the members to one another by arc or resistance welding or other approved methods." A Technical Digest from the Steel Joist Institute (Somers 1980) also confirms the use of resistance welding.

\subsubsection{Exterior Wall Columns and Spandrels}

The perimeter column panels, fabricated by Pacific Car and Foundry (PC\&F), are composcd of three important subassemblies: the columns, the spandrels, and the seats. A Welding Design and Fabrication article (1970a) describes the fabrication sequence, which began with forming the inside wall of the modules (using a butt joint to link the spandrel plates to the inner column webs), followed by the addition of the sides and outer face of the columns by six simultaneous submerged arc welds. PC\&F constructed a 16-station automated production line to keep up with the schedule of 55,800 tons of perimeter column panels between November 1967 and August 1970, an average of 1,400 tons per month.

The construction contract states that the submerged arc electrodes used in the WTC were purchased to the requirements of ASTM Standard A 558 "Specification for Bare Mild Steel Electrodes and Fluxes for Submerged Arc Welding." This standard was withdrawn in 1969 and was replaced by an equivalent American Welding Society (AWS) Standard A 5.17 "Bare Mild Steel Electrodes and Fluxes for Submerged Arc Welding." The period 1965 to 1969 was one of transition, during which AWS assumed the responsibility of maintaining the standards for welding filler materials. Because the contract was awarded in 1967, the fabrication was likely started with the requirements of the 1965 version of the 
ASTM Standard (ASTM A 558-65T, jointly published by AWS as AWS A 5.17-65T), but latcr perimeter column panels may have included some minor changes associated with the conversion to the 1969 version of the AWS Standard (AWS A 5.17-69). Distorted columns were straightened in the conventional manner by heating just after column assembly, so any low-strength areas in the steel plates and changes in microstructure should not be interpreted solely in terms of the airplane impact and subscquent fires.

The Welding Design and Fabrication article (1970b) further states that PC\&F inspected the perimeter column panel welds using either ultrasonic, or visual and magnetic particle techniques.

The inner wall assembly (the spandrels and inner plates of the perimeter column panels) was joined with full penetration welds according to the requirements of AWS D 2.0 "Specifications for Welded Highway and Railway Bridges." This probably refers to the 1966 version of AWS D 2.0. They may have chosen this standard over D 1.0 "Code for Welding in Building Construction" because, at the time, D 1.0 was limited to steel strengths under $60 \mathrm{ksi}$ (Fenton 1966). AWS D 2.0 specifies various dimension and strength requirements for the assemblics and their welds (e.g., paragraph 302 and 403). This standard, like most standards, lags the steel technology of the time. Thus, it seems to be mostly designed around the application of fairly old steels. like A 7, A 36, and A 373. However, newer steels, such as the higher strength steels used in the WTC towers, could be used after formal approval.

Once the inner wall was ready, the columns were assembled from side plates, butt plates, diaphragm plates, and flange plates (Welding Design 1970a). Once assembled and preheated, the plates were joined in the main fillet weld gantry, a station that made six, 0.75 in $(19 \mathrm{~mm})$ filiet welds simultaneously along the length of the perimeter column panel. Then the module was jacked 90 degrees, and the other six fillet welds were made along the length of the panel. At full production, this gantry laid down $2,900 \mathrm{lb}$ $(1,300 \mathrm{~kg})$ of weld metal a day. These large fillet welds started $6 \mathrm{in}$. $(150 \mathrm{~mm})$ from the ends of the columns, so manual welding was used to finish the welding of the ends and to make any repairs.

\subsubsection{Core (Welded Box Columns)}

Stanray Pacific Corp. fabricated the welded core columns in both buildings above the 9th floor. Like PC\&F, they used large assembly fixtures and triple submerged arc welding stations to achieve high production rates. Review of some of the correspondence generated during the initial stages of the fabrication shows the level of attention to welding and inspection details needed to meet the requirements of Port of New York Authority (PONYA or Port Authority) and Skilling, Helle, Christiansen, \& Robertson (SHCR) as described below.

A September 1967 draft of the contract between PONYA and The United States Testing Laboratory (a third-party inspector) lists the documentation that would be required of the work at Stanray Pacific Corp. (White 1967c $\S$ ). This contract prescribes daily and weekly written reports of components that are accepted, those that are rejected, and a summary of any problems, with copies going both to the construction manager and to SHCR. In addition, a weekly report was sent with all the chemical and physical (mechanical) tests performed. The inspectors checked the various steps from plate delivery (checking heat number, specification conformance, and condition), through fabrication (alignment, 100 percent visual inspection of the welds, and selection of regions for nondestructive testing), to final inspection (perpendicularity of milled ends, overall length, cleaning, and marking). PONYA also had a procedure to inspect the steel from all sources. The procedure included double-checking the mill 
certificates by performing a tensile test and a check analysis on 1 out of 10 heats selected at random (Monti $1967 \mathrm{~b} \S$ ). The requirements were still higher for steel with strengths above $50 \mathrm{ksi}$ or from foreign sources. The welding procedures, welders, and welding operators werc qualified in accordancc with requirements of Appendix D of AWS Codes D1.1-66 and D 2.0-66. The welding electrodes for manual metal are welding conformed to ASTM A 233-64T, E60 and E70 series (also AWS A 5.1-64T). Mild steel electrodes and fluxes for submerged are welding conformed to ASTM A 588-65T (also AWS A 5.17-65T) and to Sec. 1.17.3 of the AISC Specification for Structural Steel Buildings.

By October 1967, welders were being qualified, magnetic particle inspector qualification was being discussed (based on a minimum of 40 hours of training), and chemical analysis of the steel was underway (Chauner 1967a). The level of inspector oversight continued to increase until by November 10 "U.S. Testing inspectors are all over the place and recording a lot of information" (Chauner 1967b). The level of attention to detail increased even more after a surprise visit to Stanray by Hugh Gallagher, a PONYA inspector, on November 20, 1967 (Gallagher 1967).

From reading the correspondence, it is apparent that toward the beginning of the contracts, the various fabricators faced major (and perhaps unexpected) challenges introduced by both the tight production schedule and PONYA and SHCR's strict quality requirements.

\subsubsection{Connections (Bolts and Welds)}

The Port Authority contract allowed the use of ASTM A 307, A 325, and A 490 fasteners. The WTC Design Standards book (p. DS 1-6) calls for the use of ASTM A 325 bolts with no indication of type. According to the standard, they would have therefore been supplied as Type 1. As in the contemporary version of ASTM A 325, Type 1 bolts in 1970 had $F_{y^{\prime}}=120 \mathrm{ksi}$ for diameters up to and including 1 in. and $F_{y}=105 \mathrm{ksi}$ for larger diameters. ASTM A 325-70 docs differ significantly from ASTM A 325-02 in several ways. In particular, the specification for Type 2 bolts was withdrawn in 1991. ASTM A 325-02 also admits three new chemistries for Type 1 bolts. In ASTM A 325-02, the specification for Type 1 Carbon Steel bolts most closely approximates the Type 1 bolts of A 325-70. Table 4-1 compares the chemistry requirements of the two standards. A 325-70 also admits a slightly wider range of acceptable hardness, which is currently in Table 3 of A 325-02.

Spandrels of adjacent perimeter column panels were attached together with high-strength bolted shear connections. Adjacent spandrels were butted to each other with splice plates on the inside and outside (Fig. 2-3). For floors 9 to 107 , each spandrel was connected to the splice plates with anywhere from 6 bolts to 32 bolts, depending on design load. Splice plates werc all $36 \mathrm{ksi}$ steel regardless of spandrel grade. Bolts for all connections between spandrels conformed to ASTM A 325. Minutes of a May 1967 (Feld 1967a) meeting between PC\&F, PONYA, and Koch, state that no A 490 bolts were to be used for the spandrel splice plates, and that only A 325 bolts were to be used there. "Bow-tie" spandrels in trees below floor 9 were connected with heavy $42 \mathrm{ksi}$ splice plates with A 325 or A 490 bolts in friction connections. 


\section{Table 4-1. Comparison of chemistry requirements for ASTM A 325 "Standard Specification for High-Strength Bolts for Structural Steel Joints, including Suitable Nuts and Plain Hardened Washers" between 1970 and 2002 standards.}

\begin{tabular}{|c|c|c|}
\hline Element & $\begin{array}{c}\text { ASTM A 325-70 } \\
\text { (\% mass fraction) } \\
\text { Maximum }\end{array}$ & $\begin{array}{c}\text { ASTM A 325-02 } \\
\text { (\% mass fraction) } \\
\text { Maximum }\end{array}$ \\
\hline $\mathrm{C}$ & 0.27 & $0.28-0.55$ \\
\hline $\mathrm{Mn}$ & 0.47 & 0.57 \\
\hline $\mathrm{P}$ & 0.048 & 0.048 \\
\hline $\mathrm{S}$ & 0.058 & 0.058 \\
\hline $\mathrm{Si}$ & - & $0.13-0.32$ \\
\hline
\end{tabular}

Key: C, carbon; Mn, manganese; P, phosphorus; S, sulfur; Si, silicon.

Note: Data are for product, not heat, analysis. Mechanical property requirements are identical between versions.

Perimeter columns were bolted via the butt plates to those immediately above and below, with four bolts in the upper stories and six bolts in the lower stories. Other than at the mechanical floors, panels were staggered (Fig. 2-4) so that only one-third of the units were spliced in any one story. At the mechanical floors, every column contained a splice, and columns were welded together as well as bolted.

Seats for the trusses that supported the floor were welded to spandrels in the perimeter column panels and to channels or core columns at the central core. The trusses were positioned on the seats and held in place with construction bolts until welded to the seats. The construction bolts generally remained in place after welding.

\subsubsection{Construction (On-site Assembly)}

During fabrication, Karl Koch Erecting Co. used a combination of bolting, shielded metal arc welding (E7018), and gas metal arc welding (semiautomatic Fab Co 71 with $\mathrm{CO}_{2}$ shielding) to join the components (Welding Design 1970b). The E70 8 low-hydrogen shielded metal arc (SMA) electrode would likely have been produced to ASTM Standard A 233-64T (also published by AWS as A 5.1-64T), then AWS Standard A 5.1-69 for the later parts of the fabrication. The 3/32 in. (2.4 mm) diameter Fab Co 71 (sic, probably should be FabCO 71, a trademark of Hobart Brothers Company) was an E70T-1 FCA electrode and would likely have been produced according to ASTM A 559 (withdrawn in 1969), then AWS A5.20-69. Higher-strength SMA electrodes (ASTM A 316 until 1969, then AWS A 5.5-69) were also permitted by the contract. More than $48,000 \mathrm{lb}(22,000 \mathrm{~kg})$ of electrodes were used in each of the towers (Welding Design 1970b). Koch used a combination of visual and ultrasonic inspection on the joints. They estimated that rework would cost three times as much as the original weld, so they inspected early and often to minimize any rework. One reason that rework was so expensive is that some welds took as many as 200 passes, so they wanted to catch any problems before the later passes made access more difficult.

Perhaps the most common construction standard for buildings of the period was AWS D 1.0 "Welding in Building Construction"(Fenton 1966). This document was subject to frequent revisions by the responsible committee. Some versions that may have been specified for parts of the WTC towers were the versions published in 1966, 1967, and 1968. The 1967 and 1968 revisions addressed issucs such as the details on the use of multiple-electrode submerged are welding, more requirements on qualification of 
the welders (especially tack welders), and the addition of radiographic inspection. Many of thesc revisions may have been driven by the needs of the WTC design. Since the D2.0 code refercnced in the discussion on fabrication of perimeter column panels above only covers the use of submerged arc and shielded metal arc welds (unless through special application of Section 5), use of D1.0 (spccifically through the use of Section 502) might have been the easiest way to cover the use of FabCO 71 electrode.

Incidentally, the apparent misspelling of FabCO 71 in one of the refercnces points out the problem of inconsistencies in some of the references. The likely explanations include both faulty memories of some details, but also changes that occurred after an article (perhaps based on the near-term construction plans) went to press. An apparent example of the later case involves the plan to use elcctroslag welding to fabricate the "trees," the branching columns that formed the transition from the $10 \mathrm{ft}(3 \mathrm{~m})$ spacing of columns in the lobby area to the $40 \mathrm{in.}(1 \mathrm{~m})$ spacing of columns for all the upper floors. Gillespie's book (1999) describes the fabrication of these trees by electroslag welding. However, Koch's book (2002) describes their inability to get the electroslag process operating under field conditions (in a location described as the "belly band," halfway up between the front doors and the branching of the trees). so they welded all these large joints manually.

Examination of the perimeter columns shipped to NIST revealed arc welds at the ends of the trusses, where they were attached to the columns during erection. These welds supplemented the bolt attachment at the seats, and were probably produced by gas metal arc or shielded metal arc electrodes. 
This page intentionally left blank. 


\section{Chapter 5 \\ REFERENCES}

\subsection{REFERENCES FROM PUBLICLY AVAILABLE SOURCES}

This section lists references from the open literature, primarily magazine and journal articles and books.

Alloy Digest. 1965. WEL-TEN 100N. Serial \#826.

Alloy Digest. 1967. WEL-TEN 50. Serial \#966.

Alloy Digest. 1968. WEL-TEN 60-LT. Serial \#1003.

Alloy Digest. 1969. WEL-TEN 80C-LT. Serial \#1061.

Alloy Digest. 1970. Bethlehem V Steel. Filing Code SA-257.

Alpsten, G. A. 1975. Variations in mechanical and cross-sectional properties of stcel. In Tall Building Criteria and Loading vol. $1 \mathrm{~b}$ of Planning and design of tall buildings. Edited by Thomas C.

Kavanagh et al. New York: American Society of Civil Engineers. 755-805.

American Institute of Steel Construction (AISC) 1974. The Variation of Product Analysis and Tensile Properties Carbon Steel Plates and Wide Flange Shapes. Contributions to the Metallurgy of Steel $1-120$.

American Institute of Steel Construction (AISC). 1973. Manual of Steel Construction. New York: American Institute of Steel Construction.

American Institute of Steel Construction (AISC). 1972. Standard specifications and load tables for open web steel joists, longspan steel joists, deep longspan steel joists. New York: Amcrican Institute of Steel Construction.

American Wclding Society (AWS). 1965. Tentative specification for bare mild steel electrodes and fluxes for submerged-arc welding. New York: American Welding Society and American Society for Testing and Materials.

American Welding Society (AWS). 1966. Specifications for welded highway and railway bridges. New York: American Welding Society.

American Welding Society (AWS) Structural Welding Committee. 1967. Addenda to D1.0-66 code for welding in building construction on and SRI-65 gas metal-arc welding with carbon dioxide shielding. New York: American Welding Society.

American Welding Socicty (AWS) Structural Welding Committee. 1968. Supplement to AWS D1.0-66, Code for welding in building construction, and AWS D2.0-66. Specifications for welded highway and 
railway bridges, on requirenents for submerged arc welding with multiple electrodes. New York: American Welding Society.

American Welding Society (AWS). Committee on Filler Metal. 1969. Specification for bare mild steel electrodes and fluxes for submerged-arc welding. New York: American Welding Society.

Brockenbrough, R. L. and B. G. Johnston. 1968. The structural steels and their mechanical properties. Chap. 1 in USS Steel Design Manual. Pittsburgh: United States Steel Corporation.

Civil Engineering-ASCE. 1970. World Trade Center shows on New York City skyline, 40:81.

Engineering News Record (ENR). 1967. Steel Ahoy! November 11.

Engineering News Record (ENR). 1972. The World Trade Center its planning, finance, design and construction as reported throngh the weeks for more than a decade. New York:McGraw-Hill

Feld, L. S. 1971. Superstructure for the 1,350-ft World Trade Center. Civil Engineering-ASCE. 41:6670.

Fenton, Edward A. 1966. Code for welding in building construction. New York: American Welding Society.

Gillespie, Angus Kress. 1999. Twin towers: the life of New York City's World Trade Center. New York: New American Library.

Goda, S., T. Ito, H. Gondo, I. Kimura, and J. Okamoto. 1964. Present status of weldable high strength steel, Yawata Technical Report (Yawata Seitetsu Kenkyı) 248:5086-5163.

Groner, Alex. 1981. PACCAR The pursuit of quality, Bellevue, WA: Documentary Book Publishers.

International Technical Information Institute. 1974. Handbook of Comparative World Steel Standards, Tokyo.

Irving, R. R. 1968. Construction, a materials arena. The Iton Age November 1:59-66.

Ito, T., K. Moriyama, and Y. Sogo. 1965a. Usability of WEL-TEN 80C welded joints of high-tension steel (in English). Yawata Technical Report (Yawata Seitetsu Kenkyu). 253:6307-6316.

Ito, T., K. Moriyama, and Y. Sogo. 1965b. Usability of WEL-TEN 80C Welded Joints of high-tension steel (In Japanese). Yawata Technical Report (Yawata Seitetsu Kenkyu). 253 6232-6244 (1965).

Japan's Iron and Steel Industry. 1968. New products and processes. In Japan's Iron and Steel Industry 1968 edition, edited by Sukeyuki Kawata. Tokyo: Kawata Publicity, Inc.

Koch, Karl and Richard Firstman. 2002. Men of steel: the story of the family that built the World Trade Center. New York: Crown Publishers. 
McAllister, T., ed. 2002. World Trade Center Building Performance Study: Data Collection, Preliminary Observations, and Recommendations. FEMA 403. Federal Emergency Management Agency. Washington, DC, May.

Otani, M. 1966. Fundamental properties of high tension steel (in Japanese). Yawata Technical Report (Yavata Seitetsu Kenhyu). 257:7066-7117.

Rodengen, Jeffrey L. 2000. The Legend of Trinity: Fort Lauderdale, Fl: Write Stuff Enterprises.

Somers, Robert E. and Theodore V. Galambos. 1980. Welding of Open Web Steel Joists. Technical Digest No. 8. Steel Joist Institute Richmond, VA. Based on inclusion of statistics on U.S. joist production in 1979 .

Stanray Corp. 1970. 1969 Annual Report.

Stanray Corp. 1971. 1970 Annual Report.

Welding Design and Fabrication. 1970a. Welding and fabricating 55,000 tons of steel for the World Trade Center, July:50-52.

Welding Design and Fabrication. 1970b. Welding and inspecting the World Trade Center-giant among giants, February:53-56.

Woldman's Engineering Alloys. 1990. Materials Park, OH: ASM International.

Zaizen, T. K.Moriyama, and M.Kawshima. 1968. On the Yawata's structural steel plates for low temperature applications. Yawata Technical Report (Yawata Seitetsu Kenkyu). 262:8239-8250.

\subsection{PRIVATE COMMUNICATIONS}

The text denotes with the symbol $\uparrow$ references that are private communications or unpublished works, but that are not bound by any material transfer agreement. All contemporaneous memoranda referring to Laclede are from the Laclede archives in Alton, Il. NIST obtained Yawata documents from Nippon Steel USA, New York office.

Bangert, D. 2002. Telephone interview with William Luecke. Confirmation that PACCAR has no records of the WTC contract. Structural steel division was sold "years ago." October 21.

Bay, R. D. 1968. Memorandum No. 11, Laclede internal memorandum showing grades of steel for bar joists, February 28.

Brown, Dale. 2002. Telephone interview with Richard Fields. Brown, the Laclede metallurgist during the WTC construction, confirmed that for ASTM A 36, Laclede would have specified a microalloyed steel similar to current ASTM A 572. November 20.

Christensen, Linda (VP and General Counsel, Tishman Construction). 2003. Letter to William Luecke. Tishman has retained no records from the World Trade Center construction, in response to letter sent on 19 February. April. 2 
Davis, William. 2002. Telephone interview with William Luecke. Montague Betts furnished rolled beams for the core of both towers as well as the antenna base for one tower. He remembered about 60 percent of the steel was American, and the rest was Japanese or British. Confirmed that they did buy steel from Yawata, and that Yawata had better tolerances than the US steel mills did. All records of the job were destroyed after 6 years. Montague Betts closed its steel operations in 1992. November 5.

Franconeri, Rich. 2003. Letter to William Luecke. SGS U.S. Testing Company was unable to locate any records relevant to the World Trade Center. April 25.

Garland, Janet. 2004. Electronic mail to William Luecke. Mitsui and Co. USA, New York office. confirms that they have no records relevant to steel imported for the World Trade Center. January 20.

Kamper, H. G. 1968. Internal Laclede memo to R. D. Bay shows chemistry and yield strength for A 242 steel. August 8.

Laclede Steel. 1968. Standard Resistance and Arc Weld Connections used in Truss Manufacture. February 28.

Magnusson, Jon D. 2002. Letter to William Luecke. Skilling Ward Magnussen Barkshire (the current name of SHCR) has "absolutely no documents relating to the WTC at our firm here in Seattle." November 12.

McKnight, M.E. 2003. Telephone interview with William Luecke. January 21.

Steinberg, P. 2002. Electronic mail to William Luecke. Steinberg worked for Crest Steel in the 1960s, which supplied steel to Stanray Pacific. They have no records from that era. December 26

Symes, R.C. 2002. Telephone interview with William Luecke. PC\&F made a serious effort to follow the $5 \mathrm{ksi}$ yield stress increments as noted in the plans. December 20.

Tarkan, Y.N. 2002 Telephone interview with William Luecke. Tarkan was chief engineer for Stanray Pacific. He remembered that all the steel for Stanray's contract came from Japan. When questioned about the Crest Steel note in the LERA documents, he thought that Crest might have been the distributor for that Japanese mill (Nippon Kokan). December 17.

Wall, Tony. 2002. Telephone interview with William Luecke. Former president of Dovell Engineering is in no position to provide details of the World Trade Center construction. December 3.

White, James. 2003. Telephone interview with William Luecke. PC\&F used (in addition to Yawata) U.S.S. and Bethlehem Steel for plates (probably for $F_{y}$ less than $60 \mathrm{ksi}$ ). February 11.

White, James. 1969b. Memo from SHCR to R.D. Bay (Laclede), returning mill test reports for A 242 steel. Laclede Steel Archives December 29.

Yaegashi, Tadashi 2003 Letter to William Luecke. Marubeni-Itochu Steel America confirms that they have no records relating to steel imported for the World Trade Center. February 7. 
Yawata Iron and Steel Co. Ltd. 1969. New York World Trade Center Building. Internal Yawata document.

Yawata Iron and Steel Co. Ltd. 1969b. WEL-TEN 80. Data sheets for WEL-TEN 80 steel.

\subsection{REFERENCES FROM NONPUBLIC SOURCES}

The text denotes with the symbol $\S$ references that are private communications or unpublished works bound by material transfer agreements.

Barkshire, Art. 1968a. Internal SHCR report to J. White on fabrication at PC\&F. Contains 5 page attachment showing instances of U.S.S. steel used in columns mostly in floors 20 to 30 Tower not specified 7 pages. May 15.

Barkshire, Art. 1968b. Internal SHCR to J. White showing spandrel plate of Kaisaloy 50-SG in panel 203-16-19A. 6 pages. December 4.

Barkshire, Art. 1968c. Internal SHCR memo to J. White stating that USS and Kaiser are being phased out as suppliers with Bethlehem (Seattle) and Japanese mills furnishing all steel. 2 pages with 5 pages attached. June 5 .

Barkshire, Art. 1969. Corner Panel Stiffener Plates Memo to R Symes (PC\&F) approving substitution of steel. Contains three Yawata mill reports. 6 pages. January 23.

Chauner, Richard, 1967a. Internal SHCR memo to James White. October 27.

Chauner, Richard, 1967b. Internal SHCR memo to James White. November 10.

Clarkson, William W. 1967. Memo from Montague-Betts Steel to R.M. Monti (PONYA) requesting permission to have Yawata supply steel similar to ASTM A 441-modified but with 0.2 percent to 0.4 percent mass fraction $\mathrm{Ni}$, to avoid the US Steel patent on the A 441 -modified composition. October 9 .

Equivalent Carbon Contents. 1967. Worksheet that calculates equivalent carbon content for various steels. It indicates that steel would be supplied in $5 \mathrm{ksi}$ intervals. Chemistries correspond to "Yawata Proposition." June 23.

Feld, Lester S. 1967. Internal PONYA memo to H. Tessler summarizing meeting between PC\&F, Koch, Tishman, SHCR, and PONYA to discuss engineering changes. Discusses spandrel plate splices, A 325 bolts, not using A 490 bolts for the spandrel splices, and a statement by N. Soldano (PC\&F) that Yawata would furnish imported steel with $F_{y}>36 \mathrm{ksi}$, and Kawasaki would furnish $36 \mathrm{ksi}$ steel. 5 pages. May 9.

Gallagher, H.B. 1968. Internal PONYA memo W. Borland detailing inspection trip to Great Britain to visit Colvilles mills at Motherwell and Mossend, and Dorman-Long. May 15.

Gallagher, Hugh. 1967. Internal PONYA memo to D. Brown. December 11. 
Goode, Bob. 1967. Internal SHCR memo to Leslie Robertson on Worthington, Skilling, Helle, Jackson letterhead stating that Dorman-Long will produce 1,200 $\mathrm{t}$ of wide flange (WF) sections for MontagueBetts. September 8.

Monti, R.M. 1967a. Letter from PONYA to R.C. Symes (PC\&F) mentioning discrepancies between purchase orders and inspection reports for Kawasaki steel plates. August 21.

Monti, R.M. 1967b. Memo to R. Morris (Stanray Pacific). November 13.

Morris, R.E. 1969. Letter to James White (SHCR) with attached mill test report for Fuji Steel Plate that appears in other documents. September 10.

Morris, R.E. 1967. Letter from Stanray Pacific to R.M. Monti (PONYA) showing Colvilles (British Steel Export Assn.) and Fuji Steel as source of plate for contract. September 8.

Port of New York Authority (PONYA). 1967. The World Trade Center Contract WTC-214.00 Fabricated Steel Exterior Wall $9^{\text {th }}$ Story Splice to Roof North and South Tower. This contract was between PONYA and PC\&F, but the materials chapters of the Laclede (WTC 221, Laclede) contract are identical. February 25.

Port of New York Authority (PONYA). 1967. The World Trade Center Contract WTC-214.00 Fabricated Steel Exterior Wall $9^{\text {th }}$ Story Splice to Roof North and South Tower. Clause 1 of the contract between PONYA and PC\&F defines the term Engineer (who was responsible for approving proprietary steels) as follows. "“Engineer' shall mean the Chief of the Planning and Construction Division of the World Trade Center of the World Trade Department of the Authority for the time being, or his successor in duties, acting personally or through his authorized representative, except where provided herein to be acting personally, who is at present the Construction Manager of the World Trade Center." February 25.

Port of New York Authority (PONYA). 1967. Change slip DM-116 to Stanray Pacific. June 6.

Skilling, Helle, Christiansen and Robertson (SHCR). 1967. World Trade Center Structural Drawing Books.

Symes, R.C. 1969a. Memo from PC\&F to M Gerstman (Tishman) requesting adjustment to payment because of steel changes. States that plates 1, 2, and 4 (flange, outside web, and spandrel) were made from imported steel (presumably Yawata) and plate 3 (inside web) was fabricated from domestic steel. Also contains a table showing tons of steel used by grade and thickness. 6 pages PCF\#T-40. February 5.

Symes, R.C. 1969b. Memo PC\&F to R.M. Monti (PONYA) requesting approval for material substitution, contains $F_{y}=45 \mathrm{ksi}$ and $F_{y}=50 \mathrm{ksiY}$ awata mill reports. February 24.

Symes, R.C. 1967a. Memo from PC\&F to R Monti (PONYA) requesting approval of Bethlehem $\mathrm{V}$-series steels outside of the published plate sizes. 2 pages. Denied without full information on September 8, 1967, requested again with further documentation on November 2, 1967. Provisionally approved November 18, 1967 (no PCF letter \#). August 14. 
Symes, R.C. 1967b. Letter PC\&F to R Monti (PONYA) requesting approval to use modified Bethlehem $\mathrm{V}$-series steels outside the published thickness rangc, with full specifications attached. (PCF \#66639) 7 pages Approved November 30, 1967. November 2.

Symes, R.C. 1967c. Memo from PC\&F to R.M. Monti (PONYA) including Yawata data sheets. June 6.

Tarkan, Y.N. 1969. Memo from Stanray Pacific to James White (SHCR) requesting approval for use of a welded plate. Includes mill sheet showing that the plate originated from Nippon Kokan Steel Fukuyama Works and was supplied by Crest Steel. August 12.

Walton, W.E. 1968. Letter to Malcolm Levy (PONYA) with attached ultrasonic and metallurgical report (Magnaflux Corp) on plate of "British" (i.e., Colvilles) steel. Details chemical analysis, weld quality and (poor-quality) micrographs. February 8.

Warner, H.L. 1967. Memo from Stanray Pacific to Malcolm Levy (PONYA) detailing distribution of plate thicknesses between British and Japanese steels. Total is 32000 tons. July 7.

White, James. 1969a. Memo from SHCR to R. Monti (PONYA) documenting use of heat-treated steel above (PC\&F) and below (PDM) the 9th floor splice. Contains statement that plate 3 (inside web) was fabricated from domestic steel, while plates 1, 2, and 4 (flange, outside web, and spandrel) are imported steel. Also contains table that shows where ASTM 441-modified and WEL-TEN grades were used, by thickness and yield strength. 28 pagcs. July 28.

White, James. 1969c. Memo approving the April 4, 1969 PC\&F steel substitutions. Has WEL-TEN 62 mill report. May 2.

White. James. 1968a. Memo from SHCR to RM Monti (Port Authority) approving PC\&F substitution of $F_{y}=100 \mathrm{ksi}$ steel for $F_{y}=90 \mathrm{ksi}$ steel in exterior columns. February 15.

White, James. 1968b. Memo from SHCR to R.M. Monti (Port Authority) approving use of Bcthlehem V60, V65, and V75 steels as specified for PC\&F. January 4.

White, James. 1967a. Memo from SHCR to R.M. Monti (PONYA) asking for clarification on origin of Japanese $36 \mathrm{ksi}$ steel (Yawata or Kawasaki). 2 pages. September 6.

White, James. 1967b. Memo from SHCR to R.M. Monti (PONYA) approving Ni-containing A 441-modified steel. Has two-page specification for Yawata A 441-modificd. October 18.

White, James. 1967c. Memo to PONYA. September 1.

Yamada, H. 1967. Memo from Marubeni-Iida, the firm that imported the Fuji steel for Stanray Pacific, to PONYA, listing 1,441 tons of A 36 and A 572 grade 42 steel plates up to 3 in. thick. Plates are $36 \mathrm{ft} 3 / 4 \mathrm{in}$. long and $36 \mathrm{in}$. to $945 / 8$ in wide. July 18. 
This page intentionally left blank. 


\section{Appendix A \\ Steel Companies InVOLVed IN THE WorLd TRADE CEnTER}

Most of the fabrication firms that worked on the steel for the World Trade Center (WTC) are no longer in business. This section summarizes the contributions of each of the major steel firms involved, and their current status.

\section{A.1 ATLAS MACHINE AND IRON WORKS}

Contract WTC212.

Atlas fabricated the $27 \mathrm{in.}$ by $32 \mathrm{in}$. perimeter box columns, spandrels, and X-bracing below the 4th floor (Feld 1971) (13.600 tons). This contract was the first major use of electroslag welding in the United States (Feld 1971).

Most recent address:

Atlas Machine and Iron Works

13951 Lee Highway

Gainesville, VA 22065

Arthur X. Miles, President and Registered Agent

The Virginia Corporation Commission indicates that Atlas went out of business in 1999. The address is at the intersection of US29 and I-66 in Gainesville, Virginia. A drive past the site on November 24, 2002, confirmed that it is inactive.

\section{A.2 DRIER STRUCTURAL STEEL}

Drier fabricated the foundation load distribution system (base plates and grillages) (Feld 1971). No information is available on its current status.

\section{A.3 DOVELL ENGINEERING}

Dovell was the detailer for Stanray Pacific. (The detailer makes the detailed engineering drawings of the columns and beams.)

Current address:

9901 Paramount Blvd, Suite 202

Downey, CA 90241

$562-927-4770$

Dovell President, Tony Wall (Wall $2002 \dagger$ ), indicated that the former owner, who was active in the WTC project, is not in a position to provide details of the WTC project.

\section{A.4 GRANITE CITY STEEL}

Granite City fabricated the electrical/telephone ducts and the floor deck system (Feld 1971). 


\section{A.5 HOBART BROTHERS CO./ITW}

Hobart provided the electrodes used for on-site erection by Karl Koch Erecting Company.

ITW purchascd it scveral years ago, but it still maintains its headquarters in Ohio.

Current address:

400 Trade Square East

Troy, $\mathrm{OH} 45373$

www.hobartbrothers.com

\section{A.6 KARL KOCH ERECTING COMPANY}

Koch erected the towcrs (McAllister 2002).

Skanska, an international construction company, purchased Koch in 1982. Karl Koch III wrote a book "Mcn of Steel" that includes information about the project (Koch 2002).

\section{A.7 LACLEDE STEEL CO.}

\section{Contract WTC226.}

Laclede fabricated the trusses for the floor system (Feld 1971). It entered bankruptcy on November 30, 1998, but re-emerged in January 2001 only to reenter bankruptcy again July 27, 2001. At the time of the NIST WTC Investigation, a group of former employees had purchased the assets.

Current address:

$211 \mathrm{~N}$ Broadway

St Louis, MO 63102

314-425-1400

\section{A.8 LEVINSON STEEL}

Contract WTC230.

Levinson fabricated the below-grade area (12,000 tons of 14WF sections), the plaza, and the damping units (Feld 1971). Metals USA acquired Levinson in March 1998. The www.metalsusa.com web site docs not list any information on Levinson, however. Metals USA went bankrupt in August 2001, but was reported to be emerging from bankruptcy on October 31, 2002.

\section{A.9 MONTAGUE-BETTS}

Contract WTC226.

Montague-Betts fabricated all the rolled columns and beams in the core of both towers, 25,900 tons (Feld 1971). Their contract was for "all rolled columns and beams, including cover-plated sections throughout both towers...including horizontal trusses on 2 nd floor.. and exterior wall steel above 107 th floor and the weldments for supporting future T.V. masts." (Feld 1971). 
Current address of former owners:

1619 Wythe Rd

PO Box 11929

Lynchburg. VA 24501

William Davis, President

434-522-3200

William Davis (2002 $\dagger$ ), son of the founder, confirmed that they furnished all the rolled beams for the core of both towers as well as the antenna base. Montague-Betts closed its steel fabrication busincss in 1992, though the family still owns a majority interest in one steel fabrication business in Lynchburg.

\section{A.10 MOSHER STEEL}

Mosher fabricated the elevator core framing system to the 9 th floor (Feld 1971) (13,000 tons).

Trinity Industries acquired Mosher Steel in November 1973, which is still in business. Rodengen's $(2000$, p. 58) book has only a partial chapter on Mosher, and only notes that it "shipped more than 13,000 tons of steel for the lower portion..."

\section{A.11 PACIFIC CAR AND FOUNDRY}

\section{Contract WTC214.}

Pacific Car and Foundry fabricated the perimeter column panels from the 9th to 107th floors (Fcld 1971), 55,800 tons. It changed its name to PACCAR in 1972. As PACCAR, thcy manufacture Kenworth and Peterbilt trucks.

Current address:

PACCAR Inc.

777 106th Avenue N.E.

Bellevue, WA 98004

Telephone 425-468-7400, Fax 425-468-8216

Dick Bangert (2002 †) (VP for facilities) confirmed that PACCAR sold the structural steel division "years ago" and has no records from that business. Ron Symes (2002 †), chief enginecr for PC\&F during the WTC construction, confirmed that the division was sold in 1974. The PACCAR corporate history (Groner 1981) reports that the WTC contract was not profitable for the Structural Steel Division because it had estimated the job based on shipping the completed sections by barge to New York, but were unable to obtain insurance to do that. As a result, they had to ship by rail, which nearly doubled the shipping costs. These losses, plus concessions to settle strikes in 1969 and 1970, scnt the division into a decline from which it never recovered. Nicholas Soldano $(2002 \dagger)$, former general manager, remembered that the metals recycler Schnitzer bought the Seattle property where the perimeter columns were fabricated.

\section{A.12 PITTSBURGH-DES MOINES STEEL}

Pittsburgh-Des Moines (PDM) fabricated the perimeter bifurcation columns from the 4th to 9th floors, 6,800 tons (Feld 1971). The bifurcation columns are also referred to as the "tuning forks" or the trees. Civil Engineering (1970) reported that Lukens Steel "supplied seven basic grades of carbon and alloy 
plate steels for use in the welded 'trees... steels meet yield strength requirements from 36,000 to 65,000 min psi." Reliance Steel and Aluminum (www.rsac.com) acquired PDM Steel Service Centers in July 2001.

\section{A.13 STANRAY PACIFIC CORP}

Stanray Pacific fabricated the welded core box columns and built-up beams above the 9th floor, 31,100 tons (Feld 1971).

The California business portal report indicates that the company is no longer in business (Record \# C0388500). According to its annual reports, the parent corporation, Stanray $(1969,1970)$, decided to close the Stanray Pacific (based in Los Angelcs, California) subsidiary during 1969. This was confirmed by Joe Tarkan, Stanray Pacific chief engineer for the WTC contract (Tarkan $2002 \dagger$ ). 


\section{Appendix B \\ NOTES ON ASTM STANDARDS FOR STRUCTURAL STEEL}

This appendix summarizes the important aspects of the relevant standards that governed the structural steel supplied and compares contemporary (current) and contemporaneous (1960s) standards. In general, the differences between the contemporaneous and contemporary standards are minor, and are usually additions or deletions of individual steel chemistries or small changes in test protocol. However, because of these changes, it is possible that a steel that met a construction-era version of a standard might not meet that same standard today, because the chemistry or elongation requirements have changed. This statement should not be interpreted to mean that the steel in question as used was unsuitable, however.

The ASTM International (ASTM) defines a standard as "a document that has been developed and established with the consensus principles of the Society and that meets the approval requirement of ASTM procedures and regulations." A standard may be a document that specifies the properties of a material, as in the case of steel standard specifications such as A 36. Other standards are test methods that define the way in which the properties in a specification must be measured. An example of this is A 370, which defines the test methods for establishing the strength of steel. An important aspect of ASTM standards is that they are consensus documents, established by committees where membership is open to all individuals and organizations. Except for military construction, the United States government does not establish structural steel standards for the industry. Instead, the ASTM committees that establish steel standards typically have members from both the producing and consuming segments of the industry. The standards they produce allow the producers and consumers to efficiently specify materials, without requiring them to include all possible properties and methods in a contract. This report, to avoid confusion with other uses, will use the term "standard" to refer to all ASTM documents, regardless of their status as Specifications, Test Methods, Terminology Standards, or Practices.

ASTM issues its standards annually in a multi-volume "Annual Book of ASTM Standards," but reviscs an individual standard only when the committee in charge sees a need. ASTM does require that standards be reauthorized every five years, even if they have not been revised. The designation of a standard, for example A 36-66, comprises two parts. The first (for example "A 36") is a shorthand for the general chemistry and mechanical property requirements, in the case of structural steels. Following the designation is a two digit number denoting the most recent revision year of the standard (for example "66 ," which denotes a substantial revision in 1966). The steel fabrication contracts stipulated that the appropriate standards were those in effect in September 1966. In some cases the relevant standard was not revised in 1966, and so bears a prior year revision mark.

An individual ASTM standard does not contain all the information to uniquely characterize the steel. Instead, there is a "chain of standards" that defines the properties of the steel. The World Trade Center (WTC) steel contracts allowed the use of steels that conformed to certain ASTM standards (e.g., A 36, A 242 A 441, A 514). These standards define the mechanical and chemical properties of the steels, but in turn reference other standards that define how those properties shall be measured. For instance, all the steel standards, then and now, require that the steel conform to ASTM A 6 ("Requirements for Delivery of Structural Steel"), which specifies the dimensional tolerances of plates 
and rolled shapes. Additionally, A 6 requires that mechanical property tests shall be conducted in accordance with ASTM A 370 ("Standard Methods and Definitions for Mechanical Testing of Steel Products"). Although ASTM A 370 refers to ASTM E 8 ("Test Methods for Tension Testing of Metallic Materials") in general, it specifically restricts the test mcthods for establishing the properties of structural steel products. The important restrictions on test technique for structural steel are in A 370, and not in E 8 .

As an example, the chain of standards for A 36 steel is

\begin{tabular}{|c|c|c|c|c|c|c|}
\hline A 36 & $\rightarrow$ & A 6 & $\rightarrow$ & A 370 & $\rightarrow$ & E 6 \\
\hline $\begin{array}{l}\text { Chemistry and } \\
\text { mechanical } \\
\text { property } \\
\text { requirements }\end{array}$ & & $\begin{array}{l}\text { Tolerances for } \\
\text { delivery and } \\
\text { requirements for } \\
\text { determining } \\
\text { chemical and } \\
\text { mechanical } \\
\text { properties }\end{array}$ & & $\begin{array}{l}\text { Methods for } \\
\text { determining } \\
\text { mechanical } \\
\text { properties }\end{array}$ & & $\begin{array}{l}\text { Definitions of terms } \\
\text { for mechanical } \\
\text { properties }\end{array}$ \\
\hline
\end{tabular}

The rest of this appendix describes the minor differences between the ASTM standards that governed structural steel used for construction of the WTC, and those that exist today.

\section{B.1 A 6-65 VS. A 6-02}

ASTM A 6-65 "Standard Specification for General Requirements for Delivery of Rolled Steel Plates, Shapes, Sheet Piling and Bars for Structural Use," specifies the tolerances for structural steel. Most of A 6 is devoted to specifying the dimensional tolerances on finished steel products. Both versions specify that mechanical properties shall be determined in accord with A 370. At some point ASTM editorially amended the title of the standard to its present version "Standard Specification for General Requirements for Rolled Structural Steel Bars, Plates, Shapes, and Sheet Piling." A 6-02 is a much longer and more complex document than A 6-65.

For determining mechanical properties, A 6-65 specifies the size and shape of test specimens, while A 6-02 references (similar) specimens in A 370. Table B-1 summarizes the significant differences between A 6-65 and A 6-02. Two differences are particularly significant. A 6-65 specifies that steels shall be tested in the rolling direction (longitudinally), but A 6-02 requires most plates to be tested in the transverse direction. The location of specimens from shapes is also different: in A 6 they are always taken from the web, but in A 6-02 for the large shapes used for columns, the specimen is taken from the flange. Typically, bccause the flange is thicker than the web, the flange yield stress will be less than the web yield stress (Alpsten 1975, AISC 1974). In summary, to conform to A 6, most A 36 specimens would have been tested full thickness. Core column steels would have been permitted to use the round $0.5 \mathrm{in}$. $(12.7 \mathrm{~mm})$ diameter specimen because of their thickness. Thin perimeter column plates would have been tested full thickness. 
Table B-1. Differences in specimen sampling requirements between A 6-65 and A 6-02e.

\begin{tabular}{|c|c|c|c|}
\hline Shape & Specimen Location & Orientation & Specimen type and size \\
\hline \multicolumn{4}{|c|}{ A 6-65 } \\
\hline $\begin{array}{l}\text { Beams, channels or } \\
\text { zees }\end{array}$ & Web (Sec. 6.4) & $\begin{array}{l}\text { Longitudinal } \\
\text { (Sec. 6.3) } \\
\text { Full-thickness } \\
\text { (Sec. 6.5) }\end{array}$ & \\
\hline $\begin{array}{l}\text { Shapes or plates } \\
\text { except alloy steel } \\
\text { plates over } 1.5 \text { in. } \\
\text { thick }\end{array}$ & $\begin{array}{l}\text { Generally specified as } \\
\text { corner in product } \\
\text { specifications, but no } \\
\text { apparent restrictions on } \\
\text { position within } \\
\text { thickness for } \\
\text { non-full-thickness } \\
\text { specimens. }\end{array}$ & $\begin{array}{l}\text { Longitudinal } \\
\text { (Sec. 6.3) } \\
\text { Full-thickness } \\
\text { (Sec. 6.5) }\end{array}$ & $\begin{array}{l}18 \text { in. long specimen with } 8 \text { in. gage length } \\
\text { or straight-sided specimen. For }>1.5 \text { in. } \\
\text { can use } 0.505 \text { in. diameter round specimen } \\
\text { with } 2 \text { in. gage length }\end{array}$ \\
\hline $\begin{array}{l}\text { Alloy steel plates } \\
0.75<p<=1.5 \mathrm{in}\end{array}$ & “ & Longitudinal & $\begin{array}{l}\text { May use a round specimen with } \\
d=0.505 \text { in. very similar to A } 37002 \\
\text { Fig. } 4\end{array}$ \\
\hline $\begin{array}{l}\text { Alloy steel plates } \\
>1.5 \text { in. thick }\end{array}$ & “" & Longitudinal & $\begin{array}{l}\text { May use a round specimen with } \\
d=0.505 \text { in. very similar to A } 37002 \\
\text { Fig. } 4\end{array}$ \\
\hline \multicolumn{4}{|c|}{ A 6-02e } \\
\hline Shapes: $t \leq 0.75$ in. & $\begin{array}{l}\text { If } w>6 \text { in. from the } \\
\text { flange, otherwise from } \\
\text { the web (Sec. 11.3.2) }\end{array}$ & $\begin{array}{l}\text { Full thickness } \\
\text { (Sec. 11.5.1) } \\
\text { Longitudinal } \\
\text { (Sec. 11.2) }\end{array}$ & $\begin{array}{l}8 \text { in. or } 2 \text { in. gage length flat specimen } \\
\text { A } 370 \text { Fig. } 3\end{array}$ \\
\hline Shapes: $t>0.75 \mathrm{in}$. & “" & “" & $\begin{array}{l}0.5 \text { in. diameter round specimen (A } 370 \\
\text { Fig. 4) or full thickness flat specimen } \\
\text { (A } 370 \text { Fig. 3) if desired }\end{array}$ \\
\hline Plates: $t \leq 0.75 \mathrm{in}$. & Corner (Sec. 11.3.1) & $\begin{array}{l}\text { Full thickness } \\
\text { (Sec. } 11.5 .1 \text { ) } \\
\text { Transverse if } \\
w>24 \text { in. (Sec. } \\
11.2 \text { ) }\end{array}$ & $\begin{array}{l}8 \text { in. or } 2 \text { in. gage length specimen A } 370 \\
\text { Fig. } 3\end{array}$ \\
\hline Plates: $t>0.75$ in. & “ & “" & $\begin{array}{l}0.5 \text { in. diameter round specimen (A } 370 \\
\text { Fig. 4) or full thickness flat specimen } \\
\text { (A } 370 \text { Fig. 3) if desired }\end{array}$ \\
\hline
\end{tabular}

In terms of chemistry, A 6-65 does not require any special method be used to determine the chemistry of the steel. In contrast, A 6-02 specifies that chemistry is to be determined in accord with ASTM A 751 ("Standard Test Methods, Practices, and Terminology for Chemical Analysis of steel products"). The chemistry requirements have also been moved between standards. A 6-65 specifies two types of chemical analysis. The so-called ladle analysis is conducted at the steel mill. The end user may specify a "check" analysis of the finished product. All of the contemporaneous steel standards (e.g., A 36-66, etc) specify compositions determined in both ladle and check analyses, where the check analyses are slightly relaxed from the ladle analyses. In contemporary standards, the check analysis values (now called product analysis) have been removed from the standards to a single table in A 6-02. A spot check of the some of these for A 36-01 and A 242-01 indicates that the values listed in Table B of A 6-02 ("Permitted 
Variations in Product Analysis") are identical to the values listed under check analysis in the contemporaneous steel standards of the 1960s.

An interesting restriction of A 6-02 that is not explicitly stated in A6-66 is that there is no corresponding product analysis for mechanical properties. Effectively, once the mill has certified the heat of steel as conforming to the mechanical property requirements of the standard, the user must accept this. Any requirements for product analysis of mechanical properties are beyond the scope of the standard.

Formally, then, it is not possible to certify that a specimen taken from recovered WTC steel meets a given standard, because strength testing must take place at the mill. Conversely, should a specimen taken as part of the investigation exhibit a yield point or strength less than the applicable standard, this docs not imply that the steel as a whole did not meet the standard. A 6-02 makes this quite clear:

X2.1 The tension testing requirements of Spccification A $6 / \mathrm{A} 6 \mathrm{M}$ are
intended only to characterize the tensile propcrties of a heat of steel for
determination of conformance to the requirements of the material
specifications. These testing proccdures are not intended to define the
upper or lower limits of tensile properties at all possible test locations
within a heat of steel. It is well known and documented that tensile
properties will vary within a heat or individual piece of steel as a
function of chemical composition, processing, testing procedure and
other factors. It is, thercfore, incumbent on designers and engineers to
use sound engineering judgement (sic) when using tension test results
shown on mill test reports. The testing procedures of Specification
A $6 / \mathrm{A} 6 \mathrm{M}$ have been found to provide material adequate for normal
structural design criteria.

Thus, the results of contemporary tension tests on WTC steels can only be used to assert that the steel in question is of a quality that could reasonably be expected to meet a given ASTM standard. It may be that an individual tension test might result in a measured yield point less than that acceptable in the standard. As long as the measured yield point is close to the specified minimum, the steel in question probably met the requirements of the standard.

\section{B.2 A $370-67$ VS. A $370-02$}

ASTM A 370, "Standard Methods and Definitions for Mechanical Testing of Steel Products," controls the methods used for mill acceptance testing of heats (or plates) of steel. Aside from minor revisions in 1966, to incorporate A 443 ("Method of Notch Toughness of Turbine and Generator Steel Forgings") A 370-67 is identical to A $370-66$.

By and large A 370-67 and A 370-02 are very similar. Although the section numbers are different, much of the text is unchanged over the past 35 years. Table B-2 summarizes the important differences between the two documents as they relate to tensile testing. As long as the loading rates are specified as the maximum rate in A 370-02, the test results will also meet $\mathrm{A}$ 370-67. 
Table B-2. Differences between A 370-67 and A 370-02.

\begin{tabular}{|c|c|}
\hline A $370-67$ & A $370-02$ \\
\hline $\begin{array}{l}\text { Section } 10 \mathrm{~d} \text { suggests that tests defined in terms of } \\
\text { strain rate are acceptable, but not feasible with } \\
\text { production grade equipment }\end{array}$ & $\begin{array}{l}\text { Section 7.4. specifically allows tests defined in terms } \\
\text { of strain rate }\end{array}$ \\
\hline No such language. & Note 2 specifically disallows tests in load control \\
\hline No restriction on minimum extension rate for tests & $\begin{array}{l}\text { Section 7.4.1 requires that minimum speed for testing } \\
\text { shall not be less than one-tenth of the maximum rate } \\
\text { for determining yield point or yield stress }\end{array}$ \\
\hline No such language & $\begin{array}{l}\text { Allows maximum testing rate to be less than } 100,000 \\
\text { psi, min }\end{array}$ \\
\hline & $\begin{array}{l}\text { Section } 13 \text { (Determination of yield point) has different } \\
\text { language but is similar in spirit }\end{array}$ \\
\hline $\begin{array}{l}\text { Section } 12(b)(1) \text { specifies a so-called "divider method" } \\
\text { for measuring yield point. }\end{array}$ & Absent from Section 13 \\
\hline $\begin{array}{l}\text { In section } 13 \text { (determination of yield strength) the order } \\
\text { of the methods is reversed. }\end{array}$ & \\
\hline $\begin{array}{l}\text { In Section } 13 \text { the extension under load method may "be } \\
\text { used only when the product specification permits." }\end{array}$ & No such recommendation \\
\hline $\begin{array}{l}\text { Section } 13 \text { allows the yield point to be reported as the } \\
\text { yield strength if the load drop occurs before the } \\
\text { specified offset is reached. }\end{array}$ & No such allowance \\
\hline $\begin{array}{l}\text { A Class B } 1 \text { extensometer is required for all offset } \\
\text { method determinations of yield strength. }\end{array}$ & $\begin{array}{l}\text { Section } 13.2 .2 \text { allows the use of a Class B2 } \\
\text { extensometer for determining yield strength if the } \\
\text { offset is } \leq 0.2 \%\end{array}$ \\
\hline
\end{tabular}

B.3

E 6-66 VS. E 6-99 22

ASTM E 6, "Standard Terminology Relating to Methods of Mechanical Testing," defincs the technical terms used in the various mechanical testing standards. The definitions of elastic limit, elongation, gauge length, Poisson's ratio, proportional limit, reduction of area, and tensile strength are word-for-word identical in the two standards. The definitions of yield point and yicld strength differ textually, but not in spirit. Table B-3 summarizes the textual differences betwcen the two versions.

All chemistry requirements of Table 2 are identical. A 36-66 requires the material to pass a bend test defined as "The bend test specimens shall stand bcing bent cold through 180 deg without cracking on the outside of the bent portion, to an inside diameter which shall have a relation to the thickness of the specimens as prescribed in Table IV." The bend test is abscnt from A 36-01. A 36-66 requires that the steel be made by "open-hearth, basic-oxygen, or electric-furnace" A 36-01 has no such requirements. The elongation requirements differ between the two standards. A 36-66 has relaxed elongation requirements for thicker plates that are missing from A 36-01, and does not differentiate between plates and shapes for elongation requirements. Other than these minor differences, the standards are identical. 
Table B-3. Differences in the definitions of yield point and yield stress in ASTM E 6.

\begin{tabular}{|c|c|}
\hline E 6-66 & E $6-99^{\varepsilon 2}$ \\
\hline \multicolumn{2}{|c|}{ Yield Point } \\
\hline $\begin{array}{l}\left.\text { "[FL }{ }^{-2}\right] \text { the first stress in a material, less than the } \\
\text { maximum attainable stress, a which an increase in } \\
\text { strain occurs without an increase in stress } \\
\text { Note-It should be noted that only materials that } \\
\text { exhibit the unique phenomenon of yielding have a } \\
\text { "yield point." }\end{array}$ & $\begin{array}{l}\text { "YP }\left[\mathrm{FL}^{-2}\right], \mathrm{n}-\text { a term used, by E } 8 \text { and E } 8 \mathrm{M} \text {, for the } \\
\text { property which is now referred to as upper yield } \\
\text { strength." } \\
\text { "Upper yield strength UYS, }\left[\mathrm{FL}^{-2}\right], \mathrm{n} \text {-in a uniaxial test, } \\
\text { the first stress maximum (stress at first zero slope) } \\
\text { associated with discontinuous yielding at or near the } \\
\text { onset of plastic deformation." }\end{array}$ \\
\hline \multicolumn{2}{|c|}{ Yield Strength } \\
\hline $\begin{array}{l}\left.\text { "[FL }{ }^{-2}\right] \text { The stress at which a material exhibits a } \\
\text { specified limiting deviation from the proportionality } \\
\text { of stress to strain. the deviation is expressed in terms } \\
\text { of strain." } \\
\text { Notes on the offset and total extension under load } \\
\text { methods follow. }\end{array}$ & $\begin{array}{l}\text { "YS or } \mathrm{S}_{\mathrm{y}}\left[\mathrm{FL}^{-2}\right], \mathrm{n} \text {-the engineering stress at which, by } \\
\text { convention, it is considered that plastic elongation of the } \\
\text { material has commenced. This stress may be specified } \\
\text { in terms of }(a) \text { a specified deviation from a linear } \\
\text { stress-strain relationship, }(b) \text { a specified total extension } \\
\text { attained, or }(c) \text { maximum or minimum engineering } \\
\text { stresses measured during discontinuous yielding." } \\
\text { Discussion of the offset and specified extension under } \\
\text { load methods follows, as well as discussion of upper and } \\
\text { lower yield strengths, differences between the results of } \\
\text { the two methods and of rate effects. }\end{array}$ \\
\hline
\end{tabular}

\section{B.5 A 242-66 VS. A 242-01}

The yield and tensile requirements are unchanged in the two standards, but the chemistry requirements differ substantially. A 242-66 admits high and low carbon variants. A 242-01 admits only a low carbon, low manganese type. During the WTC construction era, A 242 was revised to include the Type 1 variant of A 242-01. Table B-4 compares the chemistry requirements between the two standards. Another difference is that A 242-0 i prescribes the method for determining the atmospheric corrosion resistance, while A 242-66 only states, "If the steel is specified for materially greater atmospheric corrosion resistance than structural carbon steel with copper, the purchaser should so indicate and consult with the manufacturer." The clongation requirements are relaxed for thicker plates and shapes in A 242-66. The current standard also adds some required elongations when specimens with $2 \mathrm{in}$. gage length are tested. Finally, A 242-01 no longer mandates that steel pass a bend test. Requirements for bend testing are now included as a non-mandatory appendix in A 6-02.

The A 242 steel that Laclede supplied for the floor trusses would have met the chemistry requirements of A 242-66, but would not meet the chemistry requirements of A 242-01, because of its elevated carbon content. In terms of its load-carrying capacity, these differences are irrelevant, however. 
Table B-4. Differences in chemistry requirements between A 242-66 and A 242-01.

\begin{tabular}{|l|c|c|c|}
\hline \multicolumn{1}{|c|}{ Element } & A 242-66 & A 242-66 & $\begin{array}{c}\text { A 242-01 } \\
\text { (Type 1) }\end{array}$ \\
\hline C (max.) & 0.22 & 0.15 & 0.15 \\
\hline Mn (max.) & 1.25 & 1.4 & 1.00 \\
\hline S (max.) & 0.05 & 0.05 & 0.05 \\
\hline P (max.) & NR & NR & NR \\
\hline Cu (min.) & NR & NR & 0.20 \\
\hline
\end{tabular}

Key: C. carbon; $\mathrm{Cu}$, copper; $\mathrm{Mn}$, manganese; $\mathrm{NR}$, no requirement;

P. phosphorus; $\mathrm{S}$, sulfur.

Note: Compositions expressed in $\%$ mass fraction.

B.6

A $441-66$ VS. A 572.01

ASTM A 441 was withdrawn in 1989. A 441-66 and A 572-01 are similar in several ways. Both are standards for vanadium-containing steels with minimum yield points greater than those specified in A 36 . To some degree it can be argued that A 572 replaced A 441. The carbon, manganese, and silicon levels in both standards are similar but not identical. However, in terms of chemistry, most steels that met A 441-66 would probably meet A 572-01. A 572-01 admits a wider range of minimum yield points in much thicker sections as well, see Table B-5.

Table B-5. Differences between

A 441-66 and A 572-01.

\begin{tabular}{|c|c|c|}
\hline $\begin{array}{l}\text { A } 441-66 \\
\text { YP (ksi) }\end{array}$ & $\begin{array}{c}\text { Thickness } \\
\text { t (in.) }\end{array}$ & $\begin{array}{l}\text { A 572-01 } \\
\text { YP (ksi) }\end{array}$ \\
\hline \multirow[t]{2}{*}{40} & 4 in. $<t<=8$ in. & \\
\hline & $t<=6$ in. & 42 \\
\hline \multirow[t]{3}{*}{42} & 1.5 in. $<t<=4$ in. & \\
\hline & $t<=4$ in. & 50 \\
\hline & $t<=2$ in. & 55 \\
\hline \multirow[t]{3}{*}{46} & $3 / 4$ in. $<t<=1.5$ in. & \\
\hline & $t<=1.25$ in. & 60 \\
\hline & $t<=1.25 \mathrm{in}$. & 65 \\
\hline 50 & $r<=3 / 4$ in. & \\
\hline
\end{tabular}

\section{B.7 A 514-65 VS. A 514-00A}

A 514-65 differs from A 514-00a at dozens of points. Table B-6 summarizes the substantial ones.

Unlike standards such as A 36 , which have simple, non-proprietary chemistry requirements, each variant chemistry in A 514 represents a single mill's $100 \mathrm{ksi}$ steel. For instance, Brockenbrough and Johnson (1968) identify A 514 Grade F as USS T1, A 514 Grade B as USS T1 Type A, and A 514 Grade H as USS T1 Type B. 
Table B-6. Differences in ASTM A 514-65 and A 514-00a.

\begin{tabular}{|c|c|c|}
\hline & A 514-65 & A 514-00a \\
\hline $\begin{array}{l}\text { Sampling } \\
\text { requirements }\end{array}$ & $\begin{array}{l}\text { One tension test from each of two plates from } \\
\text { each lot (Sec. 10.2) } \\
\text { Brinell hardness from all plates not } \\
\text { tension-tested (Sec. } 7.1 \text { ) }\end{array}$ & $\begin{array}{l}\text { One tension test from every plate in each lot } \\
\text { (Sec. } 8.1 \text { ) } \\
\text { Brinell hardness may be substituted for plates } \\
3 / 8 \text { in. and under, with tension test from at } \\
\text { least two plates (Sec. } 7.2 \text { ) }\end{array}$ \\
\hline $\begin{array}{l}\text { Test specimen } \\
\text { orientation }\end{array}$ & No special requirement & $\begin{array}{l}\text { Plates over } 24 \text { in. wide must be tested in the } \\
\text { transverse direction }(8.1)\end{array}$ \\
\hline Strength & $\begin{array}{l}\quad t \leq 3 / 4 \text { in. } 115 \mathrm{ksi} \leq T S \leq 135 \mathrm{ksi} \\
3 / 4 \mathrm{in} .<t \leq 2.5 \mathrm{in.} 115 \mathrm{ksi} \leq T S \leq 135 \mathrm{ksi} \\
2.5 \mathrm{in.}<t \leq 4 \text { in. } \quad 105 \mathrm{ksi} \leq T S \leq 135 \mathrm{ksi} \\
\text { (Table 2) }\end{array}$ & $\begin{array}{l}\quad t \leq 3 / 4 \text { in. } \quad 110 \mathrm{ksi} \leq T S \leq 130 \mathrm{ksi} \\
3 / 4 \mathrm{in.}<t \leq 2.5 \mathrm{in.} 110 \mathrm{ksi} \leq T S \leq 130 \mathrm{ksi} \\
2.5 \mathrm{in} .<t \leq 6 \mathrm{in} . \quad 105 \mathrm{ksi} \leq T S \leq 130 \mathrm{ksi} \\
\text { (Table } 2 \text { ) }\end{array}$ \\
\hline $\begin{array}{l}\text { Elongation in } \\
2 \text { in. }(\%)\end{array}$ & $\begin{array}{l}2.5 \text { in. }<\mathrm{t} \leq 4 \text { in.: } 17 \% \\
\text { special elongation reduction allowances for } \\
\text { plates under } 5 / 16 \text { in. (Sec. } 6.2 \text { ) }\end{array}$ & $\begin{array}{l}2.5 \text { in. }<t \leq 6 \text { in.: } 16 \% \\
\text { No such allowance }\end{array}$ \\
\hline $\begin{array}{l}\text { Chemistry } \\
\text { (compositions } \\
\text { expressed in } \\
\% \text { mass } \\
\text { fraction) }\end{array}$ & $\begin{array}{l}\text { Admits Types D, G } \\
\text { Type D 0.13-0.2 } 0.4-0.7 \mathrm{Mn}, 0.035 \mathrm{P}, 0.04 \mathrm{~S} \\
0.2-0.35 \mathrm{Si}, 0.85-1.2 \mathrm{Cr}, 0.15-0.25 \mathrm{Mo} \\
0.04-0.1 \mathrm{Ti}, 0.2-0.4 \mathrm{Cu}, 0.0015-0.005 \mathrm{~B} \\
\text { Type G } 0.15-0.21 \mathrm{C}, 0.8-1.1 \mathrm{Mn}, 0.035 \mathrm{P} \\
0.04 \mathrm{~S}, 0.5-0.9 \mathrm{Si}, 0.5-0.9 \mathrm{Cr}, 0.4-0.6 \mathrm{Mo} \\
0.05-0.15 \mathrm{Zr}, 0.0025 \mathrm{Max} \mathrm{B}\end{array}$ & $\begin{array}{l}\text { Types D, G absent } \\
\text { Admits new types } \mathrm{J}, \mathrm{K}, \mathrm{M}, \mathrm{P}, \mathrm{Q}, \mathrm{R}, \mathrm{S}, \mathrm{T} \text {. }\end{array}$ \\
\hline Chemistry & Most $\mathrm{S}$ allowables are $0.04 \%$ & Most S allowables are $0.035 \%$ \\
\hline
\end{tabular}

\section{B.8 YIELD POINT VS. YIELD STRENGTH}

Both E 8 and A 370 distinguish between yield point and yield strength. For steels of interest to the investigation, all standards for steels with yield strength under $80 \mathrm{ksi}$, whether contemporary or contemporaneous, specify yield point instead of yield strength. ASTM E 6-99 $9^{\varepsilon 2}$ (Standard Terminology Relating to Methods of Mechanical Testing) defines them as follows:

- yield point, YP $\left[\mathrm{FL}^{-2}\right], \mathrm{n}$ - a term used, by E 8 and E $8 \mathrm{M}$, for the property which is now referred to as upper yield strength.

- upper yield strength, UYS, $\left[\mathrm{FL}^{-2}\right], \mathrm{n}$-in a uniaxial test, the first stress maximum (stress at first zero slope) associated with discontinuous yielding at or near the onset of plastic deformation.

- yield strength, YS or $S_{y}$ [FL-2], $\mathrm{n}$-the engineering stress at which, by convention, it is considered that plastic elongation of the material has commenced. This stress may be specified in terms of $(a)$ a specified deviation from linear stress-strain relationship, $(b)$ a specified total extension attained, or $(c)$ maximum or minimum engineering stresses measured during discontinuous yielding.

The definitions of yield point and yield strength differ textually, but not semantically, between ASTM E 6-99 $9^{\varepsilon 2}$ and E 6-66, and are contrasted in Sec. 0 and Table B-7. 
Table B-7. Methods for determining Yield Point and Yield Strength in ASTM A 370.

\begin{tabular}{|c|c|}
\hline A 370-67 & A $370-02$ \\
\hline \multicolumn{2}{|c|}{ Yield Point } \\
\hline $\begin{array}{l}\text { "Drop of the beam" method } \\
\text { Section } 12(\mathrm{a})(1)\end{array}$ & $\begin{array}{l}\text { "Drop of the beam" method } \\
\text { Section } 13.1 .1\end{array}$ \\
\hline $\begin{array}{l}\text { Position of the knee } \\
\text { Section } 12(a)(2)\end{array}$ & $\begin{array}{l}\text { Position of the knee } \\
\text { Section 13.1.2 }\end{array}$ \\
\hline $\begin{array}{l}\text { Total extension under load (at a suggested strain of } \\
\varepsilon=0.005) \\
\text { Section } 12(\mathrm{~b})(2)\end{array}$ & $\begin{array}{l}\text { Total extension under load (at a suggested strain of } \\
\varepsilon=0.005 \text { ) } \\
\text { Section } 13.1 .3\end{array}$ \\
\hline "Divider method" Section 12(b)(1) & \\
\hline \multicolumn{2}{|c|}{ Yield Strength } \\
\hline $\begin{array}{l}\text { Offset method with no suggested value but with an } \\
\text { example that uses } \varepsilon=0.002 \\
\text { Section } 13 \text { (b) }\end{array}$ & $\begin{array}{l}\text { Offset method with no suggested value but with an } \\
\text { example that uses } \varepsilon=0.002 \\
\text { Section } 13.2 .1\end{array}$ \\
\hline $\begin{array}{l}\text { Extension under load with no required or suggested } \\
\text { strain value: "this approximate method be used only } \\
\text { when the product specification permits" } \\
\text { Section } 13 \text { (a) }\end{array}$ & $\begin{array}{l}\text { Extension under load with no suggested strain, but with } \\
\text { an example that uses of } \varepsilon=0.005 \\
\text { Section } 13.2 .2\end{array}$ \\
\hline
\end{tabular}

In terms of mechanical properties, it matters little whether yield point or yicld strength is specified. Almost certainly the yield point of plain carbon steels (like A 440 and A 36) will exceed the yield strength by only $1 \mathrm{ksi}$ to $4 \mathrm{ksi}$, because they typically exhibit a yield drop after yiclding. Of the relevant standards, only A 514 specifies steel in terms of yield strength. Both contemporary and contemporaneous version of A 36, A 242, A 441, and A 572 specify yield point rather than yield strength. The American Institute of Steel Construction (AISC) Manual of Steel Construction (AISC 1973, p. 1-3) treats them identically:

As used in the AISC Specification, "yield stress" denotes either the specified minimum yield point (for those steels that have a yield point) or specified minimum yield strength (for those steels that do not have a yield point).

A 370-02 permits three different methods for measuring yield point and two methods for yield strength, summarized in Table B-2. The "drop of the beam" method applies to testing machines that prescribe the loading rate, rather than the extension rate.

Interestingly, neither A 370-67 nor A 370-02 mandates a specific value of the total extension under load determining either yield point or yield stress when using the total extension under load method. It does suggest a value of $\varepsilon=0.005$, but does so in a non-mandatory note. Furthermore, A 370-67 does not require the mill to report which method it used for measuring yield point. Neither A 6-65 nor A 370-67 has any requirements as to the contents of a mill report. A 6-02 does have a detailed section on Test Reports, however. 
This page intentionally left blank. 

